\title{
DISPONIBILIDADE DE NITROGÊNIO, ALTERAÇÕES NAS CARACTERÍSTICAS QUÍMICAS DO SOLO E DO MILHO PELA APLICAÇÃO DE EFLUENTE DE ESGOTO TRATADO
}

\section{ADRIEL FERREIRA DA FONSECA}

Dissertação apresentada à Escola Superior de Agricultura "Luiz de Queiroz", Universidade de São Paulo, para obtenção do título de Mestre em Agronomia, Área de Concentração: Solos e Nutrição de Plantas.

\section{PIRACICABA}

Estado de São Paulo - Brasil

Dezembro - 2001 


\title{
DISPONIBILIDADE DE NITROGÊNIO, ALTERAÇÕES NAS CARACTERÍSTICAS QUÍMICAS DO SOLO E DO MILHO PELA APLICAÇÃO DE EFLUENTE DE ESGOTO TRATADO
}

\author{
ADRIEL FERREIRA DA FONSECA \\ Engenheiro Agrônomo
}

Orientador: Prof. Dr. ADOLPHO JOSÉ MELFI

Dissertação apresentada à Escola Superior de Agricultura "Luiz de Queiroz", Universidade de São Paulo, para obtenção do título de Mestre em Agronomia, Área de Concentração: Solos e Nutrição de Plantas.

PIRACICABA

Estado de São Paulo - Brasil

Dezembro - 2001 
Dados Internacionais de Catalogação na Publicação (CIP) DIVISÃO DE BIBLIOTECA E DOCUMENTAÇÃO - ESALQ/USP

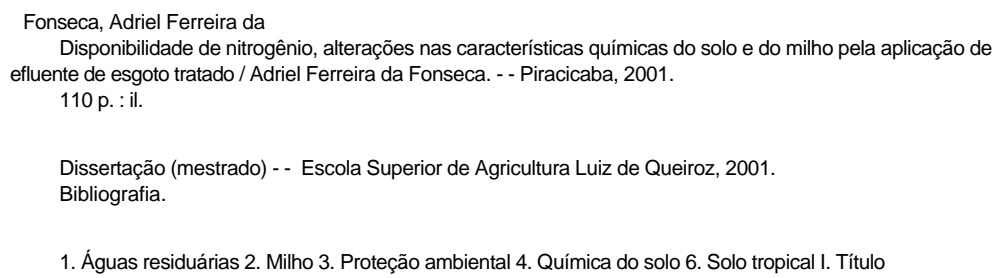

1. Águas residuárias 2. Milho 3. Proteção ambiental 4. Química do solo 6. Solo tropical I. Título

CDD 633.15

"Permitida a cópia total ou parcial deste documento, desde que citada a fonte - $\mathrm{O}$ autor" 
Aos meus pais

\section{Eliud e Rita}

\section{OFEREÇO}

Ao meu sogro e à minha sogra

João e Ivone

a minha homenagem

À minha querida esposa Fabiana

DEDICO 


\section{AGRADECIMENTOS}

O autor expressa seus agradecimentos às seguintes pessoas e instituições, sem o apoio das quais não teria sido possível a realização do presente trabalho:

Ao Prof. Dr. Adolpho José Melfi, pelo estímulo, confiança e orientação ao presente trabalho.

À Prof ${ }^{a}$. Célia Regina Montes (Departamento de Solos e Nutrição de Plantas USP/ESALQ), pelo apoio, sugestões e valiosas críticas em todas as etapas experimentais.

Ao Prof. Quirino Augusto de C. Carmello (Departamento de Solos e Nutrição de Plantas -USP/ESALQ) pelas sugestões e valioso auxílio na condução do experimento e análises laboratoriais.

À Coordenação do Programa de Pós-Graduação em Solos e Nutrição de Plantas da USP/ESALQ por possibilitar a realização do Mestrado, bem como do presente trabalho.

Aos funcionários Clotilde Maria Batochio, Paulo Sebastião e Sérgio Luis de Jesus e demais integrantes da USP/Nupegel, pela amizade e auxílio despendido durante esses dois últimos anos.

Aos demais funcionários e professores do Departamento de Solos e Nutrição de Plantas - USP/ESALQ, que contribuíram direta ou indiretamente para realização do presente trabalho.

Aos Professores, funcionários e ao amigo Solismar, do Laboratório de Biogeoquímica Ambiental (USP/CENA), por toda a atenção despendida.

Aos colegas da Pós-Graduação, bem como aos da USP/Nupegel: Liliane Ibrahim, Márcia T. S. Soares, Camila B. Jordão, Vania Rosolen. 
À Companhia de Saneamento Básico do Estado de São Paulo (Sabesp/Lins) pela atenção e auxílio na coleta de solo e efluente de esgoto tratado.

À Fundação de Amparo à Pesquisa do Estado de São Paulo (FAPESP) pelo apoio financeiro. 


\section{SUMÁRIO}

Página

LISTA DE FIGURAS.................................................................. ix

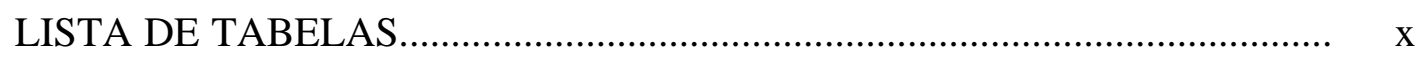

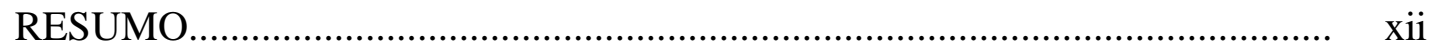

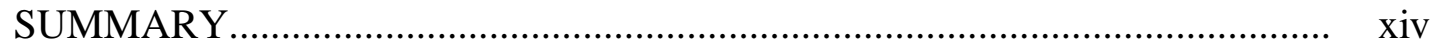

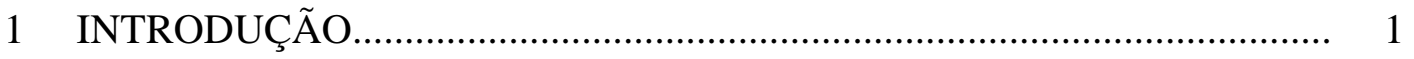

2 REVISÃO DE LITERATURA.......................................................... 4

2.1 Tratamento de esgoto e produção de efluentes......................................... 4

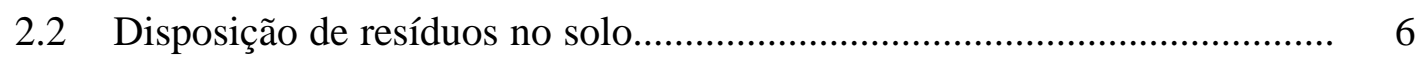

2.3 Vantagens da irrigação com efluente de esgoto tratado e a importância da reutilização da água.......................................................................... $\quad 10$

2.4 Característica do efluente de esgoto tratado........................................... 13

2.5 Impacto da disposição de efluente no sistema solo-planta-ambiente 15

2.5.1 Efeito nas características químicas e físicas do solo.............................. 15

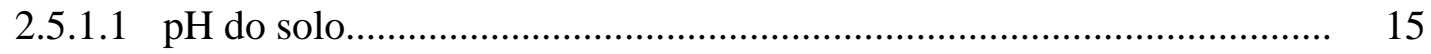

2.5.1.2 Carbono e nitrogênio..................................................................... 18

2.5.1.3 Fósforo e enxofre.......................................................................... 22

2.5.1.4 Cálcio, magnésio e potássio........................................................... 25

2.5.1.5 Micronutrientes e elementos tóxicos................................................ 26

2.5.1.6 Salinidade, sodicidade e condutividade hidráulica.............................. 28

2.5.2 Efluente de esgoto tratado como fertilizante e efeitos na nutrição das

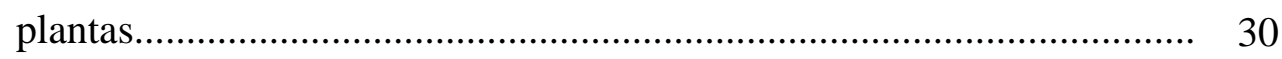

2.5.3 Efeito na produtividade das culturas................................................. 34

2.5.3.1 Grandes culturas......................................................................... 34 
2.5.3.2 Plantas olerícolas e frutíferas

2.5.3.3 Plantas forrageiras................................................................... 37

2.5.3.4 Florestamentos................................................................... 39

2.6 Sustentabilidade da irrigação de plantas com efluente de esgoto tratado.

2.7 Análise crítica da revisão bibliográfica.................................................. 44

3 MATERIAL E MÉTODOS.............................................................. 47

3.1 Caracterização do efluente de esgoto tratado......................................... 47

3.2 Experimento 1: Efeito da aplicação de efluente de esgoto tratado na disponibilidade de nitrogênio do solo....................................................... 49

3.2.1 Local do experimento, preparo e caracterização do substrato................ 49

3.2.2 Delineamento experimental e tratamentos......................................... 49

3.2.3 Características do efluente utilizado................................................. 50

3.2.4 Condução do experimento e análise química de terra............................ 50

3.2.5 Cálculo do nitrogênio mineral disponível e análises estatísticas............ 52

3.3 Experimento 2: Alterações nas características químicas do solo, nutrição e produção de matéria seca do milho pela aplicação de efluente de esgoto tratado.

3.3.1 Local do experimento, preparo do substrato e caracterização do efluente.

3.3.2 Delineamento experimental e tratamentos....................................... 55

3.3.3 Condução do experimento................................................................. 55

3.3.4 Medição indireta da clorofila........................................................... 58

3.3.5 Avaliação da quantidade de matéria seca........................................... 58

3.3.6 Acúmulo de nutrientes e elementos tóxicos....................................... 58

3.3.7 Análise da terra........................................................................... 59

3.3.8 Análises estatísticas.................................................................... 59

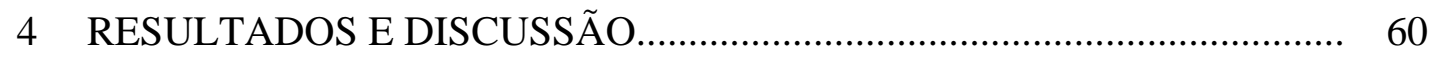

4.1 Efeito da aplicação de efluente de esgoto tratado na disponibilidade de nitrogênio no solo. 
4.1.1 Nitrogênio total, carbono orgânico total e pH........................................... 60

4.1.2 Nitrogênio mineral............................................................................. 65

4.2 Alterações nas características químicas do solo, nutrição e produção de matéria seca do milho pela aplicação de efluente de esgoto tratado............ 69

4.2.1 Apresentação dos resultados.................................................................. 69

4.2.1.1 Qualidade do efluente e aporte de nutrientes pela irrigação.................... 69

4.2.1.2 Efeitos no solo............................................................................... 70

4.2.1.3 Efeitos nas plantas....................................................................... 74

4.2.2 Discussão dos resultados..................................................................... 81

4.2.2.1 Considerações sobre o efluente utilizado no experimento........................ 81

4.2.2.2 Acidez ativa, potencial e trocável........................................................... 81

4.2.2.3 Carbono, fósforo e enxofre................................................................... 83

4.2.2.4 Nitrogênio e clorofila........................................................................... 85

4.2.2.5 Cálcio, magnésio, potássio e sódio.......................................................... 87

4.2.2.6 Condutividade elétrica........................................................................ 90

4.2.2.7 Capacidade de troca catiônica efetiva e potencial..................................... 91

4.2.2.8 Micronutrientes e elementos tóxicos...................................................... 92

4.2.2.9 Produção de matéria seca....................................................................... 94

5 CONCLUSÕES................................................................................ 97

REFERÊNCIAS BIBLIOGRÁFICAS............................................................... 99 


\section{LISTA DE FIGURAS}

Página

1 Lagoas de estabilização operadas pela Sabesp na Unidade de Negócios do Baixo Tietê e Grande, município de Lins (SP)....................................... 48

2 Valores das temperaturas máximas, mínimas e médias na casa-de-vegetação durante o decorrer do experimento.............................................................. 57

3 Efeitos da aplicação de efluente secundário de esgoto tratado no (A) $\mathrm{pH}$ e (B) nos teores de nitrogênio total (NT) e (C) carbono orgânico total (COT) das amostras de terra, no início (• - tempo 0 de incubação) e no final (• - 70 dias de incubação

4 Relações entre o aporte de nitrogênio total (NT) nas amostras de terra pela adição semanal de 100 (A), 150 (B) e $200 \mathrm{~mL}$ de efluente $\mathrm{kg}^{-1}$ de terra (C) e o teor de $\mathrm{N}$-mineral disponível $\left(\mathrm{N}-\mathrm{NH}_{4}{ }^{+}+\mathrm{N}-\mathrm{NO}_{3}{ }^{-}\right)$, sete dias após a última aplicação de efluente

5 Efeitos da aplicação do efluente secundário de esgoto tratado e/ou adubação nitrogenada nas plantas de milho, 58 dias após a emergência. 


\section{LISTA DE TABELAS}

Página

1 Características típicas do efluente secundário de esgoto tratado no mundo.....

2 Resultados de análises químicas da amostra de terra utilizada para instalação do experimento 1 .

3 Características químicas do efluente secundário de esgoto tratado oriundo da Estação de Tratamento de Esgoto de Lins, empregado no experimento 1........

4 Resultados de análises químicas e granulométricas da amostra de terra utilizada para instalação do experimento 2 ................................................... 54

5 Características químicas do efluente secundário de esgoto tratado oriundo da Estação Tratamento de Esgoto de Lins, empregado no experimento 2........... 56

6 Quantidades e fontes de nutrientes aplicados nas amostras de terra................ 57

7 Taxas de aplicação do efluente secundário de esgoto tratado e provável aporte de alguns dos seus constituintes (calculados a partir da Tabela 5) nas amostras de terra, durante o decorrer do período

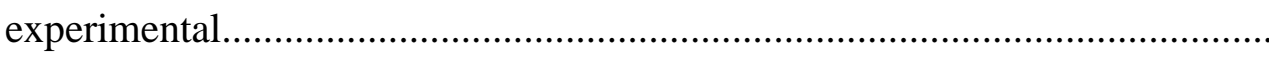

8 Coeficientes de correlação entre o teor de nitrogênio mineral $\left(\mathrm{N}_{-} \mathrm{NH}_{4}{ }^{+}+\mathrm{N}-\right.$ $\mathrm{NO}_{3}{ }^{-}$) nas amostras de terra pela adição semanal de 100, 150 e $200 \mathrm{~mL}$ de efluente $\mathrm{kg}^{-1}$ de terra e os teores de $\mathrm{N} \mathrm{NH}_{4}{ }^{+}$e $\mathrm{N}_{-} \mathrm{NO}_{3}{ }^{-}$, sete dias após a última aplicação de efluente.

9 Grau de restrição de uso do efluente secundário de esgoto tratado de Lins para irrigação por superfície.

10 Resultados de análise química da água consumida pela população de Lins/SP 
11 Provável aporte de matéria orgânica total, nutrientes e elementos tóxicos, adicionados às unidades experimentais (calculados a partir da Tabela 5) pela irrigação das plantas de milho com efluente secundário de esgoto tratado (ESET)

12 Efeitos de fontes d'água para irrigação (efluente e água deionizada) e adubação no $\mathrm{pH}$, condutividade elétrica $(\mathrm{CE})$ e nos teores de $\mathrm{H}+\mathrm{Al}, \mathrm{Al}, \mathrm{Na}$, carbono orgânico total (COT), nitrogênio total (NT) e demais macronutrientes no solo, após o corte das plantas de milho.

13 Efeitos de fontes d'água para irrigação (efluente e água deionizada) e adubação na capacidade de troca catiônica (CTC) e na CTC efetiva $\left(\mathrm{CTC}_{\mathrm{e}}\right)$, saturação por bases (V) e por alumínio (m), percentual de sódio trocável (PST) e nos teores de micronutrientes e elementos tóxicos das amostras de terra.

14 Efeitos de fontes d'água para irrigação (efluente e água deionizada) e adubação mineral na força iônica (I) da solução do solo, calculada a partir da condutividade elétrica ( $\log I=1,159+1,099 \log C E)$

15 Efeitos de fontes d'água para irrigação (efluente e água deionizada) e adubação no conteúdo de macronutrientes, pelas folhas, colmos e toda parte aérea das plantas de milho, 58 dias após a emergência.....

16 Efeitos de fontes d'água para irrigação (efluente e água deionizada) e adubação no conteúdo de $\mathrm{Na}$ e micronutrientes pelas folhas, colmos e toda parte aérea das plantas de milho, 58 dias após a emergência

17 Efeitos de fontes d'água para irrigação (efluente e água deionizada) e adubação na concentração de nitrogênio e clorofila, medidas na terceira folha completamente expandida e na produção de matéria seca pelas folhas, colmos e toda parte aérea das plantas de milho, 58 dias após a emergência.... 


\title{
DISPONIBILIDADE DE NITROGÊNIO, ALTERAÇÕES NAS CARACTERÍSTICAS QUÍMICAS DO SOLO E DO MLHO PELA APLICAÇÃO DE EFLUENTE DE ESGOTO TRATADO
}

\author{
Autor: ADRIEL FERREIRA DA FONSECA \\ Orientador: Prof. ADOLPHO JOSÉ MELFI
}

\section{RESUMO}

Os efluentes de esgoto tratado quando dispostos nos cursos d'água têm ocasionado sérios impactos ambientais pelo aporte de matéria orgânica e nutrientes, principalmente $\mathrm{N}$ e P. Por outro lado, diversos países têm feito a disposição dos efluentes tratados no solo, mediante a irrigação de plantas, com triplo propósito: tratamento complementar, fonte d'água e de nutrientes ao sistema solo-planta. Então, instalaram-se dois experimentos em condições controladas, na USP/ESALQ, em Piracicaba (SP), com amostras de terra de um Latossolo Vermelho distrófico e efluente secundário de esgoto tratado (ESET), ambos oriundos de Lins (SP). O objetivo principal do presente trabalho foi avaliar o potencial de uso e o impacto da utilização deste resíduo como fonte de $\mathrm{N}$ e água. No primeiro experimento, empregoutse o delineamento inteiramente casualizado, com quatro tratamentos, quatro repetições e onze períodos de incubação das amostras de terra (de 0 a 10 semanas). Foram aplicados semanalmente 0, 100, 150 e $200 \mathrm{~mL}$ de efluente (contendo $49 \mathrm{mg} \mathrm{L}^{-1}$ de $\mathrm{N}$-total, predominantemente na forma de $\mathrm{N}_{-} \mathrm{NH}_{4}^{+}$) por $\mathrm{kg}$ de solo. O efluente foi aplicado nas amostras de solo simulando-se uma irrigação por superfície. Sete dias após a última adição de efluente, as unidades experimentais foram sucessivamente desmontadas e determinaram-se os teores 
de N-mineral mediante extração com solução $\mathrm{KCl} 2 \mathrm{~mol} \mathrm{~L}^{-1}$ e leitura por espectrometria de absorção molecular. Os teores de $\mathrm{N}_{-} \mathrm{NO}_{3}{ }^{-}$, bem como de $\mathrm{N}$-mineral total aumentaram com o aumento da taxa de aplicação do ESET. Em média, 36\% do N-efluente não foi recuperado, tendo certamente, sido perdido por volatilização e/ou denitrificação. $\mathrm{O}$ segundo experimento, consistiu na adição de ESET nos vasos cultivados com de milho, em casa-de-vegetação. O delineamento experimental empregado foi o de blocos completos casualizados, com cinco repetições e cinco tratamentos a saber: (i) irrigação com água e adubação mineral completa, exceto $\mathrm{N}$; (ii) irrigação com água e adubação mineral completa; (iii) somente irrigação com efluente, sem nenhuma adição de fertilizante mineral; (iv) irrigação com efluente e adubação mineral completa, exceto N; (v) irrigação com efluente e adubação mineral completa. As plantas receberam efluente de acordo com a necessidade de irrigação, por 58 dias após a emergência. Decorrido este período, as plantas foram colhidas, avaliaram-se a quantidade de matéria seca, o conteúdo de nutrientes e de elementos tóxicos. Os mesmos elementos/nutrientes foram determinados nas amostras de solo e ainda, $\mathrm{pH}$ e CE. O efluente mostrourse eficiente em substituir totalmente a água de irrigação, porém parcialmente a fertilização nitrogenada e não nutriu adequadamente as plantas na ausência total de fertilizantes minerais. Por outro lado, o ESET de Lins mostrou-se pobre em metais pesados, constituindo-se em um fator positivo para sua utilização na agricultura. Também, as unidades experimentais irrigadas com ESET tiveram menor acidificação. Todavia, tanto o teor de $\mathrm{Na}$ nas amostras de terra quanto o conteúdo deste nutriente pelas plantas foram influenciados pelo ESET. Os altos teores de Na no efluente de Lins poderiam, pelo menos em parte, ser explicados pelo fato da água consumida no município de Lins ser originalmente rica em Na. 


\title{
NITROGEN AVAILABILITY, CHANGES IN THE OF SOIL AND CORN CHEMICAL CHARACTERISTICS BY APPLICATION OF TREATED SEWAGE EFFLUENT
}

\author{
Author: ADRIEL FERREIRA DA FONSECA \\ Adviser: Prof. Dr. ADOLPHO JOSÉ MELFI
}

\section{SUMMARY}

Normally, sewage effluents are treated in the sewage plants, and they are discharged into rivers. This practice has contributed to environmental impact because of the input of organic matter and nutrients, mainly $\mathrm{N}$ and $\mathrm{P}$. On the other hand, several countries have been using this wastewater for crop irrigation with three purposes: complementary treatment, water and nutrients sources to the soil-plant system. Two experiments were carried out at USP/ESALQ, under controlled conditions, in Piracicaba - SP (Brazil) with samples of Red Latosol and secondary-treated sewage effluent (STSE) from Lins (SP), with the aim at evaluating the potential and the impact of this wastewater as nitrogen and water sources. In the first experiment, it was used a randomized complete design with four treatments and four replications, and eleven periods of soil samples incubation ( 0 to 10 weeks). The rates of effluent application were $0,100,150$ and $200 \mathrm{~mL}$ of STSE (49 $\mathrm{mg} \mathrm{L}^{-1}$ of $\mathrm{N}$-total, predominantly $\mathrm{N}^{-\mathrm{NH}_{4}}{ }^{+}$) per week per $\mathrm{kg}$ of soil. It was similar to a surface irrigation. Seven days after the last effluent application, the samples were collected to analyze the total mineral nitrogen though extraction with $\mathrm{KCl} 2 \mathrm{~mol} \mathrm{~L}^{-1}$ and it was measured by molecular absorption spectrometry. It was observed that the mineral $\mathrm{N}$ concentration increased with 
application rate of STSE, mainly $\mathrm{N}^{-\mathrm{NO}_{3}}{ }^{-}$. About $36 \%$ of $\mathrm{N}$-effluent probably were lost through denitrification or volatilization. The second experiment was carried out to observe corn plants irrigated with STSE in pots, in the greenhouse. The experimental design was randomized blocks with five replications, and five treatments. The treatments were: (i) irrigation with water plus mineral fertilization, but $\mathrm{N}$; (ii) irrigation with water plus the whole fertilization; (iii) irrigation with STSE alone; (iv) irrigation with STSE plus mineral fertilization, but N; (v) irrigation with STSE plus the whole fertilization. The experimental period was 58 days after corn plant emergency. Then, the plants were harvested, and the nutrient concentrations as well as toxic elements, in soil sample and plants were analyzed. It was determined the $\mathrm{pH}$ and EC in each soil sample. Lins' effluent was poor in heavy metals and these elements were not problematic in the soilplant system. This effluent substituted completely the irrigation water except for the mineral fertilizer, although it affected the uptake of nutrients. It was observed smaller soil acidification of the treatments that received effluent. There were not differences between the whole fertilization plus irrigation with water or STSE, due to the same production of dry matter by corn plants. The major problem of Lins' STSE was the high $\mathrm{Na}$ concentration, and the content this of element was greatly increased by plants and the $\mathrm{Na}$ accumulated in the soil samples. This high concentration of $\mathrm{Na}$ in the Lins' effluent could be, in part, due to the fact that the water consumed by the Lins' population is naturally rich in this element. 


\section{INTRODUÇÃO}

O tratamento de esgoto através de sistemas de lagoas de estabilização tem sido amplamente utilizado no mundo, inclusive no interior do Estado de São Paulo. Somente na Unidade de Negócios do Baixo Tietê e Grande, operada pela Sabesp (Companhia de Saneamento Básico do Estado de São Paulo), existem 195 sistemas de lagoas, cuja produção de efluentes é da ordem de $1,5 \mathrm{~m}^{3} \mathrm{~s}^{-1}$.

O efluente de esgoto tratado (EET) caracteriza-se por ser um material líquido, que possui algumas características peculiares diferindo-o da água convencional. As principais diferenças em relação à água consistem na presença de matéria orgânica expressa pela demanda química de oxigênio (DQO - quantidade de oxigênio necessária para oxidar a matéria orgânica) e demanda bioquímica de oxigênio (DBO - quantidade de oxigênio requerida para degradação microbiana de compostos orgânicos nas águas residuárias a $20^{\circ} \mathrm{C}$ ), macro e micronutrientes, metais pesados essenciais e não essenciais às plantas, orgânicos traços e patógenos.

O modo mais fácil, porém não sustentável, de se livrar desse tipo de material consiste na sua disposição direta nos cursos d'água. Entretanto, esta prática tem sido muito criticada pois tem ocasionado sérios impactos ambientais como a eutroficação de águas. Com o aumento da consciência ecológica da população e de uma série de restrições legais, a disposição de efluentes sem o tratamento terciário nos cursos d'água vem sendo proibida em diversos países.

Apesar do efluente representar um problema ambiental, o mesmo apresenta características desejáveis agronomicamente. Tais vantagens referem-se ao seu potencial como fertilizante, pois é rico em nutrientes, principalmente nitrogênio, fósforo e potássio e sobretudo, apresenta potencialidade de uso como fonte d'água às plantas. 
Além disso, a competição por recursos hídricos limitados, aumentada em função da crescente demanda urbana e industrial, tem favorecido procedimentos visando sua maior reutilização na agricultura. Assim, a irrigação de plantas com efluente de esgoto tratado tem sido considerada como um método alternativo de tratamento de efluentes no solo, principalmente em regiões secas. Países como Austrália, Israel e EUA, vêm utilizando com sucesso a fertirrigação com EET.

É, portanto, interessante realizar a disposição de efluentes no solo ao invés de fazê-la em cursos d'água e com isso, aproveitar a capacidade filtrante da matriz do solo para reter nutrientes, poluentes e patógenos. Esta prática, caracteriza-se por ser uma tecnologia simples e de baixo custo para o tratamento terciário de esgoto.

A disposição de efluentes no solo consiste no fornecimento de água e nutrientes ao sistema solo-planta, os quais poderão ser utilizados pelas plantas para produção de matéria seca. Desde que bem planejada e monitorada, a aplicação de efluentes no solo tem apresentado sustentabilidade econômica e ambiental em diversos locais no exterior.

Desse modo, a utilização sustentável de efluentes na irrigação implicará em reciclar a matéria orgânica e nutrientes dos efluentes de lagoa, visando: (i) a economia de fertilizantes; (ii) a liberação de outras fontes de água para consumo humano; (iii) a resolução de problemas advindos das descargas desses efluentes nas águas de superfície ou subterrânea; (iv) a melhoria das condições químicas, físicas e biológicas do solo devido a adição de nutrientes e de matéria orgânica.

Apesar dos efluentes possuírem potencialidade de uso na agricultura, há falta de tradição na reciclagem dos mesmos, principalmente no Brasil. Consequentemente, existem poucas informações concernentes aos efeitos de sua disposição em solos com carga variável (solos tropicais). Desse modo, torna-se evidente a importância de estudar os efeitos decorrentes da disposição de EET em solo tropical, no ambiente e nas plantas.

Os objetivos do presente trabalho foram: (i) levantar informações na literatura internacional concernentes ao efeito da disposição de EET no sistema solo-plantaefluente-ambiente; (ii) caracterizar o efluente secundário de esgoto tratado (ESET) produzido na Estação de Tratamento de Esgoto (ETE) de Lins/SP; (iii) determinar a 
disponibilidade de nitrogênio no solo que recebeu ESET; (iv) comparar o uso de ESET $v s$. adubação mineral, no que diz respeito ao suprimento de nitrogênio à cultura do milho, em condições de casa-de-vegetação; (v) avaliar o teor de clorofila, o estado nutricional e a produção de matéria seca das plantas de milho irrigadas com ESET; (vi) avaliar os efeitos da disposição do ESET de Lins/SP nas propriedades químicas do solo. 


\section{REVISÃO DE LITERATURA}

\subsection{Tratamento de esgoto e produção de efluentes}

Na América Latina e no Caribe apenas 49\% da população são beneficiadas com redes de coleta e afastamento de esgotos e aproximadamente três por cento dos esgoto produzidos são tratados (Léon Suematsu \& Moscoso Cavallini, 1999). Dentre os vários métodos empregados no tratamento dos esgotos gerados, o sistema de lagoas de estabilização tem sido amplamente utilizado no mundo, notadamente nas pequenas cidades do interior do Estado de São Paulo, como é o caso de Lins. Esse tipo de tratamento de esgoto tem sido sustentável em comunidades rurais e cidades de pequeno a médio porte, situadas em locais de clima quente e que não há limitação geográfica de terreno, devido a grande área exigida (Feigin et al., 1991),

As hgoas de estabilização correspondem a uma opção tecnológica de baixo custo para se alcançar plenamente o objetivo de "ausência de patógenos" na água de esgoto. Nenhum sistema convencional de tratamento de esgoto pode competir com a eficiência de remoção de microrganismos que se obtém nas lagoas de estabilização, exceto naqueles em que são adicionados algum produto químico ao processo de desinfecção do efluente, o que encarece e torna mais complexa a sua operação e manutenção (Léon Suematsu \& Moscoso Cavallini, 1999).

Os sistemas de lagoas de estabilização de águas residuárias são, normalmente, divididos em três diferentes etapas, dependendo da carga orgânica pelo aporte dos resíduos e dos objetivos de qualidade do efluente (Pescod, 1992).

A primeira fase ocorre nas lagoas anaeróbias (tratamento primário) onde ocorre, principalmente, diminuição na $\mathrm{DBO}$ e remoção grosseira de sólidos orgânicos e inorgânicos, gorduras e óleos (Feigin et al., 1991). Em certos casos, essas lagoas tornam- 
se cobertas por resíduos grosseiros, os quais têm efeitos benéficos, porém não essenciais, podendo aumentar a eficiência do tratamento de esgoto (Pescod, 1992). As reações anaeróbias são mais lentas que as aeróbias e podem originar odores desagradáveis. As condições anaeróbias são geradas quando o consumo de oxigênio dissolvido na massa de água é superior à quantidade de oxigênio incorporada à mesma, por meio de fotossíntese, pelas algas, ou pela aeração mecânica da superfície. A aplicação de uma carga orgânica superficial muito alta faz com que as algas e o oxigênio dissolvido desapareçam, fazendo com que a lagoa se torne de cor cinzento-escuro. Desse modo, a degradação da matéria orgânica ocorre de forma mais lenta e são gerados odores desagradáveis pela formação de ácido sulfídrico. Na etapa final do processo anaeróbio, ocorrem as fases acetogênica e metanogênica, que formam metano, hidrogênio e dióxido de carbono (Léon Suematsu \& Moscoso Cavallini, 1999).

A segunda etapa (tratamento secundário), que ocorre nas chamadas lagoas facultativas, é a mais importante no tratamento de esgoto (Feigin et al., 1991). As lagoas facultativas são extensas e relativamente rasas. Nelas ocorrem os processos de oxidação, aeração, biológicos aeróbio (próximo da superfície) e anaeróbio (em profundidade). Neste estádio do tratamento de esgoto, a matéria orgânica presente numa massa de água contendo oxigênio dissolvido é decomposta ou oxidada pelos microrganismos (Pescod, 1992). Neste processo participam bactérias aeróbias ou facultativas e se originam compostos inorgânicos que servem de nutrientes às algas. Por sua vez, estas produzem mais oxigênio e permitem a atividade das bactérias aeróbias. Existe, pois, uma simbiose entre bactérias e algas, que facilita a estabilização aeróbia da matéria orgânica. Nas lagoas de estabilização as águas residuárias não se depuram como nas estações de tratamento convencional, porém se estabilizam, pois as algas são matéria orgânica viva que não exerce DBO. As algas têm importante papel nas lagoas de estabilização facultativas pelo fato de produzirem $\mathrm{O}_{2}$, o qual é vital para as bactérias aeróbias que participam da oxidação da matéria orgânica (Léon Suematsu \& Moscoso Cavallini, 1999). Durante o percurso do fluxo das águas residuárias no sistema de lagoas de estabilização, até mais de $60 \%$ do total de N inorgânico pode ser perdido (Lund, 1999). 
A terceira fase ocorre nas chamadas lagoas de maturação, cuja função principal é a remoção de patógenos visando elevar a qualidade do efluente. Esta fase, também denominada de tratamento terciário, não é obrigatória (Pescod, 1992). O tratamento terciário envolve, normalmente, processos de cloração, filtragem, coagulação e remoção de sólidos suspensos, nutrientes, fatores de eutroficação e turbidez e ainda, a eliminação de patógenos resistentes (Feigin et al., 1991).

Os produtos finais do tratamento de esgoto, mediante emprego de lagoas de estabilização são o lodo de esgoto e o efluente. O primeiro, também denominado de biossólido, caracteriza-se por ser um produto semi-sólido, constituído principalmente por flocos biológicos que se sedimentam no fundo das lagoas de estabilização. $O$ segundo, também conhecido por água residuária, é a água utilizada ou gasta por uma comunidade ou indústria, que apresenta sólidos inorgânicos e matéria orgânica em suspensão ou dissolvida (Pescod, 1992). Denomina-se efluente primário, secundário e terciário a água residuária oriunda dos tratamentos primário, secundário e terciário, respectivamente.

O efluente produzido nestes sistemas de lagoas tem sido disposto, na maioria das vezes, nos cursos d'água de superfície. Assim, cerca de $40 \mathrm{Mm}^{3}$ de água residuária são diariamente descarregadas nos cursos d'água na América Latina e no Caribe (Léon Suematsu \& Moscoso Cavallini, 1999). Na região de Lins (SP), a situação não é muito diferente, ou seja, na Unidade de Negócios do Baixo Tietê e Grande, há 195 sistemas de lagoas de estabilização operadas pela Sabesp, nas quais são produzidos anualmente cerca de $73.000 \mathrm{~m}^{3}$ de lodo de esgoto e 46,9 $\mathrm{Mm}^{3}$ de efluente ${ }^{1}$, a disposição desse montante de efluente tratado tem sido, normalmente, realizada nos cursos d'água.

\subsection{Disposição de resíduos no solo}

No passado, o caminho mais fácil para a disposição de resíduos, bem como das águas residuárias, eram os rios, lagos, mares ou recobrindo o solo sem as devidas considerações sobre as conseqüências de risco de saúde e dano ambiental. Porém, esses

\footnotetext{
${ }^{1}$ Dados fornecidos pela Sabesp (Companhia de Saneamento Básico do Estado de São Paulo), Unidade de Negócios do Baixo Tietê e Grande, município de Lins (2001)
} 
métodos, altamente dependentes da renovação por processos naturais, tornaram-se inadequados mediante o aumento populacional e industrial, associado à limitada capacidade assimilativa do ambiente (Feigin et al., 1991) e à escassez de recursos hídricos (Bouwer, 2000).

Assim, a disposição de resíduos ricos em nutrientes, principalmente em $\mathrm{N}$ e $\mathrm{P}$, nos rios, oceanos e outros corpos d'água, tem levado à eutroficação de águas e contribuído para floração de algas tóxicas azuis-verdes (Dorich et al., 1984). Porém, nos anos recentes, tem havido incremento da pressão populacional para que essa prática fosse evitada (Bond, 1998). Isso tem ocorrido devido ao aumento da consciência ecológica das pessoas, da necessidade de preservar a qualidade das águas de superfície e de subsuperfície e de várias restrições legais concernentes a disposição de poluentes nos cursos d'água (Bouwer \& Chaney, 1974).

Em certos países, razões culturais favorecem a aplicação de resíduos ao solo ao invés de descarregá-los nos corpos d'água (Cameron et al., 1997). Em outros, como o Brasil, há falta de tradição na reciclagem dos resíduos gerados, particularmente do efluente de esgoto. Todavia, nos anos recentes, a aplicação de resíduos orgânicos na agricultura tem recebido atenção considerável pelo aumento crescente do requerimento de energia para produção de fertilizantes minerais e por causa dos custos e problemas ambientais associados com métodos alternativos de disposição de resíduos (Chae \& Tabatabai, 1986). Isso tem levado a um aumento expressivo do número de publicações relacionadas à utilização de resíduos orgânicos no solo. No entanto, geralmente não tem sido abordado os benefícios econômicos, energéticos e ambiental dos mesmos (Sims, 1996).

Embora a aplicação de resíduos ao solo está se tornando mais difundida como regulamento das autoridades para proteger a qualidade d'água, ainda não está bem claro se o solo é de fato, o local mais apropriado para receber todos os resíduos gerados pela ação antrópica (Cameron et al., 1997).

Os resíduos líquidos mais comuns aplicados ao solo incluem água de esgoto convencionalmente tratada, lodo de esgoto líquido (com mais de 95\% de água), dejetos 
líquidos de animais, efluentes do processamento de frutas, vegetais, produtos de origem animal, leiterias e indústrias de produtos fibrosos (Bouwer \& Chaney, 1974).

A aplicação de resíduos orgânicos e água residuária no solo tem sido comum desde muitos anos como um processo de tratamento e meio de disposição (Feigin et al., 1991). Nos tratamentos convencionais, a energia contida nos esgotos é dissipada mediante a mineralização da matéria orgânica e lançando-se os nutrientes nos corpos receptores. Porém, através da disposição de esgotos no solo, a energia é canalizada e utilizada para produção de alimentos, recarga de aquíferos, irrigação e outros fins (Paganini, 1997).

Quando os efluentes são aplicados, de forma controlada, na superfície do solo, os mesmos podem adquirir um maior grau de tratamento através dos processos físicos, químicos e biológicos da matriz solo-planta-água. O solo, sendo um sistema vivo e dinâmico, caracterizado por ter uma grande superfície ativa e resultante de processos físicos, químicos e biológicos, reage fortemente com os constituintes do efluente. Os compostos orgânicos decompõe-se em $\mathrm{CO}_{2}, \mathrm{H}_{2} \mathrm{O}$ e compostos inorgânicos. Os constituintes inorgânicos podem ser trocáveis, adsorvidos ou precipitados, seguindo reações químicas que os transformem em compostos de baixa solubilidade, ou eles podem ser absorvidos pelas plantas e consequentemente, serem parcialmente removidos da solução de fluxo. Assim, o solo e as plantas atuam como verdadeiros "filtros vivos", absorvendo e retendo poluentes e organismos patogênicos presentes nos resíduos e efluentes (Feigin et al., 1991).

A disposição no solo é considerado o método mais favorável para o controle do aumento de volume de águas residuárias das atividades de vida urbana e industrial (Feigin et al., 1978). Ao mesmo tempo, a aplicação ao solo e a reutilização de águas residuárias tratadas tem sido uma solução efetiva do custo potencial para o problema de disposição dos efluentes no ambiente (Darwish et al., 1999). Na verdade, a aplicação dos efluentes tratados no solo completa uma seqüência de tratamentos para reduzir a concentração de microrganismos e de vários compostos orgânicos e inorgânicos a teores aceitáveis para a renovação da água (Feigin et al., 1991). 
A eficiência da disposição de efluentes e sua reutilização, depende de fatores combinados das propriedades do solo e tecnologia de irrigação (Oron et al., 1999). A capacidade de filtração do solo depende do tamanho e distribuição das partículas, teor de umidade, matéria orgânica e características de adsorção. A efetividade do processo de filtração depende também das características do sistema radicular das plantas e do regime de irrigação.

Apesar dos métodos de tratamento de efluentes no solo serem amplamente empregados no mundo, tanto em regiões áridas como regiões úmidas (Bouwer \& Chaney, 1974), eles estão sujeitos a críticas. Tais críticas, segundo Feigin et al. (1991), são baseadas nos seguintes fatores:

a) Risco de saúde pública, como transmissão de vírus e bactérias patogênicas para o homem e animais, contaminação do lençol freático por produtos químico perigosos e propagação de insetos vetores de doenças;

b) Efeito maléfico nas propriedades físicas e químicas do solo ao longo do tempo;

c) Escassez de disponibilidade de terra;

d) Aceite público de produtos obtidos de culturas que cresceram em solos irrigados com EET.

e) Viabilidade econômica

Entretanto, desde que bem fundamentado e manejado o projeto de disposição de efluentes ao solo, bem como o entendimento das características do sistema soloplanta-efluente-ambiente, as críticas e os desafios seguramente serão superados. Daí a importância do papel da Ciência do Solo no tocante à disposição de resíduos ao solo (Cameron et al., 1997), principalmente em relação à irrigação com efluente de esgoto tratado (Bond, 1998). Conclui-se então que o solo é um elemento depurador, efetivo em filtrar (Bouwer \& Chaney, 1974) e o sistema solo-planta atua como um reator renovável, no qual os esgotos passariam a atuar como fonte de energia e não como um grande problema ambiental (Paganini, 1997). 


\subsection{Vantagens da irrigação com efluente de esgoto tratado e a importância da reutilização da água}

Dentre os principais sistemas de disposição de águas residuárias no solo (irrigação, infiltração/percolação e escoamento à superfície), a irrigação de culturas tem sido o método mais acessível (Feigin et al., 1991) e eficiente (Darwish et al., 1999), particularmente, nos países em desenvolvimento onde não há uma política para o custo de tratamento das águas residuárias (Friedel et al., 2000).

Em determinadas regiões do México e da costa desértica do Peru, o desequilíbrio dos recursos hídricos e o crescimento explosivo das grandes cidades obrigaram a priorização do uso das águas superficiais para o abastecimento público e a geração de energia elétrica. Consequentemente, as atividades agrícolas desenvolvidas na periferia das cidades foram seriamente afetadas e assim, o uso das águas residuárias tornaram-se a única alternativa para sobrevivência. Isto, se reflete na existência de mais de 400.000 ha irrigados com esgoto, de forma direta, sendo na sua maioria sem tratamento prévio (Léon Suematsu \& Moscoso Cavallini, 1999).

O primeiro relato de irrigação com efluente de esgoto foi em 1897, na Fazenda Werribee, próximo a Melbourne, Austrália (Feigin et al., 1991). Na Nova Zelândia, o projeto pioneiro de irrigação com efluente iniciourse em 1958, na cidade de Templeton, com plantas forrageiras (Quin, 1978). Na China, o uso de esgoto na agricultura desenvolveu-se rapidamente a partir de 1958 e com isso, mais de um milhão de hectares vem sendo irrigados com EET (Pescod, 1992). Na Florida (EUA), a aplicação de água residuária municipal ao solo iniciou-se na cidade de Tallahasse, em 1966 (Allhands \& Overman, 1995). No Arizona (EUA), desde o final dos anos 1950, cereais e pastagens já recebiam, com sucesso, a irrigação com efluente de esgoto tratado (Day \& Tucker, 1959; Day et al., 1963). No México, há relatos de locais com mais de 80 anos irrigados com efluente de esgoto, aparentemente sem maiores problemas (Friedel et al., 2000). Em Israel, esta prática vem sendo corriqueira há mais de 50 anos. No início da década de 1990, cerca de $67 \%$ do total de EET gerado era utilizado na irrigação de pastagens e culturas agrícolas, principalmente no algodão ou na recarga de aqüíferos (Feigin et al., 1991). 
A reutilização dos efluentes tratados e/ou parcialmente tratados na irrigação de culturas agrícolas e/ou florestas, ao invés de descarregá-los nos cursos d'água, tem sido uma alternativa popular e atrativa (Bond, 1998) e tem tido uma rápida expansão nos anos recentes (Balks et al., 1998), por várias razões: (i) nos locais onde culturas necessitam ser irrigadas e os recursos hídricos são escassos, como é o caso das regiões áridas e semi-áridas, os efluente têm sido uma fonte suplementar d'água para sustentabilidade da agricultura irrigada (Bouwer \& Idelovitch, 1987; Al-Jaloud et al., 1995); (ii) a agricultura irrigada requer grandes quantidades de água que são utilizadas somente uma vez, visto que a irrigação basicamente é um uso consumível e consequentemente, o requerimento d'água para irrigação representa a maior parte do total de água demandada, principalmente nas regiões secas (Bouwer \& Idelovitch, 1987); (iii) o uso de EET na agricultura pode ser proveitoso não somente como fonte d'água, mas também, dentro de certas limitações, de outros recursos adicionais encontrados nas águas residuárias (Bouwer \& Idelovitch, 1987); (iv) as águas residuárias não somente mantém as águas de superfície, mas também, a sua disposição no solo implica em reciclagem, onde "poluentes" passam a ser nutrientes para o crescimento das plantas (Bouwer \& Chaney, 1974; Vazquez-Montiel et al., 1996); (v) a irrigação é relativamente flexível com despeito ao requerimento da qualidade d'água. Algumas culturas podem ser irrigadas com água de baixa qualidade sem maiores riscos e alguns problemas de qualidade d'água podem ser superados por práticas agronômicas sustentáveis (Bouwer \& Idelovitch, 1987).

É evidente a potencialidade do uso de efluentes como fonte d'água. Porém, o seu valor como fertilizante deveria ser mais detalhado. Assim, visando demonstrar a valorização econômica do efluente como adubo, Pescod (1992) apresentou um exemplo hipotético:

a) Uma cidade ou uma região, cuja população é de 500.000 habitantes e cujo consumo d'água per capita de $200 \mathrm{~L} \mathrm{dia}^{-1}$, a produção diária total de efluente seria $85.000 \mathrm{~m}^{3}$ (considerando que $85 \%$ do esgoto fosse canalizado para a ETE municipal). Assim, a produção anual de efluentes seria da ordem de $30 \mathrm{Mm}^{3}$. 
b) Aplicando-se uma lâmina de $500 \mathrm{~mm}^{\mathrm{ano}}{ }^{-1}$ de efluente, via irrigação, o montante de efluente gerado seria suficiente para irrigar 6.000 ha de lavoura.

c) Admitindo-se que o efluente tenha 50,10 e $30 \mathrm{mg} \mathrm{L}^{-1}$ de $\mathrm{N}$, P e K, respectivamente, a irrigação numa taxa de $500 \mathrm{~mm}$ ano $^{-1}$ adicionaria ao solo o equivalente a uma adubação com 0,55; 0,64 e 0,30 t ha ${ }^{-1}$ de uréia (45\% de $\mathrm{N}$ ), superfosfato simples $\left(18 \%\right.$ de $\left.\mathrm{P}_{2} \mathrm{O}_{5}\right)$ e cloreto de potássio $\left(60 \%\right.$ de $\left.\mathrm{K}_{2} \mathrm{O}\right)$, respectivamente.

Sem dúvida alguma, há vantagens na utilização dos efluentes das lagoas de estabilização na irrigação de culturas, apesar de não ser uma prática isenta de riscos. Medidas de proteção da saúde, que podem ser aplicadas na agricultura mediante o uso de EET, incluem não apenas um segmento isolado, mas a integração das medidas de controle, tais como: restrições de cultivo, tratamento dos efluentes, controle da aplicação de efluentes, exposição humana e higiene (Pescod, 1992).

O manejo adequado de solos irrigados com EET pode resultar em melhores produtividades, utilizando-se menos fertilizantes, com menor probabilidade de efeitos maléficos na qualidade da produção das plantas e na poluição de águas subterrâneas. Porém, o uso correto de efluente requer estudos individuais de várias culturas, levandose em consideração as condições específicas de clima e solo (Bond, 1998), inclusive estudos de longa duração (Feigin et al., 1978).

Muitos países já tem incluído a reutilização da água no planejamento de recursos hídricos, visto que os efluentes devem ser integrados nos recursos d'água global (Tanji, 1997; Bouwer, 2000). Em alguns casos, como Jordânia e Arábia Saudita, tem havido uma política nacional para reutilização de todos os efluentes (Pescod, 1992).

Certos fatores, como por exemplo, o crescimento populacional e padrões de vida mais elevados, têm levado ao aumento na demanda de água potável doméstica e industrial e consequentemente, incremento no fluxo de água de esgoto. Para atender o aumento da população, mais e mais água para irrigação de plantas tornar-se-á necessária. Os tratamentos requeridos para a disposição sustentável de efluentes nos corpos d'água de superfície têm sido grandemente dificultados, caros e inviáveis economicamente. Desse modo, todos esses fatores associados têm contribuído para a importância da reutilização da água (Bouwer, 2000). 


\subsection{Características do efluente de esgoto tratado}

As águas residuárias podem ser classificadas como doméstica, industrial e agrícola, em função da sua origem. A quantidade de efluente doméstico produzido é dependente do padrão de vida das pessoas, das condiçõos climáticas e da estação do ano e a suas características químicas são influenciadas pela fonte de água, sistema de esgoto, tipo de ETE (concepção do tratamento) e natureza de descarga industrial dentro do sistema municipal de esgoto (Feigin et al., 1991).

Embora o conteúdo de nutrientes presentes nos resíduos (inclusive águas residuárias) os deixem atrativos para serem utilizados como fertilizantes, aplicações ao solo de certos resíduos industriais e de esgoto têm sido constrangidas pela presença de metais pesados, certos compostos químicos orgânicos de alto risco, sais e valores extremos de pH (Cameron et al., 1997). Assim, é de fundamental importância separar esgoto doméstico de esgoto industrial, uma vez que os metais pesados e orgânicos não são, em geral, problemas nos efluentes domésticos (Feigin et al., 1991).

O uso do EET como fonte de água para irrigação pode, resumidamente, diferir da água convencional, segundo Bouwer \& Chaney (1974) e Feigin et al. (1991), em cinco aspectos básicos:

- Apresemtam uma variedade de compostos orgânicos naturais e sintéticos, geralmente não identificados individualmente. Normalmente são materiais orgânicos biodegradáveis, expressos em índices DBO e DQO. Os compostos orgânicos mais comuns existentes nos efluentes são: éter extraível, proteínas, carboidratos, taninos,

ligninas, diferentes ácidos orgânicos (fúlvicos, húmicos e hematomelânicos), aminoácidos e surfactantes. O efluente também pode conter traços de substâncias tóxicas como pesticidas. No entanto, as informações disponíveis não indicam ocorrência de problemas de saúde relatado pela presença de certos compostos orgânicos na água municipal reciclada.

- O uso municipal causa invariavelmente aumento na concentração de sais inorgânicos solúveis na água. A princípio, os íons são $\mathrm{Na}^{+}, \mathrm{CI}$ e $\mathrm{HCO}_{3}{ }^{-}$. Esses íons geram um aumento no conteúdo total de sais (salinidade) e na sodicidade da água. Os $\mathrm{HCO}_{3}{ }^{-} \mathrm{e} \mathrm{CO}_{3}{ }^{2-}$ podem aumentar o risco de sodicidade da água por ocasionar precipitação 
do carbonato de cálcio. Em pH menor que 8,4 predomina $\mathrm{HCO}_{3}{ }^{-}$e em $\mathrm{pH}$ maior que 8,4 predomina $\mathrm{CO}_{3}{ }^{2-}$. A concentração de $\mathrm{HCO}_{3}{ }^{-}$no EET tem sido muito maior que no suprimento de água original (em Israel, por exemplo, é duas vezes maior). Diferentemente de compostos orgânicos, os sais inorgânicos não são facilmente removidos durante os processos convencionais de tratamento e reciclagem, exceto para alguns carbonatos precipitados.

- Os efluentes contém diferentes teores de macronutrientes, especialmente $\mathrm{N}$

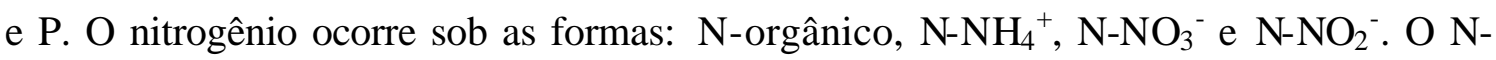
$\mathrm{NO}_{2}^{-}$raramente apresenta concentrações superiores a $1,0 \mathrm{mg} \mathrm{L}^{-1}$ devido à fácil oxidação para $\mathrm{N}_{-} \mathrm{NO}_{3}{ }^{-}$na presença de $\mathrm{O}_{2}$. $\mathrm{O} \mathrm{N}^{-} \mathrm{NO}_{3}{ }^{-}$varia de $0-10 \mathrm{mg} \mathrm{L}^{-1}$. No entanto, a maior parte do $\mathrm{N}$ nos efluentes municipais encontra-se na forma reduzida, principalmente $\mathrm{N}$ $\mathrm{NH}_{4}{ }^{+}$. Os efluentes contém várias formas de P: P-orgânico, fosfatos condensados (piro, meta e polifosfatos) e ortofosfato. O P-orgânico é resultante de processos biológicos e os fosfatos condensados são adicionados pela disposição de produtos químicos de lavanderias (detergentes) na água de esgoto.

- Elementos essenciais ou não às plantas podem estar presentes nos efluentes, principalmente nas águas residuárias industriais. Os teores de $\mathrm{As}, \mathrm{B}, \mathrm{Ba}, \mathrm{Cd}$, $\mathrm{Co}, \mathrm{Cr}, \mathrm{Cu}, \mathrm{F}, \mathrm{Hg}, \mathrm{Mn}, \mathrm{Mo}, \mathrm{Ni}, \mathrm{Pb}, \mathrm{Se}, \mathrm{V}$ e $\mathrm{Zn}$ nos efluentes de esgoto (inclusive efluente secundário) são determinados pelas propriedades químicas do esgoto bruto, da origem dos efluentes e do método de tratamento utilizado. Esses elementos são universalmente encontrados na água, mas em concentrações desprezíveis. No tratamento secundário do esgoto, mediante a decantação dos sólidos suspensos, esses elementos, principalmente os metais, podem ter suas concentrações reduzidas em até 70-90\%, pelo fato serem fortemente adsorvidos e precipitados juntamente com sólidos orgânicos e inorgânicos. Como resultado, estabilizam-se durante o tratamento nas lagoas, sedimentando-se junto ao lodo de esgoto. No entanto, certos metais pesados podem ocorrer nas águas residuárias como quelatos solúveis de baixo peso molecular.

- Microrganismos patogênicos (bactérias e vírus) estão presentes nas águas residuárias, apesar de suas concentrações nos efluentes serem grandemente reduzidas durante o processo normal de tratamento. Protozoários, como Endamoeba histolytica, 
parasitos e helmintos também podem estar presentes nos efluentes de esgoto. As bactérias patogênicas comumente encontradas nas águas residuárias são Salmonella, Shigella, Mycobacterium e Vibrio comma. Quanto às viroses, geralmente, incluem enterovírus e adenovírus. Desde que os teores de sólidos suspensos não sejam muito altos, a cloração tem sido eficiente no controle de patógenos e ainda, esta técnica tem sido amplamente utilizada na agricultura irrigada com efluente de esgoto tratado (Ayers \& Westcot, 1985; Bouwer \& Idelovitch, 1987; Pescod, 1992).

Então, é de fundamental importância conhecer as características químicas do efluente pelo fato dos processo que controlam a dinâmica dos resíduos no solo, como taxa de liberação e lixiviação, serem pobremente compreendidos (Cameron et al., 1997). Assim, mediante as extensas revisões de literatura realizadas por Bouwer \& Chaney (1974) e Feigin et al. (1991), foi possível obter os valores médios mundiais dos principais constituintes do ESET (Tabela 1).

Todavia, a qualidade microbiológica (Bouwer \& Chaney, 1974; Feigin et al. 1991) associada à tecnologia adequada de aplicação (Oron et al., 1999), à salinidade (Mujeriego et al., 1996) e aos teores de $\mathrm{N}^{-} \mathrm{NO}_{3}{ }^{-}$, metais pesados e orgânicos traços (Tanji, 1997), são os parâmetros essenciais de qualidade dos efluentes a serem considerados nos projetos de irrigação para que os mesmos se tornem economicamente e ambientalmente sustentáveis.

\subsection{Impacto da disposição de efluentes no sistema solo-planta-ambiente}

\subsubsection{Efeitos nas características químicas e físicas do solo}

\subsubsection{1 pH do solo}

Normalmente, o pH da água de irrigação não tem afetado significativamente o pH do solo, por causa de seu poder tampão. Assim, não é de se esperar efeito direto do efluente no $\mathrm{pH}$ do solo, mesmo com a ocorrência generalizada de $\mathrm{HCO}_{3}{ }^{-}$(uma das

formas presentes de alcalinidade) nas águas residuárias. No entanto, existe a 
possibilidade dessa alcalinidade associada às altas concentrações de $\mathrm{Na}^{+} \mathrm{e}^{2} \mathrm{CO}_{3}^{2-}$, em águas alcalinas, ocasionar aumento do valor de pH do solo (Bouwer \& Idelovitch, 1987).

Tabela 1. Características típicas do efluente secundário de esgoto tratado no mundo.

\begin{tabular}{|c|c|}
\hline Constituinte & Variação \\
\hline & $\mathrm{mg} \mathrm{L}^{-1}$ \\
\hline Sólidos totais & $400-1200$ \\
\hline Sólidos suspensos & $10-100$ \\
\hline Sólidos dissolvidos & $400-1100$ \\
\hline DBO (demanda bioquímica de oxigênio) & $10-80$ \\
\hline DQO (demanda química de oxigênio) & $30-160$ \\
\hline Carbono orgânico total & $10-30$ \\
\hline N-total & $10-50$ \\
\hline $\mathrm{N}-\mathrm{NO}_{3}^{-}$ & $0-10$ \\
\hline $\mathrm{N}-\mathrm{NH}_{4}^{+}$ & $1-40$ \\
\hline P-total & $6-17$ \\
\hline $\mathrm{Cl}$ & $40-200$ \\
\hline Alcalinidade (como $\mathrm{CaCO}_{3}$ ) & $200-700$ \\
\hline $\mathrm{Na}$ & $50-250$ \\
\hline $\mathrm{K}$ & $10-40$ \\
\hline $\mathrm{Ca}$ & $20-120$ \\
\hline $\mathrm{Mg}$ & $10-50$ \\
\hline $\mathrm{B}$ & $0-1$ \\
\hline Concentração total de sais & $100-800$ \\
\hline $\mathrm{pH}$ & $7,8-8,1$ \\
\hline RAS (Razão de adsorção de sódio), em mmol L ${ }^{-1}$ & $4,5-7,9$ \\
\hline
\end{tabular}

Fonte: Bouwer \& Chaney (1974); Feigin et al. (1991).

No trabalho de Day et al. (1979) a irrigação com EET não alterou o pH do solo. Porém, nesta situação, tratava-se de um solo de região semi-árida, naturalmente alcalino. Por outro lado, Vazquez-Montiel et al. (1996) verificaram diminuição no pH em solo cultivado com milho e irrigado com EET. Os autores sugeriram que essa queda no $\mathrm{pH}$ do solo foi devido à nitrificação, uma vez que esse efeito foi incrementado mediante a adição de fertilizante nitrogenado mineral (sulfato de amônio).

Solos tratados com resíduos biodegradáveis (como o efluente de esgoto), mediante a degradação destes materiais pelos microrganismos, pode haver diminuição no valor de $\mathrm{pH}$ do solo devido a produção de $\mathrm{CO}_{2}$ e ácidos orgânicos (Bouwer \& 
Chaney, 1974). Porém, segundo Yan et al. (1996), a adição de resíduos orgânicos pode ocasionar aumento no $\mathrm{pH}$ do solo devido, principalmente, a dois diferentes processos: descarboxilação de ânions orgânicos, consumindo $\mathrm{H}^{+}$e liberando $\mathrm{CO}_{2}\left(\mathrm{R}-\mathrm{CO}-\mathrm{COO}^{-}+\right.$ $\mathrm{H}^{+} \rightarrow \mathrm{R}-\mathrm{CHO}+\mathrm{CO}_{2}$ ) e desaminação dos aminoácidos. Porém, a contribuição deste último processo é provavelmente de menor importância, pelo fato de o grupo aminoácido encontrar-se predominantemente protonado.

Tem sido observado em sistemas agrícolas (Johns \& McConchie, 1994a; At Nakshabandi et al.,1997), pastagens (Quin \& Woods, 1978; ) e florestas (Cromer et al., 1984; Stewart et al., 1990; Schipper et al., 1996; Smith et al., 1996b; Falkiner \& Smith, 1997; Speir et al., 1999), incremento no valor de pH do solo mediante a irrigação com água residuária. Este aumento de $\mathrm{pH}$ tem sido atribuído ao $\mathrm{pH}$ alto do efluente (Stewart et al., 1990); à adição de cátions trocáveis e de ânions oriundos do efluente (Falkiner \& Smith, 1997); à alteração na ciclagem de nutrientes mediante a adição de efluente, levando à redução do $\mathrm{NO}_{3}{ }^{-}$para $\mathrm{NH}_{4}{ }^{+}$e à denitrificação do $\mathrm{NO}_{3}{ }^{-}$, cujos processos produzem íons $\mathrm{OH}^{-}$e podem consumir prótons (Schipper et al., 1996).

Falkiner \& Smith (1997) não somente observaram aumento no valor de $\mathrm{pH}$ de solos irrigados com água residuária, mas também, verificaram diminuição do teor de $\mathrm{Al}$ trocável, devido ao aumento dos cátions trocáveis no solo $(\mathrm{Ca}, \mathrm{Mg}, \mathrm{K}$ e $\mathrm{Na})$ e da alcalinidade, adicionados pelo EET. Os mesmos autores também relataram que a capacidade de troca catiônica efetiva $\left(\mathrm{CTC}_{\mathrm{e}}\right)$ aumentou, e tal efeito foi atribuído a substituição de íons $\mathrm{H}^{+}$na superfície das argilas, devido a adição de $\mathrm{Ca}, \mathrm{Mg}, \mathrm{K}$ e $\mathrm{Na}$ e $\mathrm{HCO}_{3}{ }^{-}$pela água de irrigação (efluente). Johns \& McConchie (1994a), mediante uma regressão múltipla do $\mathrm{pH}$ e cátions trocáveis, demonstraram que o $\mathrm{pH}$ foi altamente afetado pelo $\mathrm{Na}$, havendo um incremento de 0,048 unidades de $\mathrm{pH}$ para cada mmol(+) $\mathrm{kg}^{-1}$ de Na presente na água residuária.

Apesar do EET poder contribuir para a elevação do pH do solo, tanto na camada superficial como no subsolo (Smith et al., 1996; Al-Nakshabandi et al., 1997), mais pronunciadamente em solos que receberam aplicação de eflue nte por vários anos (Quin \& Woods, 1978), este aumento de $\mathrm{pH}$ tem sido muito pequeno, da ordem de 0,1 a 0,8 unidades. Desse modo, os efeitos do aumento do pH do solo mediante adição de 
efluente de esgoto em solos ácidos, de baixa fertilidade natural, têm sido desprezíveis e de pouca importância prática com relação à disponibilidade de nutrientes (Speir et al., 1999). Então, não é de se esperar que o $\mathrm{HCO}_{3}{ }^{-}$ou certos compostos orgânicos presentes na água residuária, em concentrações variáveis, possa substituir a prática da calagem, apesar desse aumento de alcalinidade ser considerado vantajoso pelo fato de diminuir a mobilidade de metais pesados no solo (Stewart et al., 1990).

\subsubsection{Carbono e nitrogênio}

C e $\mathrm{N}$ orgânicos do EET são admitidos como sendo, principalmente, algas mortas com uma rápida velocidade de decomposição; então, a disposição de ESET no solo implica na adição de Norgânico e C-orgânico, os quais são adicionados como carboidratos na fração da matéria orgânica fresca (Snow et al., 1999).

Tem sido comum na literatura referências ao aumento nos teores de COT (carbono orgânico total) e NT (nitrogênio total) mediante a disposição de águas residuárias no solo, mais pronunciadamente em solos que vem recebendo efluentes por longo período. Quin \& Woods (1978) verificaram aumento nos teores de COT e NT, em pastagens irrigadas por mais de 16 anos com efluente. Latterell et al. (1982) observaram efeitos semelhantes após cinco anos de cultivo com milho irrigado com água residuária. Esse incremento nos teores de COT e NT têm sido comprovados pelo aumento na biomassa microbiana e na sua atividade, devido a adição de matéria orgânica facilmente decomponível e de nutrientes, mediante longo período de disposição de EET no solo (Friedel et al., 2000).

Apesar de Cromer et al. (1984) não terem observado em solos florestais nenhuma influência da irrigação com EET nos teores de NT, tem sido comum na literatura o aumento dos teores de $\mathrm{N}$-disponível, notadamente de $\mathrm{N}^{-\mathrm{NO}_{3}}{ }^{-}$, em solos que receberam águas residuárias, independentemente se em sistemas agrícolas (Feigin et al., 1978; Schalscha et al., 1979; Johns \& McConchie, 1994b), pastagens (Quin \& Forsythe, 1978; Linden et al., 1981; Lund et al., 1981) ou florestas (Polglase et al., 1995; Magesan et al., 1998; Smith \& Bond, 1999; Speir et al., 1999). 
Por outro lado, tem sido observado que a irrigação com efluente de esgoto pode aumentar a taxa de decomposição da matéria orgânica, notadamente em plantações florestais, podendo ocasionar diminuição nos teores de C e N do solo (Falkiner \& Smith, 1997). Pelo fato de a taxa de mineralização ser altamente dependente do potencial de água no solo (Stanford \& Epstein, 1974; Myers et al., 1982), o fator umidade constante (mediante irrigação) associado às altas temperaturas, promove uma rápida mineralização do material orgânico adicionado ao solo (Artiola \& Pepper, 1992). Assim, a irrigação com efluente tem o potencial de modificar os processos de ciclagem de $\mathrm{N}$ e também do C, por aumentar água no solo a teores que estimulam a atividade de decomposição da matéria orgânica (Polglase et al., 1995; Falkiner \& Smith, 1997).

$\mathrm{O}$ potencial de mineralização do $\mathrm{N}$ do solo é definido como a fração do $\mathrm{N}$ susceptível à mineralização, pressupondo que esta seja descrita por uma cinética de primeira ordem (Stanford \& Smith, 1972). Segundo Pöttker \& Tedesco (1979), tanto a incubação aeróbia como anaeróbia podem ser utilizadas nos estudos do N-orgânico, pois os resultados se correlacionam muito bem.

A mineralização do $\mathrm{N}$ depende da qualidade do material orgânico e da concentração de $\mathrm{N}$ no substrato (Janssen, 1996). A quantidade de N mineralizada no solo em um dado período, é dependente da temperatura, disponibilidade de água, taxa de reabastecimento de oxigênio, $\mathrm{pH}$, quantidade e natureza dos resíduos vegetais (Stanford \& Smith, 1972). Nos solos tratados com resíduos orgânicos, a mineralização do $\mathrm{N}$ além de ser altamente dependente da composição do resíduo e das características química e física do solo que receberá o resíduo (Chae \& Tabatabai, 1986), está diretamente relacionada à qualidade do material orgânico, por exemplo, relação C/N (Mengel, 1996).

No EET, a relação C/N normalmente é muito baixa, da ordem de 5/1 (Feigin et al., 1991) ou até menor do que 1/1 (Bouwer \& Chaney, 1974). Desse modo, espera-se que haja uma rápida mineralização do $\mathrm{N}$-orgânico do efluente e que o $\mathrm{N}$-efluente faça parte do ciclo do $\mathrm{N}$ tão logo que ele atinge o solo (Feigin et al., 1991). Assim, através da nitrificação, o amônio $\left(\mathrm{NH}_{4}^{+}\right)$do efluente, bem como o que derivou do $\mathrm{N}$-orgânico, é normalmente oxidado à nitrito $\left(\mathrm{NO}_{2}^{-}\right)$e rapidamente à nitrato $\left(\mathrm{NO}_{3}{ }^{-}\right)$. A amônia $\left(\mathrm{NH}_{3}\right)$, derivado do amônio, torna-se susceptível à volatilização em condições alcalinas e o $\mathrm{NO}_{3}{ }^{-}$ 
no solo, pode ser lixiviado da zona radicular (eventualmente para águas subterrâneas) ou pode ser denitrificado $\left(\mathrm{NO}_{3}{ }^{-} \rightarrow \mathrm{NO}_{2}{ }^{-} \rightarrow \mathrm{NO} \rightarrow \mathrm{N}_{2} \mathrm{O} \rightarrow \mathrm{N}_{2}\right)$.

Pelo fato de o ESET normalmente ser alcalino (Tabela 1), a volatilização de $\mathrm{NH}_{3}$ pode ser um importante caminho de perda de $\mathrm{N}$ nos solos irrigados com efluente. Assim, a concentração de Namoniacal no efluente, o pH da superfície do solo e a temperatura, são fatores que interferem diretamente no equilíbrio entre $\mathrm{NH}_{4}{ }^{+}$e $\mathrm{NH}_{3}$ na solução do solo e na quantidade potencial de $\mathrm{NH}_{3}$ a ser volatilizada (Smith et al., 1996a). Esses mesmos autores verificaram que a perda de $\mathrm{NH}_{3}$ mediante disposição de águas residuárias no solo é maior durante o dia (maiores temperaturas) e pode ser diminuída pela aplicação freqüente de pequena quantidade de efluente.

$\mathrm{O}$ predomínio do teor de $\mathrm{N}-\mathrm{NH}_{4}{ }^{+}$em relação ao de $\mathrm{N}-\mathrm{NO}_{3}{ }^{-}$, comum na maioria dos ESET (Tabela 1), torna-se vantajoso, uma vez que o $\mathrm{NH}_{4}{ }^{+}$quando infiltrado no solo, pode ser trocado e assim, ter a sua transformação no solo, pelos microrganismos, retardada (Hook, 1981). Hook \& Kardos (1978) verificaram que, em solos florestais irrigados com efluente, quando o teor de $\mathrm{N}^{-\mathrm{NO}_{3}}{ }^{-}$foi predominante no efluente, a lixiviação de $\mathrm{N}$ foi maior e quando o teor de amônio predominou no efluente, houve menor lixiviação de $\mathrm{N}$ no solo.

$\mathrm{A}$ adição do $\mathrm{N}$-efluente pode facilmente exceder o requerimento de $\mathrm{N}$ pelas plantas (Polglase et al., 1995). Overman (1981) observou que o aumento na taxa de aplicação de efluente aumentou o conteúdo de nutrientes e a produtividade do milho, mas ocasionou redução na quantidade de $\mathrm{N}$ recuperado. Menor quantidade de $\mathrm{N}$ recuperado significa maior potencial de lixiviação de $\mathrm{NO}_{3}{ }^{-}$, que normalmente tem sido alto nos solos irrigados com efluente (Schalscha et al., 1979; Smith \& Bond, 1999). Muitas das vezes, tem sido recomendado misturar água convencional ao ESET para evitar excesso de $\mathrm{N}$ disponível às plantas (Lurie et al., 1996).

Magesan et al. (1998) verificaram que a quantidade de $\mathrm{NO}_{3}{ }^{-}$no solo aumentou mediante o incremento da taxa de aplicação de efluente, pelo fato deste ser aplicado ao longo do ano e da demanda de $\mathrm{N}$ pelas árvores ser sazonal. Então, foi acumulado mais $\mathrm{N}$ no solo do que a quantidade desse nutriente requerida pelas plantas. No trabalho realizado por Schalscha et al. (1979), a irrigação com efluente de esgoto (contendo 32 
mg $\mathrm{L}^{-1}$ de $\mathrm{NO}_{3}{ }^{-}$) aumentou o teor de $\mathrm{N}^{-} \mathrm{NO}_{3}{ }^{-}$no solo para $16 \mathrm{mg} \mathrm{L}^{-1}$. Apesar do sistema solo-planta ter reduzido pela metade o teor deste ânion, o valor encontrado na solução do subsolo era acima do máximo permitido $\left(10 \mathrm{mg} \mathrm{L}^{-1}\right)$. No entanto, Quin \& Forsythe (1978) verificaram que a aplicação anual de $840 \mathrm{~mm}$ de EET (cujo teor de $\mathrm{N}$-total variou de 13,8 a 41,0 $\mathrm{mg} \mathrm{L}^{-1}$ ) levou ao aumento nos teores de $\mathrm{N}^{-\mathrm{NO}_{3}}{ }^{-}$e de outros nutrientes,

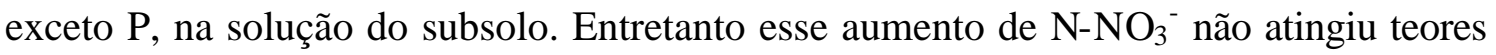
perigosos (Quin \& Woods, 1978).

Lund et al. (1981) verificaram que cerca de 51-76\% do $\mathrm{N}$ aplicado via efluente foi lixiviado, num perfil de 0-6 m de profundidade. Os autores atribuíram que essa lixiviação foi devido à aplicação relativamente alta de efluente em relação a demanda evapotranspirativa da cultura (pastagem), à textura do solo (grosseira, permitindo alta condutividade hidráulica e facilitando a lixiviação) e ainda, ao baixo potencial de denitrificação do solo. Porém, no trabalho de Linden et al. (1981), foi aplicada a mesma quantidade de efluente em todos os tratamentos, diferindo apenas o intervalo de aplicação. Os autores verificaram que embora a produção de forragem tenha sido a mesma, a concentração de $\mathrm{N}$ na solução do solo diminuiu pelo aumento da freqüência de irrigação. Então, não somente o quantidade de efluente aplicada tem influenciado a disponibilidade e migração de $\mathrm{N}$ no solo, mas também, a frequiência de aplicação do efluente.

Ao que parece, a denitrificação não tem sido suficiente para evitar que grande quantidade de $\mathrm{N}^{-} \mathrm{NO}_{3}{ }^{-}$atinja águas subterrâneas e assim, não constitui o mecanismo principal de perda de $\mathrm{N}$ nos solos irrigados com efluente (Lund et al., 1981; Smith \& Bond, 1999). Esse fato certamente ocorre tendo em vista que o solo raramente atinge o teor crítico de umidade, para tornar a aeração limitante e as condições adequadas para denitrificação, devido a sua drenagem natural (Smith \& Bond, 1999).

Porém, outros trabalhos contestam as afirmações de Lund et al. (1981) e Smith \& Bond (1999). Segundo Polglase et al. (1995), as perdas de N por denitrificação em solos irrigados com efluente (principalmente solos florestais) podem ser significantes, pois resíduos de plantas em decomposição podem liberar grandes quantidades de $\mathrm{C}$ solúvel, que associado ao potencial de nitrificação do solo e o efeito da 
irrigação no empobrecimento do $\mathrm{O}_{2}$, pode promover a denitrificação, minimizando as concentrações de $\mathrm{NO}_{3}{ }^{-}$no local. Friedel et al. (2000) verificaram aumento na atividade microbiana em solos agrícolas que receberam efluentes por longo período (mais de 80 anos) e ainda, a capacidade de denitrificação desses solos aumentou em mais de 50 vezes. Tal fato, segundo os autores, pode ter sido devido ao aumento, no solo, de surfactantes oriundos do efluente. No trabalho realizado por Schipper et al. (1996), foi observado que apesar de não ter ocorrido nenhum efeito maléfico nas propriedades bioquímicas de solos florestais irrigados com efluente (terciário), a taxa de denitrificação foi duas vezes maior. Os autores atribuíram esse fato à maior concentração de $\mathrm{N}_{-} \mathrm{NO}_{3}{ }^{-}$ no solo e ao aporte de $\mathrm{C}$ e água aplicados ao solo mediante irrigação com EET.

Desse modo, há uma estreita relação entre matéria orgânica disponível no solo e denitrificação (Feigin et al., 1991). O C-orgânico, adicionado pelo efluente ou produzido no solo pelas bactérias autotróficas, tem sido o principal fator na denitrificação, desde que este supra de energia as bactérias denitrificadoras (Bouwer \& Chaney, 1974). Assim, a adição de materiais orgânicos suprindo o C disponível aos microrganismos, tem resultado em freqüentes aumentos na taxa de denitrificação, constituindo-se em um importante processo de perda de $\mathrm{NO}_{3}{ }^{-}$nos solos que têm recebido efluentes.

O aumento na taxa de denitrificação ocasiona incremento na produção de NO e $\mathrm{N}_{2} \mathrm{O}$. Este processo muita das vezes é considerado benéfico ao sistema de tratamento de águas residuárias ao solo (Quin, 1978; Polglase et al., 1995; Schipper et al., 1996), porém esses gases ( $\mathrm{NO}$ e $\mathrm{N}_{2} \mathrm{O}$ ) têm efeitos deletérios ao ambiente. $\mathrm{O}$ NO caracteriza-se por ser um gás quimicamente reativo que regula a produção de ozônio na troposfera e é precursor da chuva ácida. $\mathrm{O} \mathrm{N}_{2} \mathrm{O}$ é um gás atuante no efeito estufa na troposfera e contribui para degradação da estratosfera (Hall \& Matson, 1999). Assim, é indesejável tanto a perda de $\mathrm{N}-\mathrm{NO}_{3}{ }^{-}$para águas subterrâneas quanto a sua denitrificação.

\subsubsection{Fósforo e enxofre}

A quantidade de $\mathrm{P}$ adicionado ao solo pela irrigação com efluente, normalmente não tem sido excessiva. Todavia, aumentos nos teores de $\mathrm{P}$ em solos 
irrigados com efluente de esgoto tem sido comuns, tanto em sistemas agrícolas (Schalscha et al., 1979; Latterell et al., 1982; Johns \& McConchie, 1994b), pastagens (Hortenstine, 1976; Quin \& Woods, 1978; Goh \& Condron, 1989) e florestas (Cromer et al., 1984; Stewart et al., 1990; Speir et al., 1999). Esses incrementos no teor de P tem sido observado principalmente na camada superficial do solo (Stewart et al., 1990; Johns \& McConchie, 1994b), mas também, no subsolo (Schalscha et al., 1979; Latterell et al., 1982; Al-Nakshabandi et al., 1997) e até na solução do solo (Hook, 1981; Johns \& McConchie, 1994b; Speir et al., 1999).

A disposição de EET no solo tem ocasionado aumento no teor de P-orgânico. Latterell et al. (1982) verificaram, em solo cultivado com milho, que o teor de Porgânico aumentou até $60 \mathrm{~cm}$ de profundidade, após cinco anos de irrigação com efluente. Os autores salientaram que apesar desse aumento ter sido significativo, foi muito pequeno se comparado ao teor de P inicial no perfil. Goh \& Condron (1989) avaliaram plantas de azevém cultivadas em solos irrigados por mais de 80 anos com efluente. Os autores verificaram que cerca de $40 \%$ do $\mathrm{P}$ do efluente encontravam-se na forma orgânica e assim, contribuiu grandemente para o aumento dos teores de Porgânico dos solos irrigados com efluente. Porém, os mesmos autores verificaram que a fração do P-orgânico era muito estável no solo e não foi capaz de suprir as plantas, uma vez que após três sucessivos cortes, as plantas de azevém removeram cerca de $13 \%$ do $\mathrm{P}$ orgânico e evidenciaram sintomas de deficiência desse nutriente.

A capacidade do solo em reter e lixiviar $\mathrm{P}$ e a capacidade de remoção deste nutriente pela vegetação foram avaliadas por Kardos \& Hook (1976); o estudo compreendeu dois sistemas com plantas forrageiras, sendo um para fenação e outro em rotação com milho; um sistema florestal e um sistema de campo nativo. Estes autores verificaram, nos quatro locais estudados, que após nove anos de irrigação com EET (com teor médio de 5-6 $\mathrm{mg} \mathrm{L}^{-1}$ de $\mathrm{P}$ ), $96 \%$ do $\mathrm{P}$ adicionado ainda se encontrava na camada $0-120 \mathrm{~cm}$; a penetração de $\mathrm{P}$ em camadas mais profundas estava diretamente relacionada ao menor teor de argila e de sesquióxidos do solo; e a lixiviação de $\mathrm{P}$ foi menor que $3 \%$ do total aplicado no sistema com floresta, e menor que $0,1 \%$ no sistema de rotação (forrageira/milho). 
Segundo Falkiner \& Polglase (1997) a capacidade do solo em reter P tem contribuído para prevenir que este nutriente não seja lixiviado abaixo da zona radicular, podendo determinar a sustentabilidade dos cultivos que utilizem irrigação com efluentes. Todavia, na aplicação de águas residuárias ao solo, é assumido que o P-efluente é altamente retido no solo. Mas estudos com solução de subsolos têm mostrado aumento na concentração de $\mathrm{P}$, embora muitas das vezes, esses incrementos do P-solução têm sido negligíveis (Johns \& McConchie, 1994b). No entanto, o aumento no teor de P na solução do subsolo tem evidenciado penetração do $\mathrm{P}$ aplicado ou mobilização do P existente no solo (Hook, 1981). Na revisão feita por Hook (1981), em várias situações de irrigação com efluente de esgoto, os teores de P ora variaram ora não variaram, na solução do subsolo. Nas situações de incremento dos teores de P na solução do subsolo, esse aumento foi menor que 5\% do total aplicado, indicando que, em muitos casos, um mínimo de $\mathrm{P}$ ultrapassou a profundidade $150 \mathrm{~cm}$. Todavia, os mecanismos que envolvem a migração de P-orgânico e a retenção de P inorgânico, em solos irrigados com efluentes deveriam ser melhor estudados (Falkiner \& Polglase, 1997), uma vez que em determinados tipos de solos (notadamente os arenosos) tem sido observado migração de $\mathrm{P}$ no perfil (Bond, 1998).

$\mathrm{O}$ movimento de $\mathrm{P}$ no sistema de tratamento de efluentes ao solo não é somente função das propriedades do solo e taxa de aplicação, mas também, do mane jo da vegetação, uma vez que o P absorvido pelas plantas não irá ser lixiviado no ambiente quando elas são colhidas e removidas do sistema (Hook, 1981). Hortenstine (1976) verificou, em um Espodossolo cultivado com Cynodon e irrigado com EET, que a camada espódica foi eficaz em reter P, mas não a camada superior desta. Isso mostrou que até mesmo os Espodossolos, desde que bem manejados, podem ser utilizados para disposição e renovação de águas residuárias.

Poucos tem sido os estudos de enxofre em solos irrigados com águas residuárias. No entanto, Johns \& McConchie (1994b) verificaram que a aplicação de EET ocasionou aumento nos teores de $\mathrm{S}$ até $50 \mathrm{~cm}$ de profundidade e ainda, aumentou o teor deste nutriente lixiviado na solução do solo. 


\subsubsection{Cálcio, magnésio e potássio}

Tem sido observado leve incremento nos teores de Ca trocável em solos que receberam EET, notadamente em solos florestais (Cromer et al., 1984; Speir et al.,1999) e pastagens (Quin \& Woods (1978), após longos períodos de irrigação.

Falkiner \& Smith (1997) verificaram aumento nos teores de Ca e Mg em solos irrigados com água residuária. Johns \& McConchie (1994b) verificaram que a irrigação com efluente ocasionou aumento nos teores de $\mathrm{Ca}$ até $50 \mathrm{~cm}$ de profundidade, não alterou o teor de Mg trocável, mas aumentou sua concentração lixiviada na solução do solo.

Com relação ao $\mathrm{K}$, os resultados encontrados na literatura são divergentes. Karlen et al. (1976) observaram que a aplicação de EET ocasionou aumento no teor de $\mathrm{Na}$ e consequentemente, diminuição do teor de K. Cromer et al. (1984) verificaram, em solos florestais irrigados por três anos com EET, que houve aumento no teor de $\mathrm{K}$ trocável. No trabalho realizado por Stewart et al. (1990), foi verificado redução no teor de $\mathrm{K}$ em profundidade (abaixo de $100 \mathrm{~cm}$ ). Evidentemente, a lixiviação de $\mathrm{K}$ está diretamente relacionada à CTC do solo. Johns \& McConchie (1994b) verificaram que apesar de os teores de $\mathrm{Ca}$ e $\mathrm{Na}$ trocáveis terem sido alterados pela irrigação com efluente, os teores de $\mathrm{Mg}$ e $\mathrm{K}$ trocáveis não foram influenciados. AlNakshabandi et al. (1997) verificaram aumento no teor de K até $60 \mathrm{~cm}$ de profundidade, após o cultivo de beringela. Falkiner \& Smith (1997) verificaram aumento no teor de K em solos que receberam efluentes e tal efeito foi atribuído a presença desse cátion no efluente.

Se o efluente for pobre em $\mathrm{K}$ e rico em $\mathrm{Na}$, para que sua disposição no solo seja sustentável, torna-se necessário a suplementação potássica para manter adequada a absorção de nutrientes e a produtividade das culturas e sobretudo, na cultura do milho (Karlen et al., 1976). Por outro lado, mesmo que ocorra aumento no teor de K disponível mediante a disposição de águas residuárias ao solo, a quantidade desse nutriente exigido pelas plantas é tão elevada que dificilmente somente a irrigação com efluente poderia suprir adequadamente as plantas (Feigin et al., 1991). 


\subsubsection{Micronutrientes e elementos tóxicos}

Tem sido relatado na literatura o aumento no teor de $\mathrm{CI}$ no solo mediante a irrigação com efluente de esgoto (Falkiner \& Smith, 1997) e mais pronunciadamente, se a irrigação for feita com ESET clorado. Pelo fato do CI ser um ânion de baixíssima retenção no solo, tem sido observado aumento no teor de Cl lixiviado na solução do solo nos locais que receberam águas residuárias (Johns \& McConchie, 1994b).

Os metais pesados encontram-se no efluente de esgoto tanto nos sólidos suspensos como na fração líquida. Os que se associam aos sólidos suspensos, acumulam-se na superfície do solo, ao passo que os metais pesados associados à fração líquida penetram no solo (Feigin et al., 1991).

Segundo McBride (1989), muitos estudos têm demonstrado a alta capacidade dos solos em reter metais pesados e, em síntese, devido à baixa solubilidade e alta adsorção específica desses metais, normalmente são encontrados baixos teores desses elementos em solução. O mesmo autor, considerou que, além das condições ácido-base do meio, os processos determinantes da solubilidade dos metais pesados no solo são: troca iônica nos argilominerais e óxidos; quimisorção na superfície do mineral; redução, precipitação e solução sólida; processos redox, levando-se em consideração a oxidação de metais, óxidos de metais e dissolução de metais por materiais orgânicos; adsorção de metais pela matéria orgânica; e especiação. A presença da matéria orgânica do solo tem afetado grandemente a solubilidade dos metais pesados (McBride, 1989). Os ácidos orgânicos, aminoácidos e ácidos fúlvicos, bem como sistemas biológicos e resíduos biológicos, influenciam a solubilidade dos metais pesados no solo (Feigin et al., 1991).

Mediante a disposição de EET no solo, ora tem havido aumento, ora tem ocorrido diminuição, ou mesmo, nenhuma influência da aplicação de água residuária (predominantemente doméstica) nos teores de metais pesados disponíveis no solo. Inglés et al. (1992) verificaram que a irrigação com efluente não afetou as concentrações de $\mathrm{Cd}$, $\mathrm{Ni}$ e $\mathrm{Pb}$ no solo, extraíveis em DTPA. Resultados semelhantes foram observados por Johns \& McConchie (1994a e 1994b), Al-Jaloud et al. (1995) e Smith et al. (1996b). Nos trabalhos de Johns \& McConchie (1994a e 1994b), foi evidenciado que os teores de As, $\mathrm{Cd}, \mathrm{Cr}$ e $\mathrm{Pb}$, em solos cultivados com bananeira e irrigados com efluente, não foram 
afetados. Al-Jaloud et al. (1995) verificaram, em solos cultivados com milho e irrigados com EET, que o teor de Ni não foi alterado. Também, Smith et al. (1996b) observaram, em solos florestais irrigados com água residuária por mais de quatro anos, que os teores de $\mathrm{Cr}, \mathrm{Ni}, \mathrm{Pb}$ e Zn extraíveis em EDTA não foram alterados pela irrigação com EET.

A disposição de EET no solo mediante irrigação de plantas, pode até ocasionar diminuição nos teores de metais pesados disponíveis no solo. Johns \& McConchie (1994b) verificaram que os teores de Fe diminuíram na superfície do solo, mas aumentaram em profundidade, mediante irrigação com efluente. Em outra situação, Al-Jaloud et al. (1995) verificaram que, em solos cultivados com milho e irrigados com efluente, os teores de $\mathrm{Cu}, \mathrm{Fe}, \mathrm{Mn}$ e $\mathrm{Zn}$ diminuíram. Em situações semelhantes, porém em outro experimento (com a cultura do sorgo), os mesmos autores verificaram que os teores de $\mathrm{Cu}, \mathrm{Fe}, \mathrm{Mn}$ e Ni no solo diminuíram, mediante aplicação de água residuária. Em solos florestais, Falkiner \& Smith (1997) verificaram que o incremento nos teores de $\mathrm{Ca}, \mathrm{Mg}, \mathrm{K}$ e $\mathrm{Na}$ e da alcalinidade, aplicados pelo efluente, promoveram aumento no valor de $\mathrm{pH}$ do solo e diminuição da disponibilidade de $\mathrm{Mn}$.

Por outro lado, Quin \& Syers (1978) verificaram que, pastagens irrigadas por 16 anos com EET, apresentaram ligeiro aumento nos teores de $\mathrm{Co}, \mathrm{Cu}, \mathrm{Mn}$ e $\mathrm{Zn}$ (extraídos em $\mathrm{HCl}$ 0,1 mol L ${ }^{-1}$ ). No entanto, segundo os autores, esse leve incremento na concentração de metais pesados no solo não influenciou a concentração desses metais na parte aérea das plantas. Inglés et al. (1992) observaram que o teor de Zn-DTPA aumentou e as plantas foram nutridas adequadamente com esse micronutriente, mediante irrigação com ESET. Johns \& McConchie (1994b) também observaram aumento nos teores de Zn mediante disposição de águas residuárias no solo, assim como o incremento nos teores de Fe, Mn e Ni na solução do solo. Al-Nakshabandi et al. (1997) verificaram aumento nos teores de $\mathrm{Cu}, \mathrm{Fe}, \mathrm{Mn}, \mathrm{Zn}, \mathrm{Cd}$ e $\mathrm{Pb}$ em solos irrigados com EET. Tais efeitos foram atribuídos à presença desses elementos no efluente utilizado para irrigação.

$\mathrm{Na}$ maior parte dos trabalhos que evidenciaram aumento nos teores de metais pesados no solo mediante irrigação com efluente, as observações referem-se a experimentos de longos períodos de aplicação de EET. Porém, o aumento desses metais no solo pela disposição de ESET não é fato tão preocupante assim. Segundo Bouwer \& 
Chaney (1974), seria necessário um século de irrigação com EET para que os teores de metais pesados atingissem valores equivalentes àqueles encontrados em um solo que recebeu aplicação de biossólido por apenas um ano. Evidentemente isso é variável em função da taxa de aplicação e da qualidade do biossólido. Porém, Friedel et al. (2000) verificaram que, em solos que receberam EET por mais de 80 anos, apesar de ter havido aumento nos teores totais de metais pesados, a qualidade biológica do solo não chegou a ser afetada. Então, é crucial o monitoramento dos teores de metais pesados ao longo do tempo em solos utilizados para propósito de disposição de resíduos (Cameron et al., 1997), inclusive, solos irrigados com EET (Bond, 1998).

\subsubsection{Salinidade, sodicidade e condutividade hidráulica}

Normalmente, pelo fato do efluente ser salino (Tabela 1), a irrigação com água residuária tem levado ao aumento da salinidade do solo (Cromer et al., 1984; Smith et al., 1996b), a qual pode afetar a absorção d'água pelas plantas devido a presença de uma maior concentração dos íons $\mathrm{Na}^{+}, \mathrm{Cl}$ e $\mathrm{HCO}_{3}{ }^{-}$na solução do solo (Bielorai et al., 1984).

Entretanto alguns autores têm assinalado diminuição na salinidade do solo pela irrigação com efluente (Day et al., 1979; Stewart et al., 1990). No primeiro caso, tratava-se de um solo naturalmente salino. No segundo, os autores verificaram que, em um solo florestal irrigado com EET por mais de quatro anos, a salinidade foi reduzida devido à lixiviação e à absorção (pelas árvores) de sais.

$\mathrm{O}$ aumento da condutividade elétrica (CE) do solo mediante a irrigação com efluente tem sido comum em sistemas agrícolas (Latterell et al., 1982; Johns \& McConchie, 1994b; Al-Nakshabandi et al., 1997), pastagens (Hortenstine, 1976) e florestas (Smith et al., 1996; Falkiner \& Smith, 1997; Speir et al.,1999), mais pronunciadamente na camada superficial do solo (Latterell et al., 1982; Al-Nakshabandi et al., 1997; Speir et al.,1999). Esse aumento de salinidade mais evidente na camada superficial do solo, pode ser, segundo Al-Nakshabandi et al. (1997), devido a dois fatores: evaporação da superfície do solo, levando ao acúmulo de sais; exposição do 
subsolo à contínua lixiviação e substituição dos sais na periferia da zona úmida, a qual, normalmente tem apresentado aumento na concentração de sais.

Aumentos no teor de Na trocável e no PST (percentual de sódio trocável) têm sido comum em solos irrigados com EET, independentemente se o uso for agrícola ou florestal (Feigin et al., 1991; Pescod, 1992; Bond, 1998), notadamente em experimentos de longa duração (Quin \& Woods, 1978; Balks et al., 1998). Latterell et al. (1982) verificaram que os teores de $\mathrm{Na}$ aumentaram de 3,5 até 25 vezes, em função da taxa de aplicação de efluente. Os aumentos no PST tem sido de 3,2 a 9,8\% (Stewart et al., 1990) até 22\% (Falkiner \& Smith (1997). Semelhantemente à salinidade, os principais efeitos do aumento do Na trocável, bem como do PST, tem sido mais evidentes na camada superficial do solo (Cromer et al., 1984).

Johns \& McConchie (1994b) verificaram que a irrigação com efluente não somente proporcionou aumento no teor de $\mathrm{Na}$ trocável, mas também, levou ao incremento no teor de Na lixiviado na solução do solo. No entanto, segundo os autores, essa entrada de $\mathrm{Na}$ (pela aplicação de efluente) não foi suficiente para substituir o Ca e o $\mathrm{Mg}$ na superfície dos colóides, tendo em vista que a lixiviação de Ca foi semelhante em todos os tratamentos irrigados, independentemente do tipo d'água de irrigação. No trabalho realizado por Stewart et al. (1990), a irrigação com efluente contendo 66,6$113,0 \mathrm{mg} \mathrm{L}^{-1}$ de $\mathrm{Na}$, apesar de ter levado ao aumento no teor de Na trocável, não alterou a distribuição de sais solúveis e dos cátions trocáveis no solo, mesmo havendo dominância de Na no efluente.

Balks et al. (1998) verificaram, em solos florestais irrigados com efluente rico em $\mathrm{Na}$, por cinco anos, que houve incremento do PST de 2 para 25\%. Os autores verificaram que o PST aumentou mais do que o previsto pela RAS (razão de adsorção de sódio) da irrigação com efluente, utilizando-se relações convencionais na literatura (Ayers \& Westcot, 1985). Esse aumento na sodicidade do solo contribuiu para que ocorresse dispersão de argila. Apesar disso, a diminuição na $\mathrm{CH}$ (condutividade hidráulica) do solo foi pequena, não afetandoo fluxo d'água. Segundo os autores, esse aumento no PST associado à pequena redução na $\mathrm{CH}$ do solo, não apresentou nenhuma ameaça para a continuidade da irrigação com efluente, uma vez que o solo não foi 
revolvido. Porém, a hipótese de ocorrência deste tipo de problema não pode ser descartada para experimentos de longa duração.

No trabalho de Speir et al. (1999), embora o teor de Na tenha aumentado pela aplicação de ESET, o inverso ocorreu quando a irrigação cessou, devido ao efeito das chuvas na lixiviação desse cátion. Os mesmos autores verificaram que tanto na camada superficial como no subsolo, a macro e microporosidade e a porosidade total não foram afetadas pela disposição de efluente no solo.

Todavia, os efeitos do $\mathrm{Na}$ em solo ácido de baixa CTC parece ser mais acentuado. Segundo Martin et al. (1964), a influência do Na em diferentes pH e o PST com base na CTC do solo, uma mesma quantidade de Na pode ocasionar maior efeito na redução da $\mathrm{CH}$ em um solo ácido do que neutro ou alcalino. Os mesmos autores observaram que o aumento nos teores de $\mathrm{Na}$ no solo influenciou o $\mathrm{pH}$ e a CTC do solo, principalmente no solo ácido e ainda, a $\mathrm{CH}$ diminuiu a medida que foi aumentado o PST na CTC, na $\mathrm{CTC}_{\mathrm{e}}$ e na relação com o somatório dos cátions trocáveis (Ca, $\mathrm{Mg}, \mathrm{K}$ e $\left.\mathrm{Na}\right)$.

Não somente o $\mathrm{Na}$ do efluente pode afetar a $\mathrm{CH}$ do solo. $\mathrm{O}$ impedimento hidráulico e a diminuição da taxa de difusão de $\mathrm{O}_{2}$ nos solos irrigados com água residuária também são dependente da qualidade do efluente (quantidade de sólidos suspensos e sólidos dissolvidos) e da taxa de aplicação (Oron et al., 1999). Apesar dos sólidos suspensos de origem orgânica presentes no efluente (flocos de bactérias, materiais fibrosos, algas, etc.) terem tamanhos reduzidos, quando associados à ação de bactérias e mediante a produção de polissacarídeos e outros compostos orgânicos, podem ocasionar entupimento biológico da superfície do solo (Bouwer \& Chaney, 1974). Evidentemente, a qualidade do efluente tem influenciado diretamente a sustentabilidade de sua disposição no solo.

\subsubsection{Efluente de esgoto tratado como fertilizante e efeitos na nutrição das plantas}

A quantidade de $\mathrm{N}$ adicionado ao solo através da irrigação com efluente pode ser similar ou até mesmo exceder a quantidade aplicada através da fertilização nitrogenada recomendada, durante períodos de tempo similares (Feigin et al., 1978). Em Israel, enquanto que a fertilização convencional de N para o algodão variou de 120 a 180 
$\mathrm{kg}$ de $\mathrm{N} \mathrm{ha}^{-1}$ ano $^{-1}$, a quantidade de $\mathrm{N}$ adicionado pela irrigação ESET nos experimentos com essa cultura, foi maior que $200 \mathrm{~kg} \mathrm{ha}^{-1}$ ano $^{-1}$ (Feigin et al., 1978 e 1984) e isso ocasionou aumento na concentração de $\mathrm{N}$ nas folhas das plantas (Feigin et al., 1984). Feigin et al. (1978) verificaram que a quantidade de $\mathrm{N}$ adicionado ao capim de Rhodes pela irrigação com ESET foi aproximadamente $500 \mathrm{~kg} \mathrm{ha}^{-1} \mathrm{ano}^{-1}$.

Day et al. (1974) observaram, na cultura do trigo forrageiro, que as plantas irrigadas com EET foram mais eficientes em recuperar o $\mathrm{N}$ do efluente, quando comparado às plantas adubadas com fertilizantes minerais. Porém, Feigin et al. (1981) estudando a eficiência de uso do nitrogênio (EUN) em plantas de milho irrigadas com EET, verificaram que a absorção de $\mathrm{N}$ não foi afetada pela qualidade da água de irrigação, mas a disponibilidade do N-efluente foi um pouco menor que a fertilização nitrogenada incorporada ao solo. Os autores atribuíram esse fato às perdas por volatilização, uma vez que mediante a irrigação com efluente, os nutrientes são deixados na superfície do solo.

Essa menor eficiência do EET como fertilizante (particularmente como fonte de $\mathrm{N}$ ), pode provocar deficiência nutricional e/ou reduzir a produtividade da cultura, particularmente no milho, onde o desenvolvimento da espiga é dependente, acima de tudo, do adequado armazenamento de nutrientes nas folhas e colmos, para posteriormente serem translocados às espigas (Overman et al., 1995). Por outro lado, a irrigação com água residuária tem aumentado a absorção de $\mathrm{N}$ e $\mathrm{P}$ pelas plantas de milho e também, ocasionado aumento na produtividade (Vazquez-Montiel et al., 1996). Porém, neste último caso, a cultura inicialmente tinha recebido a adição de fertilizantes minerais. Assim, a dependência total de nutrientes oriundos do efluente pode levar a ocorrência de carências nutricionais e reduzir a produtividade das culturas (Inglés et al., 1992; Maurer \& Davies, 1993), inclusive no milho (Overman et al., 1995).

Quanto a nutrição das plantas irrigadas com água residuária, Bole \& Bell (1978) observaram que a aplicação de EET não afetou os teores de $\mathrm{Mg}, \mathrm{Cu}, \mathrm{Fe}, \mathrm{Mn}$ e Zn nas plantas forrageiras Medicago sativa, Phalaris arundinacea, Bromus inermis, Elymus angustus e Agropyron elongatum. Com exceção do N, todos os demais nutrientes foram adequadamente supridos às plantas mediante a irrigação com efluentes, inclusive o P. 
Porém, tratava-se de solo com alta fertilidade e o maior limitante era a água, a qual foi suprida mediante irrigação com efluente.

Em um estudo de longa duração (16 anos), Quin \& Syers (1978) verificaram que os teores de $\mathrm{Pb}, \mathrm{Zn}, \mathrm{Cd}, \mathrm{Cr}, \mathrm{Ni}, \mathrm{Co}, \mathrm{Cu}, \mathrm{Mn}$ e $\mathrm{Sr}$ nas folhas de azevém perene, bem como a relação $\mathrm{Cd} / \mathrm{Zn}$, não foram alterados pela irrigação com efluente de esgoto. Pelo fato do $\mathrm{Cd}$ estar química e geoquimicamente relacionado ao $\mathrm{Zn}$ e ainda, por serem tóxicos quando em altas concentrações, esses os dois elementos têm sido monitorados juntos. Assim a relação $\mathrm{Cd} / \mathrm{Zn}$ tem sido utilizada para saber se o Cd está sendo acumulado em algum local particular na cadeia alimentar (Quin \& Syers, 1978).

Cromer et al. (1984) verificaram, em solos florestais irrigados por três anos com EET, que os teores foliares $\mathrm{P}$ e $\mathrm{K}$, no pinus, aumentaram, em decorrência do aumento desses nutrientes no solo.

Nas culturas do aipo, brócolis, repolho e couve-flor, Burau et al. (1987) verificaram, em um estudo de cinco anos, que os teores de metais pesados $\mathrm{Cd}, \mathrm{Co}, \mathrm{Cr}$, $\mathrm{Cu}, \mathrm{Fe}, \mathrm{Ni}, \mathrm{Mn}, \mathrm{Pb}$ e $\mathrm{Zn}$ não foram afetados pela irrigação com efluente. Inglés et al. (1992) verificaram que a absorção de $\mathrm{Fe}, \mathrm{Mn}, \mathrm{Cu}$ e $\mathrm{Zn}$ pelo tomateiro foi aumentada mediante irrigação com efluentes. Porém, o $\mathrm{Cd}$ não foi detectado e o $\mathrm{Ni}$ foi aumentado somente nas raízes, tanto pela irrigação com EET como também nos tratamentos que receberam fertilizantes. Os mesmos autores verificaram que as concentrações de $\mathrm{Cd}, \mathrm{Ni}$ e $\mathrm{Pb}$, na parte aérea não foram influenciadas pelos tratamentos.

Gadallah (1994) estudaram o efeito da irrigação com efluente de esgoto na cultura do girassol. $\mathrm{O}$ autor verificou que as plantas tiveram teores de foliares de $\mathrm{Ca}, \mathrm{Mg}$ e $\mathrm{Cl}$ mais elevados e que, o teor de $\mathrm{P}$ nas folhas foi menor que o de $\mathrm{Cl}$. Quanto às raízes, foi observado aumento nos teores de $\mathrm{Zn}, \mathrm{Mn}$ e $\mathrm{Na}$ e o aumento desse último elemento levou às plantas a acumularem menos $\mathrm{K}$. Neste mesmo trabalho, foi verificado que as plantas tratadas com efluente apresentaram menores teores de elementos inorgânicos, devido às alterações desproporcionais no crescimento e absorção de nutrientes. Também, não houve correlações entre os teores de metais no efluente e nas plantas, devido a variação dos mesmos na água residuária. 
Johns \& McConchie (1994a) verificaram, na bananeira, que apesar de a irrigação com EET ter aumentado o teor de Na no solo, a concentração desse elemento nas folhas não foi afetada na mesma proporção. Porém, o B teve sua concentração foliar aumentada pela disposição de água residuária no solo. No mesmo experimento, Johns \& McConchie (1994b) verificaram que a irrigação com efluente não afetou o tamanho das plantas. No entanto, a composição química das mesmas foram afetadas. Assim elas absorveram a mais $225 \%$ de $\mathrm{Na}, 81 \%$ de $\mathrm{B}, 43 \%$ de $\mathrm{Cu}, 26 \%$ mais $\mathrm{Cl}$ e $16 \%$ de $\mathrm{N}, \mathrm{P}$ e K e ainda, a absorção de Ni foi diminuída em $40 \%$.

Al-Jaloud et al. (1995) verificaram que as concentrações de N, P, K, Mg, Na, $\mathrm{Cu}, \mathrm{Mn}$, Mo e $\mathrm{Zn}$ nas folhas de milho aumentaram mediante a irrigação com EET. Os mesmos autores verificaram que 82 a $99 \%$ da variabilidade na concentração desses minerais nas plantas foram afetados pela qualidade da água de irrigação, ou seja, foram os teores desses nutrientes no efluente que influenciaram a nutrição das plantas de milho. Em outro experimento, porém, com a cultura do sorgo, Al-Jaloud et al. (1995) observaram aumento nas concentrações foliares de N, Ca, $\mathrm{Mg}$ e $\mathrm{Na}$, mediante a irrigação com EET e também, diminuição nas concentrações de $\mathrm{P}$ e $\mathrm{K}$. $\mathrm{O}$ aumento nas concentrações de $\mathrm{N}, \mathrm{Ca}$ e $\mathrm{Mg}$, segundo os autores, foi em resposta à salinidade. Também, a análise de correlação indicou que 74 a 97\% da variação desses nutrientes foi devido à irrigação com água residuária.

Al-Nakshabandi et al. (1997) verificaram aumento nas concentrações de N, P, $\mathrm{K}, \mathrm{Na}$, Ca e Mg, nas folhas e nos frutos de beringela, mediante a irrigação com efluente. Esses efeitos foram atribuídos a presença desses nutrientes no efluente. Os mesmos autores também verificaram aumento, porém irrisório, nos teores de $\mathrm{Zn}, \mathrm{Mn}, \mathrm{Cd}, \mathrm{Cr}$ e $\mathrm{Pb}$, nas folhas.

Flores Tena et al. (1999) verificaram que águas residuárias ricas em $\mathrm{Cr}$ e $\mathrm{Pb}$ ocasionaram aumento no conteúdo desses metais pela alfafa. Os mesmos autores observaram que as concentração desses metais nos tecidos vegetais encontravam-se diretamente relacionadas aos seus respectivos teores no solo. 


\subsubsection{Efeitos na produtividade das culturas}

\subsubsection{Grandes culturas}

Vários trabalhos têm demonstrado o potencial de utilização de EET na cultura do algodão (Day et al., 1981; Bielorai et al., 1984; Oron et al., 1999). Segundo Feigin et al. (1984) a irrigação por gotejamento, com efluente de esgoto, pode ser utilizada com sucesso no algodão, mas deve-se ter o cuidado de adequar o período de irrigação para evitar o excesso de crescimento das plantas. Os mesmos autores verificaram que a combinação de uma taxa relativamente alta d'água e de $\mathrm{N}$, ambos do EET, foi responsável pelo aumento da produção de algodão. No entanto, nas maiores taxas de aplicação de efluente pode haver maior período ve getativo, excesso de crescimento e diminuição na produção de línter, devido ao excesso de N e à aplicação d'água (Bielorai et al., 1984). Day et al. (1981) verificaram que os melhores resultados de produtividade do algodão foram obtidos com a mistura (1:1) de água convencional com água residuária, pelo fato de a mistura ter reduzido os teores de sais solúveis e assim, ocasionou aumento na qualidade das fibras.

Al-Jaloud et al. (1996) observaram maior produtividade da canola quando esta cultura foi irrigada com EET. Segundo os autores, esse efeito não somente foi devido ao $\mathrm{N}$, mas também, aos demais nutrientes contidos na água residuária. E ainda, para uma produtividade de 3,78 $\mathrm{t} \mathrm{ha}^{-1}$ (MET - máxima eficiência técnica), economizaram-se 150 $\mathrm{kg} \mathrm{ha}^{-1}$ de $\mathrm{N}$ mediante a irrigação das plantas com efluente de esgoto.

Os cereais de inverno têm tido bons resultados à aplicação de EET. As culturas de aveia, cevada e trigo, quando irrigadas somente com efluente, não tiveram seus teores de proteína e produtividades diferentes das plantas fertilizadas e irrigadas com água convencional (Day et al. (1962). Em outro experimento, a cevada teve sua produtividade aumentada, mas a qualidade do malte foi reduzida, certamente, devido ao excesso de N ocasionado pelo efluente (Day et al., 1963). Os autores sugeriram que, nessa situação, seria interessante a mistura de água convencional à água residuária. Mas no estudo realizado por Hussain \& AlJaloud (1998), também com cevada, a irrigação com EET levou a uma economia da ordem de 50-75\% de fertilizante nitrogenado, 
mantendo-se o mesmo patamar de produtividade daquelas plantas fertilizadas com adubo nitrogenado mineral (uréia) e irrigadas com água convencional.

Day et al. (1974) observaram que plantas de trigo irrigadas com efluente tiveram maiores diâmetro de colmos, teor de fibra, produtividade e teor de proteína e ainda, a aplicação de água residuária não teve efeito adverso no perfilhamento. Em outros dois experimentos, Day et al. (1975) verificaram que a altura das plantas, o número de sementes por espiga, o peso das sementes e os teores de fibra total, proteína e de nucleotídios ácido-solúveis não foram influenciados pela aplicação de efluente. No entanto, o número de espigas por área e, consequentemente, a produção de grãos de trigo, foram aumentados.

Em um outro estudo realizado por Day et al. (1979), foi observada maior produção de espigas por área, sementes mais pesadas, maior produtividade de grãos e de matéria seca pela cultura do trigo irrigado com a mistura água convencional mais EET (1:1). Porém, Hussain et al. (1996) verificaram que, em duas safras com trigo irrigado somente com EET (teor médio de $20 \mathrm{mg} \mathrm{L}^{-1}$ de $\mathrm{N}$-total), houve maior produtividade das plantas, maior EUN e ainda, que esse incremento de produção não foi somente devido ao $\mathrm{N}$, mas também, aos demais nutrientes contidos no efluente. Os mesmos autores observaram que o uso de água residuária na irrigação do trigo levou a uma economia de 1/3 da fertilização nitrogenada mineral. Desse modo, o EET tem se mostrado efetivo como fonte parcial de nutrientes e água para lavouras de trigo, com o intuito de obtenção de alta produtividade (Day et al., 1974, 1975 e 1979; Hussain et al., 1996).

Day \& Tucker (1977), estudando a cultura do sorgo irrigado com EET e água convencional, verificaram que as plantas apresentaram altura, número de perfilhos, peso de 1000 sementes, teor de proteína, largura e comprimento das folhas semelhantes. No entanto, as plantas produziram mais com o uso de EET. Al-Jaloud et al. (1995) verificaram que apesar da concentração de $\mathrm{Na}$ ter sido mais elevada nas plantas de sorgo, mediante a irrigação com água residuária, a produção de matéria seca aumentou com o aumento da concentração de $\mathrm{Na}$ e salinidade da água (efluente). O aumento na produtividade de sorgo mediante a aplicação de água residuária tem sido atribuído à presença de outros elementos nutrientes existentes no efluente (Day \& Tucker, 1977), os 
quais também podem neutralizar o efeito adverso da alta concentração de Na na água de irrigação (Al-Jaloud et al., 1995).

Vários trabalhos têm relatado bons resultados da aplicação de EET na cultura do milho, ocasionando aumentos na produção de grãos (Karlen et al., 1976; VazquezMontiel et al., 1996; Oron et al., 1999) e de matéria seca ou silagem (Karlen et al., 1976; Overman, 1981; Al-Jaloud et al., 1995). Al-Jaloud et al. (1995) verificaram que apesar da concentração de $\mathrm{Na}$ ter sido elevada nas plantas de milho, mediante a irrigação com efluente, a produção de matéria seca aumentou com o incremento da concentração de $\mathrm{Na}$ e da salinidade da água (efluente). O aumento na produção de milho mediante a irrigação com EET tem sido devido ao incremento na taxa de aplicação de efluente, promovendo maior aporte de nutrientes (Overman, 1981); à maior absorção de nutrientes e sobretudo, de N e P (Vazquez-Montiel et al., 1996); e à presença de outros elementos nutrientes no efluente, os quais podem neutralizar o efeito indesejável da alta concentração de Na na água residuária (Al-Jaloud et al., 1995).

\subsubsection{Plantas olerícolas e frutíferas}

Schalscha et al. (1979) verificaram que o aumento na disponibilidade de $\mathrm{N}$ e $\mathrm{P}$, devido à irrigação com efluente, refletiu diretamente na produção de hortaliças (alface, aipo, pepino, cebola) e também, na produção de trigo. No entanto, surgiram alguns problemas cruciais, tais como conflitos de ordem ambiental (excesso de $\mathrm{N}^{-\mathrm{NO}_{3}}{ }^{-}$ em águas subterrâneas) e de saúde humana (doenças). No entanto, Burau et al. (1987) estudando a disposição de efluentes (incluindo ESET filtrado) e taxas de fertilização em hortaliças (aipo, brócolis, repolho e couve-flor), em um experimento de cinco anos de duração, obtiveram resultados completamente diferentes dos obtidos por Schalscha et al. (1979). Burau et al. (1987) verificaram que as concentrações de vírus, coliformes totais e fecais, e o período de armazenamento das hortaliças, não foram afetados pelo uso de ESET. Ainda, os autores também relataram que a produtividade das culturas foi aumentada devido aos nutrientes contidos no efluente.

Todavia, não tem sido recomendada a aplicação de EET em culturas folhosas consumidas in natura, evidentemente, pelo contato direto do efluente com a parte 
comestível, levando ao aumento da probabilidade de risco de saúde (Feigin et al., 1991; Pescod, 1992). No entanto, nas olerícolas não folho sas, cuja parte comestível tem sido o fruto, quando essas plantas têm recebido irrigação com EET, principalmente por gotejamento (Pescod, 1992), tem havido sucesso tanto no aspecto ambiental como econômico. Desse modo, tem sido observado aumentos na produtividade de tomate (Inglés et al., 1992) e de beringela (Al-Nakshabandi et al., 1997), devido à contribuição dos nutrientes presentes no EET, principalmente $\mathrm{N}, \mathrm{P}$ e K.

A literatura também relata que as frutíferas vem obtendo sucesso na irrigação com EET (Maurer \& Davies, 1993; Lurie et al., 1996), sem maiores efeitos deletérios nas plantas e no ambiente e ainda, tem havido economia de fertilizantes minerais (Fitzpatrick et al., 1986). Johns \& McConchie (1994a) verificaram que a cultura da banana foi $10 \%$ mais produtiva mediante irrigação com água residuária. Neste mesmo experimento, também foi observado que a aplicação de $600 \mathrm{~mm}$ de EET atendeu $20 \%$ do total de $\mathrm{N}$ requerido pela bananeira, sem ocasionar dano ambiental (Johns \& McConchie, 1994b).

\subsubsection{Plantas forrageiras}

As plantas forrageiras pelo fato de apresentarem longa estação de crescimento, elevado acúmulo de nutrientes e pela sua capacidade de recobrimento do solo, têm tido alto potencial para receber a aplicação de efluentes (Bole \& Bell, 1978).

Tem sido observado sucesso na produção de forragens irrigada com EET, visando o fornecimento de água e nutrientes (Day \& Tucker, 1960). Assim, vários experimentos têm mostrado a possibilidade de obtenção de alta produtividade e qualidade nas culturas de alfafa (Bole \& Bell, 1978; Day et al., 1982; Darwish et al., 1999), aveia forrageira (Day \& Tucker, 1959), azevém perene (Quin \& Syers, 1978; Quin \& Woods, 1978), capim de Rhodes (Feigin et al., 1978; Vaisman et al., 1981), capim napier (Jeyaraman, 1988), milho forrageiro (Overman \& Nguy, 1975; Karlen et al., 1976; Overman, 1981) e trigo forrageiro (Day \& Tucker, 1959; Day et al., 1974), mediante irrigação com água residuária. Porém, a cevada forrageira foi $22 \%$ menos

produtiva quando irrigada somente com efluente (Day \& Tucker, 1959) e tal fato, 
segundo os autores, foi atribuído à presença de detergentes e de alta concentração de sais solúveis na água residuária.

Dentre as plantas forrageiras, a alfafa tem tido boas respostas, tanto em termos de produtividade de matéria seca como de proteína, mediante a irrigação com água residuária pura (Bole \& Bell, 1978) ou misturada à água convencional (Day et al., 1982). Essa alta produtividade da alfafa nos sistemas de aplicação de efluentes ao solo, tem sido atribuído à sua elevada absorção de N (Darwish et al., 1999), permitindo alta taxa de aplicação de efluentes por área e também, quando o efluente aplicado é pobre em N, esta planta tem sido produtiva por causa da simbiose com bactérias fixadoras de $\mathrm{N}$ (Bole \& Bell, 1978). Assim, Bole \& Bell (1978) estudaram, por quatro anos, o efeito da adição de EET em um sistema solo-pastagem cultivado com as forrageiras Medicago sativa, Phalaris arundinacea, Bromus inermis, Elymus angustus e Agropyron elongatum. Os autores verificaram que a alfafa foi a cultura que apresentou rendimento médio mais elevado, independentemente se o solo era ou não fertilizado. Esse fato ocorreu porque o efluente foi incapaz de nutrir adequadamente as plantas com $\mathrm{N}$ e a alfafa, por causa da sua "auto-suficiência", foi a mais produtiva.

Com relação ao milho forrageiro, Overman \& Nguy (1975) verificaram que a produção de matéria seca, taxa de acumulação de proteína e absorção de $\mathrm{N}$ aumentaram mediante a taxa de irrigação com EET (contendo em média $37 \mathrm{mg} \mathrm{L}^{-1}$ de $\mathrm{N}$-total). Os mesmos autores também verificaram que, em solo arenoso, o percentual de recuperação de $\mathrm{N}$ foi maior na menor taxa de aplicação (50 mm semana ${ }^{-1}$ ), enquanto que na maior taxa (200 mm semana ${ }^{1}$ ) a eficiência de recuperação do $\mathrm{N}$ do efluente foi de $50 \%$ e certamente, incrementou os teores de $\mathrm{N}$ nas águas subterrâneas.

O capim de Rhodes tem recebido atenção particular quando este é destinado à renovação de águas residuárias. Esta cultura tem aumentado sua produtividade tanto pela adição de EET (Feigin et al., 1978; Vaisman et al., 1981) como também, pelo aumento na freqüência de irrigação com águas residuárias (Feigin et al., 1978). O aumento na freqüência de irrigação tem diminuído a lixiviação de $\mathrm{N}$ (Linden et al., 1981) e incrementado a absorção d'água e deste nutriente, o que evidentemente implica em menor quantidade de fertilizante nitrogenado para obtenção da MET (Feigin et al., 1978; 
Vaisman et al., 1981). Feigin et al. (1978) observaram que mesmo recebendo a maior carga de efluente, o capim de Rhodes foi o mais eficiente na remoção do N-efluente, quando comparado as culturas de beterraba açucareira e algodão. Esta gramínea não somente tem sido efetiva na remoção do N-efluente, mas também, tem evitado o risco de poluição com $\mathrm{N}^{-\mathrm{NO}_{3}}{ }^{-}$(Vaisman et al., 1981). Então, solos irrigados com EET podem apresentar melhores produtividades, utilizando-se menos fertilizantes, com menor probabilidade de efeitos detrimentais na qualidade da produção e na poluição de águas (Feigin et al., 1978).

\subsubsection{Florestamentos}

A irrigação de árvores tem se tornado uma forma usual de disposição de efluentes pelas seguintes razões: não fazem parte da cadeia alimentar dos humanos; apresentam alta absorção de água quando comparado as outras plantas (requerem menos solo para um dado volume de água residuária); criam uma "imagem verde" (Smith \& Bond, 1999).

Falkiner \& Smith (1997) verificaram que embora a salinidade do solo tenha aumentado, mediante irrigação com EET, isso não foi suficiente para afetar o pinus e o eucalipto. Este fato certamente foi devido a outros benefícios que a disposição que efluentes tem ocasionado ao sistema solo-planta, como a presença de nutrientes no efluente (Bouwer \& Chaney, 1974; Feigin et al., 1991; Pescod, 1992), os quais também podem neutralizar o efeito adverso de certos elementos maléficos (como o $\mathrm{Na}$ e sais) (Al-Jaloud et al., 1995).

Porém, após o fechamento de copas, a ciclagem de nutrientes (principalmente a biogeoquímica), tem sido o maior responsável pelo fornecimento de nutrientes ao sistema solo-floresta (Gonçalves et al., 2000). Então, o aporte externo de nutrientes, bem como a disposição de efluentes, pode influenciar a mineralização da matéria orgânica do solo e com isso, ocasionar desestabilização do ecossistema, uma vez que o EET tem influenciado diretamente os ciclos do C e N (Polglase et al., 1995; Falkiner \& Smith, 1997). Hook \& Kardos (1978) verificaram que, em florestas irrigadas por nove anos com EET, ocorreram lixiviação de $\mathrm{N}$ nos últimos sete anos de irrigação (provável estádio de 
crescimento após o fechamento de copas) e as árvores foram incapazes de remover o $\mathrm{N}$ adicionado via $50 \mathrm{~mm}$ semanal de irrigação. Assim, o teor de $\mathrm{N}_{-} \mathrm{NO}_{3}{ }^{-}$nas águas subterrâneas era maior que $10 \mathrm{mg} \mathrm{L}^{-1}$.

Segundo Polglase et al. (1995) a irrigação de plantações com EET afeta o crescimento das árvore e a absorção de $\mathrm{N}$, o turnover do $\mathrm{N}$ no solo, denitrificação e, se o efluente for alcalino, promove volatilização de $\mathrm{N}-\mathrm{NH}_{3}$. Ainda, segundo os autores, as taxas de ciclagem de $\mathrm{N}$ no EET, em plantações irrigadas podem ser modificadas por fatores específicos do local, como clima, tipo de solo, química do efluente, escolha de espécies arbórea, estádio de desenvolvimento das árvores e stand, práticas de manejo do povoamento e da irrigação.

\subsection{Sustentabilidade da irrigação de plantas com efluente de esgoto tratado}

Embora não tenha sido objetivo do presente trabalho enfocar os aspectos epidemiológicos, torna-se necessário comentar brevemente os possíveis risco de saúde ocasionados pela irrigação de plantas com efluente de esgoto. Desse modo, Shuval et al. (1985) sumariaram os estudos epidemiológicos disponíveis sobre o uso de águas residuárias na agricultura e chegaram às seguintes considerações:

a) A irrigação de lavouras com água residuária sem tratamento prévio provoca, nos consumidores e nos agricultores, aumento de infecções endêmicas por nematóides intestinais;

b) A irrigação de cultivos com EET ocasiona, aos agricultores e aos consumidores dos produtos, poucas infecções intestinais por nematóides;

c) A cólera e a febre tifóide podem ser transmitidas através da irrigação de verduras com efluente de esgoto sem tratamento prévio;

d) A irrigação de plantas forrageiras com efluentes sem tratamento prévio pode infectar o rebanho com Cysticercus bovis (estádio larval da Taenia saginata de bovinos);

e) Há evidências de que nas comunidades com bons hábitos higiênicos, a saúde dos habitantes próximos às áreas irrigadas com água residuária sem tratamento prévio pode ser afetada pelo contato direto com o solo ou pelo contato com os agricultores; 
f) A aplicação de efluentes mediante irrigação por aspersão pode disseminar vírus e bactérias. Porém, não foi detectado risco real de transmissão de enfermidades por essa via. Todavia, recomenda-se um afastamento mínimo de 50 a 100m entre a área irrigada com EET e casas ou vias de domínio público.

A disposição de águas residuárias no solo mediante a irrigação de plantas tem afetado as características químicas, físicas e biológicas do solo; a nutrição e produtividade das culturas; e ainda, o ambiente (Bouwer \& Chaney, 1974; Feigin et al., 1991; Pescod, 1992; Bond, 1998). Esses fatores associados com o provável aumento, no futuro, da área irrigada com efluente e da quantidade de água residuária gerada, evidenciam o surgimento paralelo de novos problemas (Bouwer, 2000).

Portanto, na irrigação sustentável com EET, é de fundamental importância, além do conhecimento das propriedades do efluente (Bouwer \& Idelovitch, 1987), entender o impacto de sua disposição no sistema solo-planta-ambiente (Cameron et al., 1997; Bond, 1998). Nos locais onde for planejada e utilizada a irrigação com efluentes, estudos cautelosos devem ser feitos para averiguar o potencial de efeitos na água subterrânea, especialmente se esta for utilizada para propósito de água para consumo humano (Bouwer, 2000).

Não é possível, mediante o tratamento de efluentes no sistema solo-planta eliminar completamente o problema de lixiviação de sais para águas subterrâneas, mas sim, remediá-lo (Vaisman et al., 1981). Na ocasião, os autores estudaram uma área de pastagem com capim de Rhodes que recebeu EET. Eles concluíram que apesar da cultura ter sido eficiente na redução dos poluentes (nutrientes), por absorvê-los e convertê-los em matéria seca, ainda houve migração de sais e nutrientes, inclusive de N$\mathrm{NO}_{3}{ }^{-}$para águas subterrâneas. Evidentemente, essa lixiviação de $\mathrm{N}-\mathrm{NO}_{3}{ }^{-}$ocorreu à teores abaixo do permitido (menor que $10 \mathrm{mg} \mathrm{L}^{-1}$ ).

Bond (1998) ressaltou que o monitoramento adequado e a avaliação das informação coletadas, é a chave do sucesso do manejo sustentável da irrigação com efluente. Para essa meta ser atingida, o autor ressalta que é necessário o monitoramento do crescimento das plantas; da incidência de pragas e doenças; da dinâmica da água e alterações nas propriedades físicas do solo; da quantidade de $\mathrm{P}$, sais, $\mathrm{Na}$ e metais 
pesados acumulados no solo; dos teores de $\mathrm{N}_{-} \mathrm{NO}_{3}{ }^{-}$e outros contaminantes móveis presentes no efluente para águas subterrâneas.

$\mathrm{O} \mathrm{N}$ é o maior fertilizante, bem como o maior fator ambiental em solos irrigados com águas residuárias (Feigin et al., 1978). Assim, o entendimento das transformações do N-efluente no solo e o manejo deste nutriente são fatores essenciais para a sustentabilidade da irrigação com efluente (Bond, 1998). A absorção deste nutriente pelas plantas é um fator muito importante, uma vez que é desejável a remoção/absorção deste nutriente para evitar a lixiviação de $\mathrm{N}_{-} \mathrm{NO}_{3}{ }^{-}$para águas subterrâneas (Bole \& Bell, 1978). A colheita/remoção das plantas é fundamental não somente para prevenir possíveis aumentos no teor de $\mathrm{N}$ na solução do subsolo, evidentemente, nas águas subterrâneas, mas também, de outros nutrientes, como o P (Quin \& Forsythe, 1978; Hook, 1981). Portanto, o uso eficiente de N pelas plantas significa menores gastos com fertilizantes e menor risco de poluição de águas subterrâneas. Atingir esse objetivo é meta básica para o entendimento das transformações do $\mathrm{N}$ em lavouras irrigadas com EET (Feigin et al., 1981).

Outro fator a ser considerado, com relação ao $\mathrm{N}$, é o fato da demanda por esse nutriente e por água pelas plantas não ser paralela. Para a maioria das culturas, a demanda por $\mathrm{N}$ é maior durante o período de crescimento ativo e menor durante os estádios iniciais. Por outro lado, a demanda por água aumenta, até certo ponto, com a idade da planta (Bouwer \& Idelovitch (1987). Desse modo, o N não utilizado pelas plantas pode ser denitrificado, volatilizado ou lixiviado, consistindo-se numa fonte de N$\mathrm{NO}_{3}{ }^{-}$para o subsolo, podendo atingir águas subterrâneas.

$\mathrm{O}$ ciclo do $\mathrm{N}$-efluente em dois ecossistemas (floresta e pastagem) mediante o emprego de isótopos foi estudado por de Jordan et al. (1997). Desse modo, foi possível estimar a retenção de N-efluente pelo sistema solo-planta, utilizando-se o balanço de massa de ${ }^{15} \mathrm{~N}$. Porém, esses autores chamaram atenção ao fato de que devido ao baixo teor de ${ }^{15} \mathrm{~N}$ enriquecido no efluente, pequenas variações no ambiente seriam o suficiente para invalidar o uso de técnicas de balanço de massa; no entanto, esse problema normalmente não ocorre em ecossistemas limitantes em $\mathrm{N}$ ou em condições de maiores teores de enriquecimento isotópico. Assim, o entendimento das transformações do $\mathrm{N}$ - 
efluente mediante a disposição da água residuária no solo é um tema que ainda carece muitas informações.

A irrigação com EET, pelo fato de fornecer água e nutrientes às plantas, ao mesmo tempo, aproxima-se de uma adubação tardia. Bigeriego et al. (1979) verificaram que adubação tardia no milho tem tido particular atenção na agricultura irrigada, onde os incrementos de umidade são plausíveis, seguindo-se da aplicação de $\mathrm{N}$ na zona radicular da cultura. Assim, a aplicação tardia de fertilizantes nitrogenados tem levado a ocorrência de um dreno direto do $\mathrm{N}$-adubo para os grãos e consequentemente, menor imobilização nas partes vegetativas. Por outro lado, a quantidade de irrigação e de fertilizante nitroge nado têm influenciado diretamente os componentes de crescimento, da produção e a produtividade da cultura do milho (Araújo et al., 1999). Então, é de se esperar que o EET tenha potencialidade de uso como fonte d'água e de nutrientes ao milho, principalmente de $\mathrm{N}$.

Considerando o EET como um fertilizante nitrogenado, tanto as perdas de N$\mathrm{NO}_{3}{ }^{-}$para as águas subterrâneas como a sua denitrificação, são maléficas ao ambiente. Desse modo, práticas alternativas de fertilização (como exemplo o manejo adequado da aplicação de efluentes) podem reduzir a liberação de gases traços (como $\mathrm{NO}$ e $\mathrm{N}_{2} \mathrm{O}$ ), a perda de nutriente $\left(\mathrm{NO}_{3}{ }^{-}\right)$e ainda, manter a produtividade das culturas. Porém, essas alternativas requerem maior conhecimento a despeito do uso eficiente de nutrientes visando substituir o elevado aporte dos mesmos e pode aumentar a competitividade dos produtores (Matson et al., 1998).

As culturas potenciais para receberem efluente de esgoto, segundo Segarra et al. (1996), deveriam satisfazer todos ou a maioria dos critérios seguintes:
a) Alta absorção de N;
b) Alto consumo d'água (dado o objetivo de estudo e limitação de área);
c) Potencial de uso no processamento quando necessário;
d) Potencial de mercado nacional e internacional;
e) Retorno relativamente alto. 
Além do fator cultura, quando se trata do estabelecimento de locais para disposição de efluentes no solo, mediante irrigação de plantas, outros fatores chaves deveriam ser considerados:

a) Localização das lavouras irrigadas com despeito às vias de domínio público, residências e aqüíferos potáveis, bem como a distância entre as linhas de condução d'água potável e não potável (Bouwer \& Idelovitch, 1987);

b) Método de irrigação empregado (se aspersão, problema com aerossóis) e taxas de aplicação de fertilizantes (Bouwer \& Idelovitch, 1987);

c) Tipo de solo e topografia: o solo deve possuir drenagem livre para evitar alagamento, ser suficientemente profundo, livre de fendas, para filtrar microrganismos e ainda, a topografia deve ser favorável a irrigação (Quin, 1978);

d) Teor de matéria orgânica: quanto maior o teor de $\mathrm{C}$, maior a capacidade para imobilização microbiana de N (Jordan et al., 1997);

e) O clima no qual as plantas crescem deve ser restringido por déficit hídrico pelo menos num período do ano (Quin, 1978);

f) Composição biológica e química do efluente (Bouwer \& Idelovitch, 1987), bem como a forma química de $\mathrm{N}$ predominante na água residuária (Jordan et al., 1997);

g) Armazenamento de $\mathrm{N}$ por longo período na biomassa da vegetação, por exemplo, a incorporação de $\mathrm{N}$ na madeira, é o maior mecanismo de retenção de $\mathrm{N}$ no ecossistema (Jordan et al., 1997);

h) Importância do potencial de denitrificação (Polglase et al., 1995; Jordan et al., 1997), embora esse fato tem sido duramente criticado (Hall \& Matson, 1999);

i) Colheita periódica das plantas para ocasionar a remoção de $\mathrm{N}$ e dos demais nutrientes (Quin, 1978; Hook, 1981) e para manter a capacidade de renovação do sistema solo-planta-efluente (Jordan et al., 1997).

\subsection{Análise crítica da revisão bibliográfica}

$\mathrm{Na}$ maioria dos artigos científicos consultados, nos quais a irrigação com EET levou à ocorrência de efeitos indesejáveis no sistema solo-planta-ambiente, como por exemplo acúmulo de nutrientes, sais e metais pesados no solo, absorção de excessiva de 
nutrientes e outros elementos pelas plantas e problemas de saúde humana, tais efeitos ocorreram pelo fato de estarem associados com pelo menos um dos seguintes fatores:

a) O sistema de tratamento de esgoto recebia mais efluente que a sua capacidade e portanto, tinha sua eficiência reduzida. Desse modo, o EET obtido era de baixa qualidade.

b) Havia grande proporção de despejo de águas residuárias industriais no sistema municipal de tratamento de esgoto. Assim, mesmo havendo redução nos teores de metais pesados no processo de decantação dos sólidos suspensos e outras partículas, a concentração remanescente de metais ainda era alta.

c) A redução da condutividade hidráulica do solo estava associada à alta RAS do efluente e também, ao uso de efluentes de má qualidade, com altos teores de sólidos suspensos, os quais promoviam entupimentos dos poros da superfície do solo.

d) A não adequação da qualidade microbiológica do EET com o sistema de irrigação apropriado.

e) Não havia sincronização entre a taxa de aplicação de efluente com a demanda d'água e/ou nutrientes pelas plantas. Assim, houve acúmulo de nutrientes e migração de compostos móveis (como $\mathrm{N}-\mathrm{NO}_{3}{ }^{-}$) para o subsolo.

f) Os critérios técnicos e o monitoramento do sistema solo-planta-efluente eram deficientes.

Na grande maioria dos locais onde a irrigação com EET nutriu adequadamente as plantas e não houve dano ambiental, eram situações de solo de média à alta fertilidade natural, elevada CTC e predomínio de argilominerais do tipo 2:1 na sua fração argila (solos esmectíticos). No entanto, essas características diferem grandemente nos solos tropicais brasileiros. Cerca de $65 \%$ da superfície do Brasil apresenta cobertura ferralítica $(\mathrm{Ki}=2)$ e nesta área, a caulinita é o argilomineral dominante (Melfi \& Pedro, 1977). Devido a intensa hidrólise, a qual é um fenômeno que afeta 97\% do território nacional, mais de $85 \%$ dos solos brasileiros caracterizam-se por serem ácidos e fortemente dessaturados (Melfi \& Pedro, 1978) e com ocorrência generalizada de $\mathrm{Al}^{3+}$ no complexo de troca catiônica (Olmos \& Camargo, 1979). Com relação aos compostos ferríferos na 
fração argila dos solos brasileiros, a hematita e goethita predominam em $60 \%$ e $32 \%$ do território nacional, respectivamente (Melfi et al., 1979).

Portanto, mediante análise crítica da literatura consultada, tornou-se evidente a importância de estudos relacionados à disposição de ESET através da irrigação de culturas, notadamente no Estado de São Paulo, onde mais de $45 \mathrm{Mm}^{3}$ de efluente estão sendo anualmente lançados nas águas de superfície. Desse modo, o entendimento da dinâmica do N-efluente e do impacto da disposição de ESET no solo, bem como seus efeitos na nutrição e produtividade das culturas, necessitam ser mais investigados, notadamente, em solo com carga variável. 


\section{MATERIAL E MÉTODOS}

\subsection{Caracterização do efluente de esgoto tratado}

A Sabesp/Lins (localização aproximada: 22²1'S e 4950'W) monitorou o sistema municipal de tratamento de esgoto (Figura 1) durante o período de agosto/1997 a julho/2000, através da determinação da vazão, da condutividade elétrica específica (CE) e dos teores de fósforo total (P-total), sólidos totais (ST), sólidos dissolvidos (SD), sólidos suspensos (SS), demanda bioquímica de oxigênio (DBO) e demanda química de oxigênio (DQO).

Esta estação de tratamento de esgoto (ETE) é constituída por três lagoas anaeróbias (tratamento primário) e três lagoas facultativas (tratamento secundário), denominadas de FAC-1, FAC-2 e FAC-3 (Figura 1). O período médio de residência dos efluentes tem sido de aproximadamente cinco dias nas lagoas anaeróbias e 10 dias nas lagoas facultativas. A capacidade média de produção de ESET (efluente secundário de esgoto tratado) nesta ETE tem sido da ordem de $500 \mathrm{~m}^{3}$ hora $^{-1}$.

Para fins de caracterização do efluente utilizado nos experimentos foi efetuado uma amostragem do ESET nas lagoas de estabilização (facultativas) denominadas de FAC-1 e FAC-2, no mês de julho de 2000. Coletaram-se amostras simples em cada ponto de emissão de efluentes das lagoas de estabilização. Essas amostras foram filtradas em membrana de éster celulose com diâmetros de $45 \mathrm{~mm}$ e $90 \mathrm{~mm}$ e poros com $8 \mu \mathrm{m}, 0,45 \mu \mathrm{m}$ e $0,22 \mu \mathrm{m}$. As preservações das amostras foram efetuadas seguindo os procedimentos descritos na American Public Health Association (1992).

Várias alíquotas do efluente das duas lagoas de estabilização (FAC-1 e FAC2) foram enviadas para determinação de alcalinidade (como $\mathrm{CaCO}_{3}$ ), ânions (por Cromatografia Líquida - HPLC) e cátions (por espectrofotometria de emissão atômica 
com plasma de argônio). Determinaram-se os teores totais dos elementos mediante digestão ácida. Essas análises foram realizadas no Actalab, no Canadá.

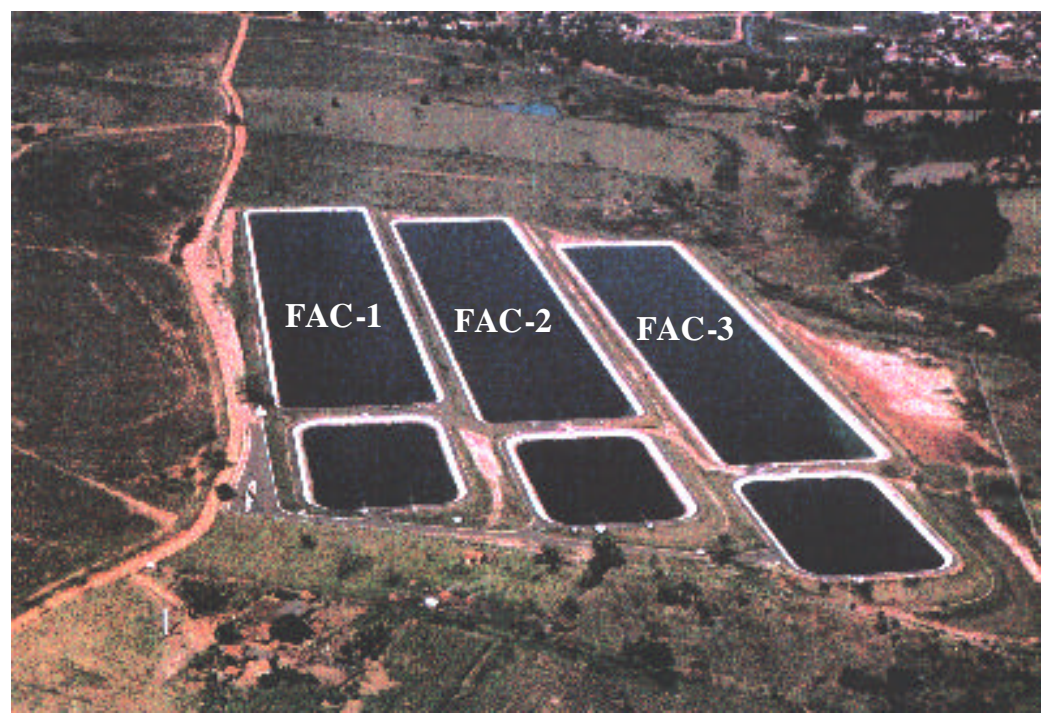

Figura 1 - Lagoas de estabilização operadas pela Sabesp na Unidade de Negócios do Baixo Tietê e Grande, município de Lins (SP). FAC-1, FAC-2 e FAC-3 correspondem às lagoas facultativas 1,2 e 3, respectivamente.

Em cada coleta de efluente para os experimentos em ambiente controlado, foram determinados os teores de matéria orgânica total (MOT), nitrogênio total (NT), nitrogênio amoniacal $\left(\mathrm{N}-\mathrm{NH}_{4}{ }^{+}\right)$, nitrogênio nítrico $\left(\mathrm{N}-\mathrm{NO}_{3}{ }^{-}\right)$e o $\mathrm{pH}$ das amostras, utilizando-se os procedimentos descritos em Kiehl (1985). Assim, determinaram-se os teores de MOT por combustão via seca $\left(550^{\circ} \mathrm{C}\right)$, após a obtenção prévia do resíduo sólido mediante secagem do efluente a $110^{\circ} \mathrm{C}$. Os teores de NT foram obtidos mediante digestão sulfúrica e leitura pelo método semi-micro-Kjeldahl. Determinaram-se os teores de $\mathrm{N}_{-} \mathrm{NH}_{4}{ }^{+}$e de $\mathrm{N}_{-} \mathrm{NO}_{3}{ }^{-}+\mathrm{N}_{-} \mathrm{NO}_{2}{ }^{-}$por destilação a vapor com $\mathrm{MgO}$ e liga de Devarda, respectivamente. Essas análises foram realizadas nos laboratórios do Departamento de Solos e Nutrição de Plantas da USP/ESALQ. Para os demais elementos/constituintes do ESET, utilizaram-se os valores obtidos pela Sabesp/Lins e pelo Actalab. 


\subsection{Experimento 1: Efeito da aplicação de efluente de esgoto tratado na disponibilidade de nitrogênio do solo}

Instalou-se um experimento, em condições controladas, simulando uma situação de irrigação por superfície, com o propósito de investigar os efeitos da aplicação de ESET na disponibilidade de N, nos teores de COT e NT e na acidez ativa do solo.

\subsubsection{Local do experimento, preparo e caracterização do substrato}

O experimento foi instalado numa estufa de circulação forçada de ar no Departamento de Solos e Nutrição de Plantas da USP/ESALQ, em janeiro de 2001.

Utilizourse amostra de terra coletadas da camada 0-20 $\mathrm{cm}$ de um Latossolo Vermelho distrófico textura média, de uma área em pousio situada próximo à ETE do município de Lins (SP).

A amostra coletada foi secada ao ar e passada por peneira de malha de $2 \mathrm{~mm}$. Antes da instalação do experimento, realizaram-se análises químicas e granulométricas da amostra de terra, seguindo os métodos propostos por Camargo et al. (1986). A amostra de terra possuía 780, 60 e $160 \mathrm{~g} \mathrm{~kg}^{-1}$ de areia, silte e argila, respectivamente e os resultados das análises químicas podem ser observados na Tabela 2.

\subsubsection{Deline amento experimental e tratamentos}

O delineamento experimental empregado foi o inteiramente casualizado, com quatro repetições, quatro tratamentos e 11 períodos de incubação sem lixiviação $(0,7$, $14,21,28,35,42,49,56,63$ e 70 dias). Os tratamentos consistiram na adição semanal de $0,100,150$ e $200 \mathrm{~mL}$ de ESET $\mathrm{kg}^{-1}$ de terra. Esses volumes de efluente não foram adicionados ao solo numa única vez, mas sim, foram parcelados em três aplicações no decorrer de cada semana.

O ESET foi distribuído de maneira uniforme sobre a superfície das amostras de terra, simulando a prática de irrigação. As unidades experimentais incubadas por maior período de tempo (70 dias) receberam 0, 1000, 1500 e $2000 \mathrm{~mL}$ de ESET kg ${ }^{-1}$ de terra, de acordo com o tratamento. Essas taxas de aplicação de ESET nas amostras de 
terra correspondem, respectivamente, as seguintes lâminas de irrigação: 0, 274, 411 e $548 \mathrm{~mm}$ de efluente. Essas lâminas correspondem a um aporte de 0, 134, 201 e $268 \mathrm{~kg}$ $\mathrm{ha}^{-1}$ de NT-efluente, cujos cálculos foram feitos a partir da concentração de NT presente no ESET (Tabela 3).

Tabela 2. Resultados de análises químicas da amostra de terra utilizada para instalação do experimento 1 .

\begin{tabular}{|c|c|c|c|c|c|c|c|c|c|c|c|}
\hline $\begin{array}{c}\mathrm{pH} \\
\left(\mathrm{CaCl}_{2}\right) \\
\end{array}$ & $\mathrm{COT}^{(1)}$ & $\mathrm{NT}^{(2)}$ & $\bar{P}$ & $\overline{\mathrm{Al}}$ & $\overline{\mathrm{Ca}}$ & $\overline{\mathrm{Mg}}$ & $\bar{K}$ & $\mathrm{H}+\mathrm{A}$ & CTC & $V^{(3)}$ & $\mathrm{m}^{(4)}$ \\
\hline & \multicolumn{2}{|c|}{$\mathrm{mg} \mathrm{kg}^{-1}$} & $\mathrm{mg} \mathrm{dm}^{-3}$ & - & - & $\mathrm{mm}$ & $\mathrm{dm}^{-3}$ & --- & ------ & ----- \% & ------ \\
\hline 4,2 & 10,6 & 1,0 & 3 & 7 & 11 & 4 & 1,7 & 22 & 38,7 & 43 & 30 \\
\hline
\end{tabular}

\subsubsection{Características do efluente utilizado}

O efluente, como anteriormente assinalado, foi coletado do sistema de lagoas de estabilização operadas pela Sabesp na Unidade de Negócios do Baixo Tietê e Grande, município de Lins (Figura 1).

Logo após a coleta do material, o mesmo foi congelado à temperatura de aproximadamente $-20^{\circ} \mathrm{C}$ (para cessar a atividade microbiana), sendo somente descongelado para sua aplicação. As características químicas do efluente utilizado podem ser observadas na Tabela 3.

\subsubsection{Condução do experimento e análise química de terra}

O experimento foi instalado no dia 02 de janeiro de 2001. Amostras de $100 \mathrm{~g}$ de terra fina seca ao ar (TFSA) foram mantidas em copos de plástico (capacidade de 250 $\mathrm{ml})$ sem furo para drenagem, à temperatura de $31^{\circ} \mathrm{C}\left( \pm 2^{\circ} \mathrm{C}\right)$ e em fração pré-determinada $( \pm 70 \%)$ da capacidade de retenção de água do solo $\left(250 \mathrm{~mL} \mathrm{~kg}^{-1}\right.$ de terra). Esta foi obtida a partir da determinação da percentagem de saturação, conforme Embrapa (1997). 
Tabela 3. Características químicas do efluente secundário de esgoto tratado oriundo da Estação de Tratamento de Esgoto de Lins, empregado no experimento 1.

\begin{tabular}{|c|c|}
\hline Constituinte & Concentração \\
\hline & $\mathrm{mg} \mathrm{L}^{-1}$ \\
\hline Sólidos totais (ST) & $578,8 \pm 60,4^{(1)}$ \\
\hline Demanda bioquímica de oxigênio (DBO) & $50,1 \pm 18,0^{(1)}$ \\
\hline Demanda química de oxigênio (DQO) & $198,1 \pm 57,7^{(1)}$ \\
\hline Matéria orgânica total & 98,6 \\
\hline N-total & 49,0 \\
\hline N-orgânico & 4,8 \\
\hline $\mathrm{N}-\left(\mathrm{NH}_{4}^{+}+\mathrm{NH}_{3}\right)$ & 42,7 \\
\hline $\mathrm{N}-\left(\mathrm{NO}_{3}^{-}+\mathrm{NO}_{2}^{-}\right)$ & 1,5 \\
\hline P-total & $6,4 \pm 1,1^{(1)}$ \\
\hline $\mathrm{Ca}$ & $8,2^{(2)}$ \\
\hline $\mathrm{Mg}$ & $1,6^{(2)}$ \\
\hline $\mathrm{K}$ & $11,0^{(2)}$ \\
\hline $\mathrm{Na}$ & $134^{(2)}$ \\
\hline $\mathrm{Cl}$ & $53^{(2)}$ \\
\hline Alcalinidade (como $\mathrm{CaCO}_{3}$ ) & $362^{(2)}$ \\
\hline $\mathrm{pH}$ & 7,8 \\
\hline Condutividade elétrica (CE), em mmho $\mathrm{cm}^{-1}$ & $0,84 \pm 0,08^{(1)}$ \\
\hline Razão de adsorção de sódio (RAS), em mmol L ${ }^{-1}$ & 15,8 \\
\hline
\end{tabular}

(1) Valores médios levantados pela Sabesp/Lins, dados de 12 amostragens no período entre agosto/1997 a julho/2000.

(2) Valores obtidos da amostra filtrada em 0,22 $\mu \mathrm{m}$. Determinações realizadas no Actalab, Canadá.

Duas vezes ao dia, durante o período de incubação, foram feitos os controles de perda de umidade das amostras por evaporação, mediante pesagem das unidades experimentais, refazendo-se, quando necessário, o peso inicial das mesmas pela adição de água deionizada e/ou efluente (conforme o tratamento).

Ao término de cada período de incubação (sete dias após a última aplicação de efluente), as unidades experimentais foram sucessivamente desmontadas e retiraram-se sub-amostras de $3 \mathrm{~g}$ de terra úmida para efetuar a extração de $\mathrm{N}$, a qual foi realizada através do uso de solução de $\mathrm{KCl} 2 \mathrm{~mol} \mathrm{~L}^{-1}$ (relação extrator:solo de 10:1). Em seguida, as sub-amostras foram agitadas por 60 minutos em agitador horizontal e na sequiência, foram filtradas com papel de filtro Whatman $n^{\circ} 1$. O extrato obtido foi congelado à 
temperatura de aproximadamente de $-20^{\circ} \mathrm{C}$. Posteriormente, determinaram-se as frações $\mathrm{N}-\mathrm{NH}_{4}{ }^{+}$e N- $\left(\mathrm{NO}_{3}{ }^{-}+\mathrm{NO}_{2}{ }^{-}\right)$por condutividade e colorimetria, respectivamente, mediante o emprego de espectroscopia de absorção molecular num sistema de análise de injeção em fluxo contínuo (FIA), conforme Ruzicka \& Hansen (1975).

As amostras dos períodos 0 e 70 dias de incubação foram secadas ao ar para posterior determinação do $\mathrm{pH}\left(\mathrm{CaCh}_{2} 0,01 \mathrm{~mol} \mathrm{~L}^{-1}\right)$, conforme proposto por Camargo et al. (1986) e análise dos teores de COT e NT, por combustão a seco, utilizando-se o aparelho LECO CN 2000.

A determinação do $\mathrm{pH}(\mathrm{CaCh})$ das amostras foi realizada nos laboratórios do Departamento de Solos e Nutrição de Plantas da USP/ESALQ. As demais análises foram realizadas no Laboratório de Biogeoquímica Ambiental da USP/CENA.

\subsubsection{Cálculo do nitrogênio mineral disponível e análises estatísticas}

A contribuição das taxas de aplicação de ESET na disponibilidade de $\mathrm{N}^{-\mathrm{NH}_{4}}{ }^{+}$ e $\mathrm{N}_{-} \mathrm{NO}_{3}{ }^{-}$nas amostras de terra foi calculada para cada período de incubação, utilizandose a eq. (1).

$$
N_{d}=N_{e}-N_{m}
$$

onde: $N_{d}=$ teor de $\mathrm{N}$-mineral disponível em solução $\mathrm{KCl} 2 \mathrm{~mol} \mathrm{~L}^{-1}\left(\mathrm{~N}_{-} \mathrm{NH}_{4}{ }^{+}+\mathrm{N}-\mathrm{NO}_{3}{ }^{-}\right)$ nas amostras de terra, em um período de tempo qualquer, sete dias após a última irrigação com ESET; $N_{e}=$ quantidade de NT-efluente acumulado (calculado a partir da concentração de NT-efluente apresentado na Tabela 3 pelo produto do volume de ESET irrigado até um determinado período de tempo); $N_{m}=$ quantidade de $\mathrm{N}$ mineralizado nas amostras de terra no tratamento testemunha, a um período de tempo qualquer.

Salienta-se que em experimentos com efluentes não é possível determinar a disponibilidade de $\mathrm{N}$ mediante o emprego de uma equação de primeira ordem, conforme preconizado pela Cetesb (1999) para determinação da fração de mineralização do $\mathrm{N}$ de biossólidos. Este fato ocorre porque o N-biossólido é aplicado ao solo numa dada ocasião, para uma determinada cultura. Assim, mediante a mineralização deste material (biossólido), o N (predominantemente orgânico) é disponibilizado no sistema solo- 
planta e essa mineralização pode ser descrita por uma equação de primeira ordem (Chae \& Tabatabai, 1986).

Já no ESET, a fração N-orgânico é muito baixa (Tabelas 1 e 3) e ainda, este resíduo líquido é adicionado ao solo constantemente, em função da demanda hídrica do meio.

Os valores de $\mathrm{pH}(\mathrm{CaCh})$, COT e NT, dos períodos 0 e 70 dias de incubação, foram submetidos à análise de variância de acordo com o modelo de experimento inteiramente casualizado. Mediante análises de regressão por polinômios ortogonais, ajustaram-se equações aos valores de $\mathrm{pH}(\mathrm{CaCb})$, COT e NT em função da quantidade de efluente adicionado semanalmente às amostras de terra e aos teores de $\mathrm{N}$ mineral $(\mathrm{N}$ $\mathrm{NH}_{4}{ }^{+}+\mathrm{N}^{-\mathrm{NO}_{3}}{ }^{-}$) em função da quantidade de NT adicionada às amostras de terra pela

disposição do ESET. Consideraram-se apenas as regressões de coeficientes de determinação significativos a 1\%. As análises estatísticas foram executadas por meio de programa de computador ESTAT, conforme método descrito em Banzatto \& Kronka (1989).

\subsection{Experimento 2: Alterações nas características químicas do solo, nutrição e produção de matéria seca do milho pela aplicação de efluente de esgoto tratado}

Com o propósito de averiguar os efe itos da irrigação com ESET, como fonte d'água e de nutrientes às plantas de milho, instalourse um experimento, em casa-devegetação onde foi avaliado os efeitos da disposição de efluente no sistema solo-planta.

\subsubsection{Local do experimento, preparo do substrato e caracterização do efluente}

O experimento foi instalado na casa de vegetação do Departamento de Solos e Nutrição de Plantas da USP/ESALQ em março de 2001. A amostra de terra utilizada era de um Latossolo Vermelho distrófico textura média, de uma área em pousio situada próximo à ETE do município de Lins (SP).

A terra coletada foi secada ao ar e passada por peneira de malha de $4 \mathrm{~mm}$. Na Tabela 4 pode ser observado os resultados de análises químicas e granulométricas do substrato utilizado para instalação do experimento. 
Tabela 4. Resultados de análises químicas e granulométricas da amostra de terra utilizada para instalação do experimento 2.

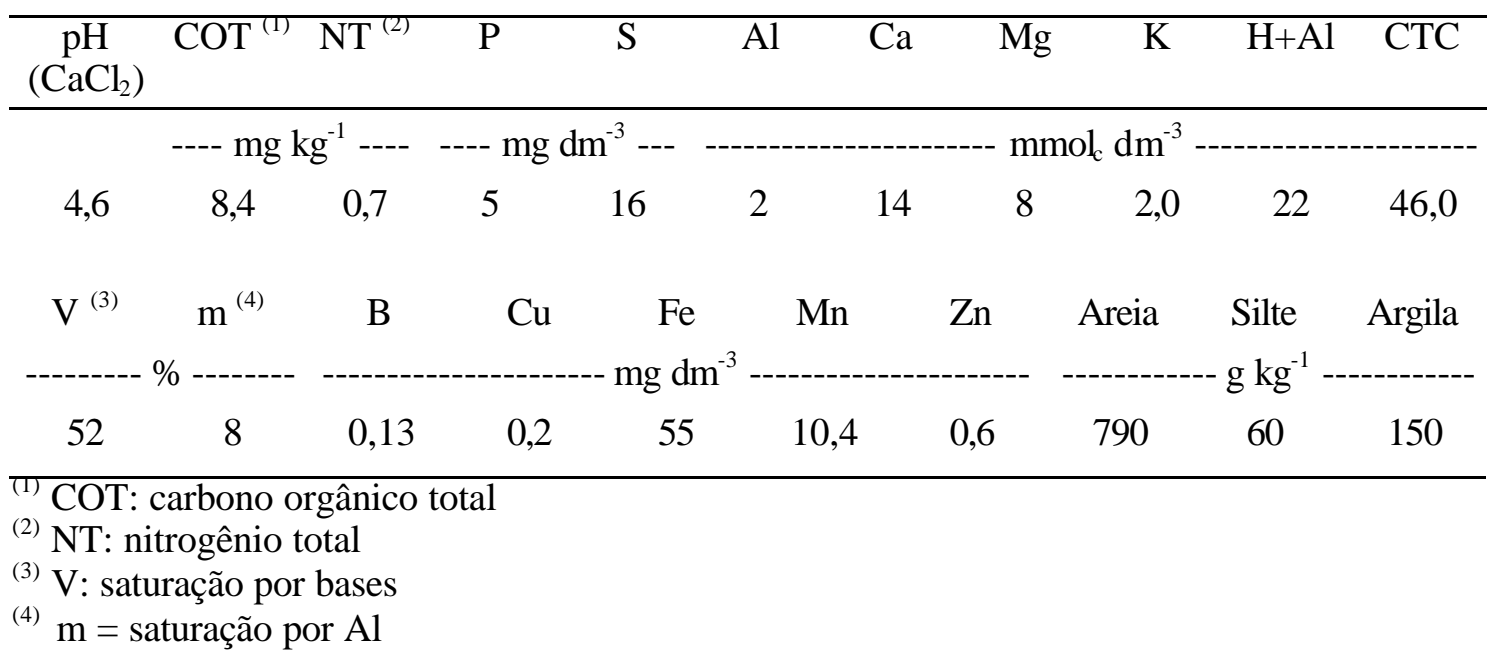

Tendo em vista os resultados mostrados na Tabela 4, foi necessária a correção da acidez do substrato, através da calagem, com o objetivo de elevar a saturação por bases a 70\% para atender a necessidade da cultura do milho (Raij et al., 1996). Assim, adicionou-se às amostras de terra o equivalente a $0,92 \mathrm{t} \mathrm{ha}^{-1}$ de calcário dolomítico, o qual apresentava teores de $\mathrm{CaO}$ e $\mathrm{MgO}$ de 30,8\% e 19,8\%, respectivamente e PRNT (Poder Relativo de Neutralização Total) de 90,1\%. A quantidade de calcário aplicada em cada unidade experimental foi corrigida, levando-se em consideração a densidade da amostra de terra $\left(1,37 \mathrm{~g} \mathrm{~cm}^{-3}\right)$. A densidade global foi determinada pelo método da proveta, segundo Embrapa (1997). Procedeu-se a homogeneização do corretivo e da terra com o uso de uma betoneira. Em seguida, as amostras de terra foram incubadas em casa de vegetação por um período de 21 dias, em condições de umidade para adequada reação do corretivo. Após esse período, a terra foi novamente secada ao ar para realização das etapas de adubação e semeadura.

Os efluentes foram coletados do sistema de lagoas de estabilização (FAC-1 e FAC-2) operadas pela Sabesp na Unidade de Negócios do Baixo Tietê e Grande, município de Lins (Figura 1). Logo após a coleta, o material foi conservado em câmara fria à temperatura de $0^{\circ} \mathrm{C}$. Para a irrigação das plantas, foi utilizada a mistura dos efluentes da FAC-1 e FAC-2, cujas características químicas podem ser observadas na 
Tabela 5. Antes da disposição dos ESET nas unidades experimentais, os mesmos eram deixados à temperatura ambiente pelo menos meia hora antes da prática de irrigação.

\subsubsection{Delineamento experimental e tratamentos}

Empregou-se o delineamento experimental de blocos completos casualizados, com cinco repetições e cinco tratamentos. Os tratamentos foram:

a) Irrigação com água deionizada e adubação mineral completa, exceto N (T1);

b) Irrigação com água deionizada e adubação mineral completa (T2);

c) Somente irrigação com efluente, sem nenhuma adição de fertilizante mineral (T3);

d) Irrigação com efluente e adubação mineral completa, exceto N (T4);

e) Irrigação com efluente e adubação mineral completa (T5).

\subsubsection{Condução do experimento}

Cada parcela consistiu de um vaso plástico com capacidade de 12,5 litros, contendo $10 \mathrm{~kg}$ de terra, previamente corrigida com calcário dolomítico. A semeadura do milho (hibrido simples Avant) foi realizada em 26 de março de 2001, colocando-se 12 sementes por vaso. A emergência das plântulas ocorreu no quinto dia após a semeadura. O desbaste foi realizado aos cinco dias após a emergência (DAE), deixandose quatro plantas por vaso.

A adubação foi conduzida conforme preconizada por Malavolta (1980). As fontes e quantidades de fertilizantes minerais adicionados às unidades experimentais podem ser observadas na Tabela 6 . Todo $\mathrm{P}$ e $1 / 3$ do $\mathrm{K}$ foram misturados às amostras mediante o uso de uma betoneira, antes da semeadura. Aplicaram-se junto a água e/ou efluente via irrigação, $1 / 3$ da fertilização nitrogenada e os micronutrientes $\mathrm{B}, \mathrm{Cu}, \mathrm{Fe}$, Mn, Mo e Zn, por ocasião da semeadura. O restante da fertilização nitrogenada e potássica foram parceladas em duas vezes (aos 20 e 40 DAE), junto à irrigação com água ou efluente. 
Tabela 5. Características químicas do efluente secundário de esgoto tratado oriundo da Estação Tratamento de Esgoto de Lins, empregado no experimento 2.

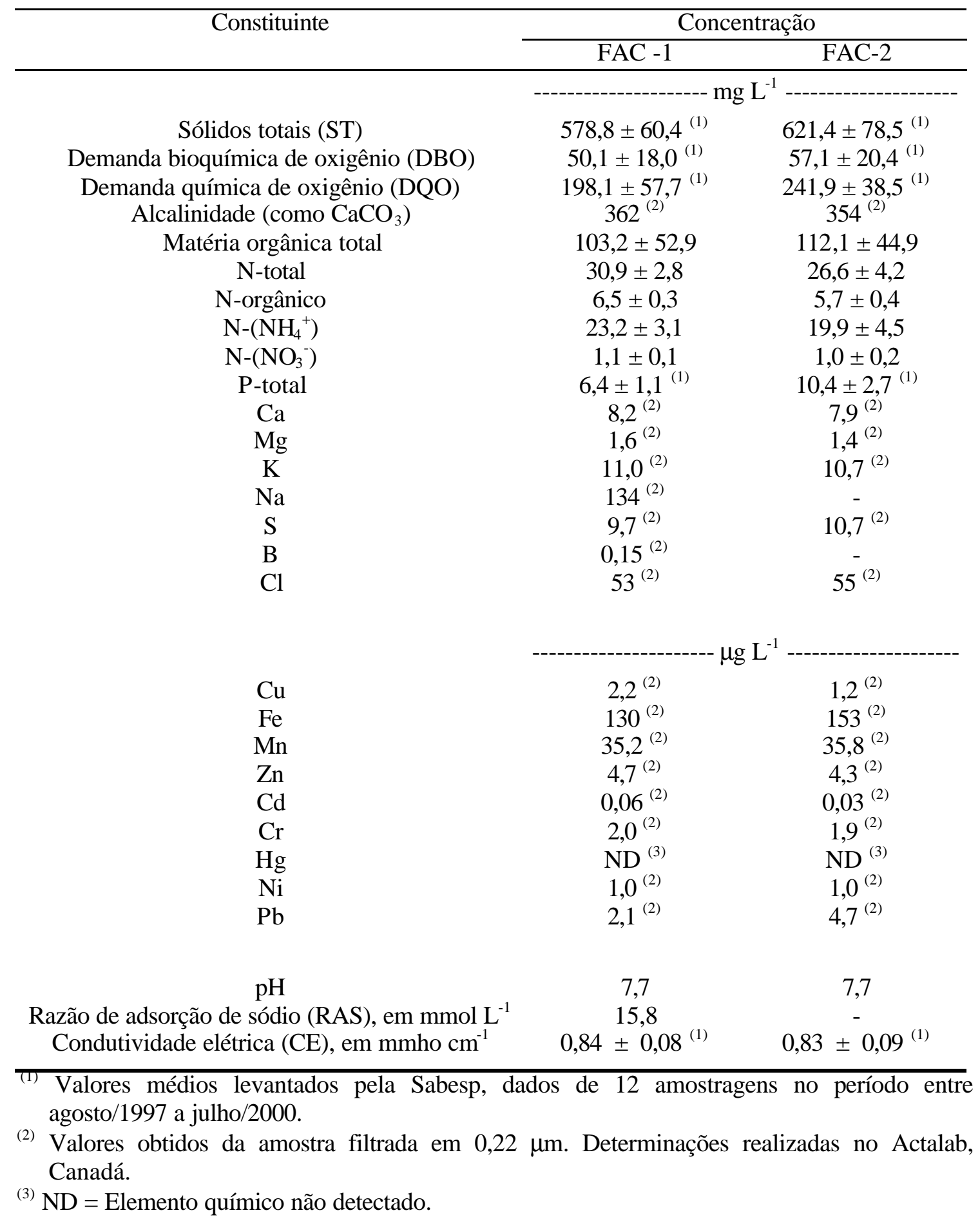


Tabela 6. Quantidades e fontes de nutrientes aplicados nas amostras de terra.

\begin{tabular}{ccc}
\hline Nutriente & Concentração & Fonte \\
\hline & $\mathrm{mg} \mathrm{kg}^{-1}$ & \\
Nitrogênio & 300 & Uréia $(45 \% \mathrm{~N})$ \\
Fósforo & 200 & Superfosfato simples $\left(18 \% \mathrm{P}_{2} \mathrm{O}_{5}\right)$ \\
Potássio & 150 & Cloreto de potássio $\left(60 \% \mathrm{~K}_{2} \mathrm{O}\right)$ \\
Boro & 0,5 & Ácido bórico $(17 \% \mathrm{~B})$ \\
Cobre & 1,5 & Sulfato de cobre pentahidratado $(25 \% \mathrm{Cu})$ \\
Ferro & 5,0 & Ferro EDTA $\left(5000 \mathrm{mg} \mathrm{kg}^{-1}\right)$ \\
Manganês & 3,0 & Cloreto de manganês tetrahidratado $(28 \% \mathrm{Mn})$ \\
Molibdênio & 0,1 & Ácido molíbdico $(48 \% \mathrm{Mo})$ \\
Zinco & 5,0 & Sulfato de zinco heptahidratado $(22 \% \mathrm{Zn})$ \\
\hline
\end{tabular}

A quantidade de umidade perdida por evapotranspiração era reposta às unidades experimentais adicionando-se, quando necessário, água e/ou efluente para refazer a umidade em $70 \%$ da capacidade de retenção de água da amostra de terra (230 $\mathrm{mL} \mathrm{kg}^{-1}$ de terra). A determinação da capacidade de retenção de água da amostra foi feita através do cálculo do poder de embebição do solo, conforme Embrapa (1997).

Os valores de temperatura do ar (máximas, mínimas e médias) da casa de vegetação, durante o decorrer do experimento, podem ser observados na Figura 2.

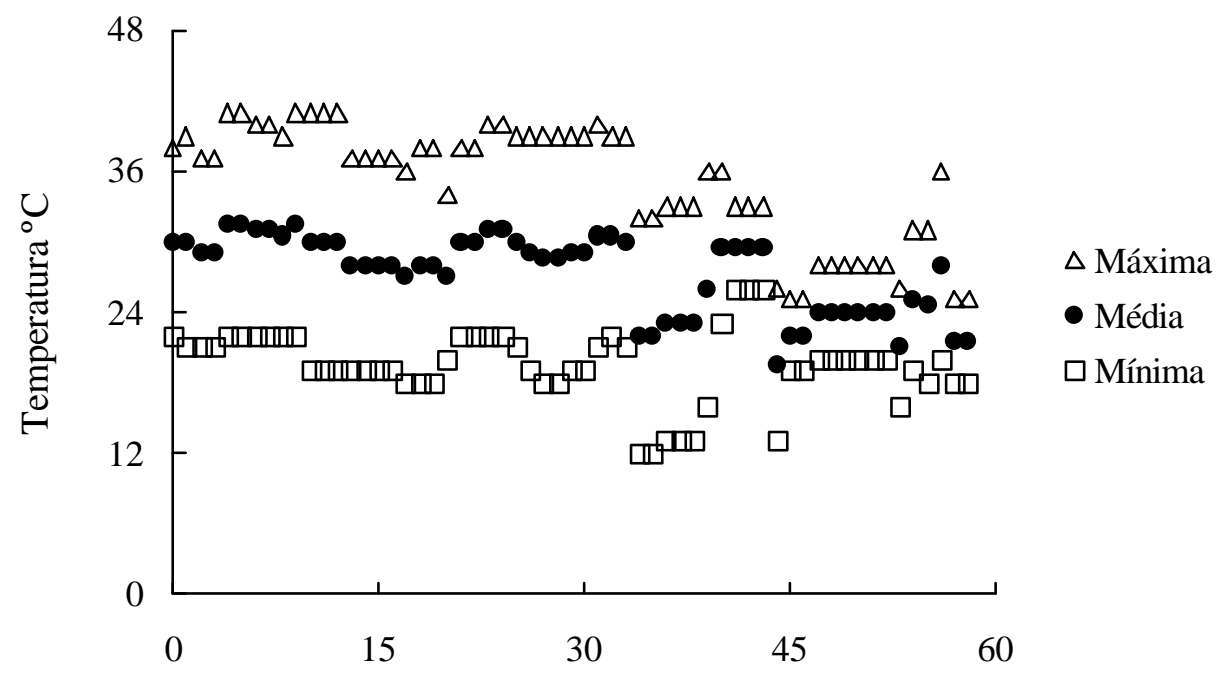

Dias após a emergência

Figura 2 - Valores das temperaturas máximas, mínimas e médias na casa-de-vegetação durante o decorrer do experimento. 


\subsubsection{Medição indireta da clorofila}

A concentração de clorofila presente nas folhas das plantas foi avaliada aos 58 DAE das plântulas, por meio de clorofilômetro, marca Minolta, Modelo SPAD-502, com o qual foram realizadas quatro leituras por unidade experimental. Somente foi avaliada a terceira folha completamente expandida de cada planta. Procuroutse correlacionar os teores de $\mathrm{N}$ da folha avaliada com os valores de leituras do clorofilômetro.

\subsubsection{Avaliação da quantidade de matéria seca}

Aos 58 DAE as plantas encontravam-se no estádio 4 (inflorescência masculina). Então, realizou-se o corte das mesmas rente ao substrato e a parte aérea foi separada em folhas e colmos. As folhas e os colmos foram lavados com água deionizada e colocados para secar em estufa com circulação forçada de ar à temperatura de $60^{\circ} \mathrm{C}$ até atingir massa constante para determinação da quantidade de matéria seca.

\subsubsection{Acúmulo de nutrientes e elementos tóxicos}

Retiraram-se sub-amostras de folhas e de colmos das amostras utilizadas para determinação da quantidade de matéria seca. Essas sub-amostras foram moídas em moinho tipo "Wiley" equipado com peneira de malha 20 mesh e foram guardadas em recipientes plásticos até realização das análises químicas.

Determinaram-se, nos laboratórios do Departamento de Solos e Nutrição de Plantas da USP/ESALQ, as concentrações de N, P, K, Ca, Mg, S, Na, B, Cu, Fe, Mn, $\mathrm{Zn}, \mathrm{Cd}, \mathrm{Cr}$ e Ni nas diferentes partes das plantas, segundo os métodos descritos em Malavolta et al. (1997). Por meio de digestão sulfúrica e leitura pelo método semimicro-Kjeldahl determinaram-se as concentrações de N. A determinação das concentrações de $\mathrm{P}, \mathrm{K}, \mathrm{Ca}, \mathrm{Mg}, \mathrm{S}, \mathrm{Na}, \mathrm{Cu}, \mathrm{Fe}, \mathrm{Mn}, \mathrm{Zn}, \mathrm{Cd}, \mathrm{Cr}$ e Ni foi feita mediante digestão nítrico-perclórica e leitura por colorimetria de metavanadato para P; turbidimetria do sulfato de bário para $\mathrm{S}$; fotometria de emissão de chama para $\mathrm{K}$ e $\mathrm{Na}$; espectrofotometria de absorção atômica para $\mathrm{Ca}, \mathrm{Mg}, \mathrm{Cu}, \mathrm{Fe}, \mathrm{Mn} \mathrm{e} \mathrm{Zn}$; e espectrofotometria de emissão atômica com plasma de argônio para $\mathrm{Cd}, \mathrm{Cr}$ e $\mathrm{Ni}$. O limite estimado de detecção do plasma encontrava-se em torno de 0,002 $\mathrm{mg} \mathrm{L}^{-1}$. Este 
valor corresponderia a uma concentração, na matéria seca, de aproximadamente $1 \mathrm{mg}$ $\mathrm{kg}^{-1}$. As concentrações de B foram determinadas por meio de digestão via seca (incineração) e colorimetria de azometina $\mathrm{H}$.

Para o cálculo do acúmulo de nutrientes e/ou metais pesados, foi empregado o produto da concentração do elemento químico pela matéria seca da parte da planta. Assim obteve-se a quantidade de nutrientes e/ou metais pesados não essenciais absorvidos pelas folhas, colmos e por toda parte aérea.

\subsubsection{Análise da terra}

Após a coleta das plantas, as amostras de terra foram secadas ao ar e passadas por peneira de $2 \mathrm{~mm}$ de malha. Determinaram-se, nos laboratórios do Departamento de Solos e Nutrição de Plantas da USP/ESALQ, os valores de $\mathrm{pH}(\mathrm{CaCh}), \mathrm{CE}$ (condutividade elétrica), acidez potencial (método direto) e os teores de $\mathrm{Ca}, \mathrm{Mg}, \mathrm{K}, \mathrm{Na}$, P, S e B, utilizando-se os métodos propostos por Camargo et al. (1986).

A determinação dos teores de COT e NT foram feitas por combustão a seco, utilizando-se o aparelho LECO CN 2000, no Laboratório de Biogeoquímica Ambiental da USP/CENA. E quanto aos metais pesados ( $\mathrm{Cd}, \mathrm{Cr}, \mathrm{Cu}, \mathrm{Fe}, \mathrm{Mn}, \mathrm{Ni}, \mathrm{Pb}$ e $\mathrm{Zn}$ ), determinaram-se, no Laboratório de Análise de Solo e Planta do Centro de Solos e Recursos Ambientais do Instituto Agronômico de Campinas, seus respectivos teores disponíveis em DTPA, conforme Abreu et al. (2001).

\subsubsection{Análises estatísticas}

Os resultados foram submetidos à análise de variância de acordo com o modelo de experimento de blocos completos casualizados. Nos casos de F significativo, foi aplicado o teste de Tukey a $1 \%$. As análises estatísticas foram executadas por meio de programa de computador ESTAT, conforme método descrito em Banzatto \& Kronka (1989). 


\section{RESULTADOS E DISCUSSÃO}

\subsection{Efeito da aplicação de efluente de esgoto tratado na disponibilidade de nitrogênio no solo}

\subsubsection{Nitrogênio total, carbono orgânico total e pH}

O N contido no ESET do presente estudo encontrava-se 90,2\% na forma mineral $\left(\mathrm{N}_{-} \mathrm{NH}_{4}{ }^{+}+\mathrm{N}^{-\mathrm{NO}_{3}}{ }^{-}\right)$, predominantemente como $\mathrm{N}-\mathrm{NH}_{4}{ }^{+}$(Tabela 3). O predomínio de $\mathrm{N}$ na forma amoniacal tem sido comum nos ESET (Bouwer \& Chaney, 1974; Feigin et al., 1991; Pescod, 1992; Al-Nakshabandi et al., 1997) e a relação N$\mathrm{NH}_{4}{ }^{+}$/NT tem sido utilizada como indicativo de disponibilidade de $\mathrm{N}$ às plantas (Feigin et al., 1984). Nas lagoas de estabilização (facultativas), há dois ambientes distintos: um redutor (maior profundidade) e outro oxidante (menor profundidade). Porém, a quantidade de $\mathrm{O}_{2}$ presente na massa de efluente não é suficiente para oxidar todo $\mathrm{N}$ $\mathrm{NH}_{4}{ }^{+}$para $\mathrm{N}-\mathrm{NO}_{3}{ }^{-}$e assim, o ESET caracteriza-se por ser um resíduo cuja forma predominante do $\mathrm{N}$ é amoniacal, pelo fato do ciclo deste nutriente não ser completo nas lagoas de estabilização. Apesar da nitrificação ser um processo muito rápido, que ocorre em questão de horas, o predomínio de $\mathrm{N}-\mathrm{NH}_{4}{ }^{+}$no efluente é vantajoso, uma vez que este cátion, juntamente com a água que se infiltra no solo, pode ser trocado e então, a sua transformação no solo pelos microrganismos pode ser retardada (Hook, 1981).

Apesar da maior parte do $\mathrm{N}$-efluente ter sido encontrado nas formas minerais prontamente disponíveis $\left(\mathrm{N}-\mathrm{NH}_{4}{ }^{+}\right.$e $\left.\mathrm{N}-\mathrm{NO}_{3}{ }^{-}\right)$, quase $10 \%$ do $\mathrm{N}$-total estava na forma de $\mathrm{N}$-orgânico (Tabela 3). Esta fração orgânica do N-efluente tem sido admitida como sendo, principalmente, algas mortas com uma rápida velocidade de decomposição, que mediante sua disposição no solo, implica na adição de $\mathrm{N}$ e C orgânicos como carboidrato 
na fração da matéria orgânica fresca (Snow et al., 1999). Certamente, a aplicação de ESET não somente proporcionou adição de $\mathrm{N}$ nas diferentes formas às unidades experimentais, mas também, de outros constituintes, inclusive de matéria orgânica.

A partir das concentrações dos componentes do ESET apresentados na Tabela 3, foi calculado, em função das taxas de aplicação do efluente $(100,150$ e $200 \mathrm{~mL}$ semana ${ }^{-1} \mathrm{~kg}^{-1}$ de terra), o provável aporte de $\mathrm{N}$ nas diferentes formas, que poderiam influenciar direta ou indiretamente a disponibilidade de N. Os resultados desses cálculos podem ser vistos na Tabela 7.

A adição semanal de efluente nas amostras de terra ocasionou um pequeno, porém significativo aumento, nos teores de NT no início e no final do período de incubação (Figura 3B). Aumentos no teores de NT pela disposição de efluente no solo também foram observados por Quin \& Woods (1978) e Friedel et al. (2000), em experimentos a campo, com diferentes tipos de solos e que receberam efluentes por vários anos.

Apesar de vários trabalhos terem relatado incremento nos teores de COT pela disposição de efluentes no solo (Quin \& Woods, 1978; Latterell et al., 1982; Friedel et al., 2000), o aporte de MOT ao sistema mediante a aplicação de ESET (Tabela 7) não alterou os teores de COT das amostras de terra (Figura 3C). Provavelmente, a quantidade de $\mathrm{C}$ consumida pelos microrganismos foi reposta pelo $\mathrm{C}$-efluente ou os microrganismos tiveram preferência por utilizar a matéria orgânica do efluente como fonte de energia. Também, há possibilidades do gradiente de incremento nos teores de COT nas amostras terem sido tão pequeno que o método empregado não foi capaz de detectar esta variação. Possivelmente, o curto período de duração do presente estudo pode também ter sido responsável por esse resultado, pois variações nos teores de COT no solo pela adição de efluente foi observado por diversos autores (Polglase et al., 1995; Falkiner \& Smith, 1997; Friedel et al., 2000) em ensaios de mais longa duração. 
Tabela 7. Taxas de aplicação do efluente secundário de esgoto tratado e provável aporte de alguns dos seus constituintes (calculados a partir da Tabela 5) nas amostras de terra, durante o decorrer do período experimental.

\begin{tabular}{|c|c|c|c|c|c|c|}
\hline \multirow{2}{*}{$\begin{array}{c}\text { Período } \\
\text { experimental }\end{array}$} & \multicolumn{6}{|c|}{ Constituintes do efluente adicionados às amostras de terra } \\
\hline & N-total & ${\mathrm{N}-\mathrm{NH}_{4}^{+}}^{+}$ & $\mathrm{N}-\mathrm{NO}_{3}$ & N-orgânico & MOT $^{(1)}$ & $\mathrm{CaCO}_{3}{ }^{(2)}$ \\
\hline \multirow[t]{2}{*}{ dias } & \multicolumn{6}{|c|}{ (-1 } \\
\hline & \multicolumn{6}{|c|}{$100 \mathrm{~mL} \mathrm{semana}^{-1} \mathrm{~kg}^{-1}$ de terra } \\
\hline 0 & 4,90 & 4,27 & 0,15 & 0,48 & 9,86 & 3,62 \\
\hline 7 & 9,80 & 8,54 & 0,30 & 0,96 & 19,72 & 7,24 \\
\hline 14 & 14,70 & 12,81 & 0,45 & 1,44 & 29,58 & 10,86 \\
\hline 21 & 19,60 & 17,08 & 0,60 & 1,92 & 39,44 & 14,48 \\
\hline 28 & 24,50 & 21,35 & 0,75 & 2,40 & 49,30 & 18,10 \\
\hline 35 & 29,40 & 25,62 & 0,90 & 2,88 & 59,16 & 21,72 \\
\hline 42 & 34,30 & 29,89 & 1,05 & 3,36 & 69,02 & 25,34 \\
\hline 49 & 39,20 & 34,16 & 1,20 & 3,84 & 78,88 & 28,96 \\
\hline 56 & 44,10 & 38,43 & 1,35 & 4,32 & 88,74 & 32,58 \\
\hline \multirow[t]{2}{*}{63} & 49,00 & 42,70 & 1,50 & 4,80 & 98,60 & 36,20 \\
\hline & \multicolumn{6}{|c|}{$150 \mathrm{~mL} \mathrm{semana}^{-1} \mathrm{~kg}^{-1}$ de terra } \\
\hline 0 & 7,35 & 6,41 & 0,23 & 0,72 & 14,79 & 5,43 \\
\hline 7 & 14,70 & 12,81 & 0,45 & 1,44 & 29,58 & 10,86 \\
\hline 14 & 22,05 & 19,22 & 0,68 & 2,16 & 44,37 & 16,29 \\
\hline 21 & 29,40 & 25,62 & 0,90 & 2,88 & 59,16 & 21,72 \\
\hline 28 & 36,75 & 32,03 & 1,13 & 3,60 & 73,95 & 27,15 \\
\hline 35 & 44,10 & 38,43 & 1,35 & 4,32 & 88,74 & 32,58 \\
\hline 42 & 51,45 & 44,84 & 1,58 & 5,04 & 103,53 & 38,01 \\
\hline 49 & 58,80 & 51,24 & 1,80 & 5,76 & 118,32 & 43,44 \\
\hline 56 & 66,15 & 57,65 & 2,03 & 6,48 & 133,11 & 48,87 \\
\hline \multirow[t]{2}{*}{63} & 73,50 & 64,05 & 2,25 & 7,20 & 147,90 & 54,30 \\
\hline & \multicolumn{6}{|c|}{$200 \mathrm{~mL} \mathrm{semana}^{-1} \mathrm{~kg}^{-1}$ de terra } \\
\hline 0 & 9,80 & 8,54 & 0,30 & 0,96 & 19,72 & 7,24 \\
\hline 7 & 19,60 & 17,08 & 0,60 & 1,92 & 39,44 & 14,48 \\
\hline 14 & 29,40 & 25,62 & 0,90 & 2,88 & 59,16 & 21,72 \\
\hline 21 & 39,20 & 34,16 & 1,20 & 3,84 & 78,88 & 28,96 \\
\hline 28 & 49,00 & 42,70 & 1,50 & 4,80 & 98,60 & 36,20 \\
\hline 35 & 58,80 & 51,24 & 1,80 & 5,76 & 118,32 & 43,44 \\
\hline 42 & 68,60 & 59,78 & 2,10 & 6,72 & 138,04 & 50,68 \\
\hline 49 & 78,40 & 68,32 & 2,40 & 7,68 & 157,76 & 57,92 \\
\hline 56 & 88,20 & 76,86 & 2,70 & 8,64 & 177,48 & 65,16 \\
\hline 63 & 98,00 & 85,40 & 3,00 & 9,60 & 197,20 & 72,40 \\
\hline
\end{tabular}

(1) MOT = matéria orgânica total

(2) $\mathrm{CaCO}_{3}=$ alcalinidade como carbonato de cálcio 


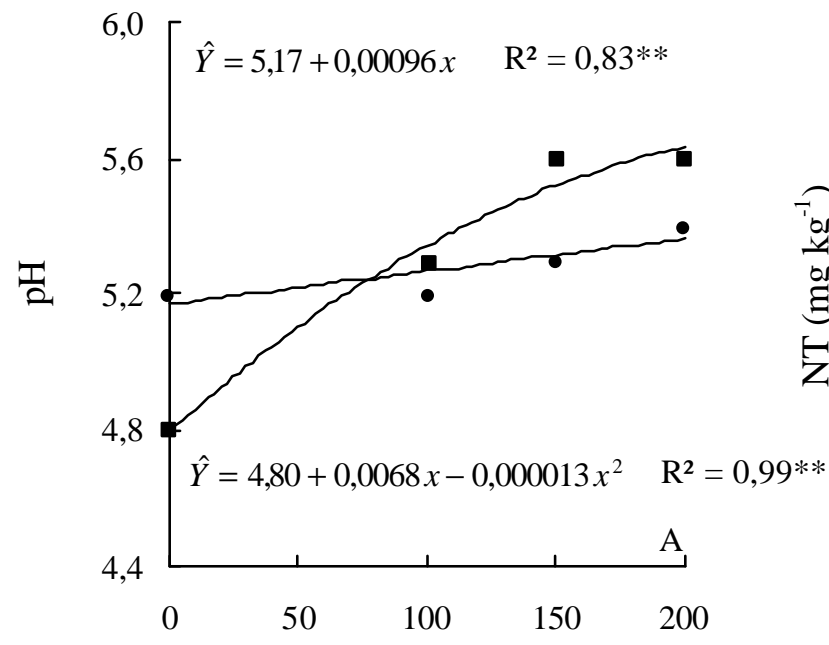

Efluente ( $\mathrm{mL}$ semana ${ }^{-1} \mathrm{~kg}^{-1}$ de terra)

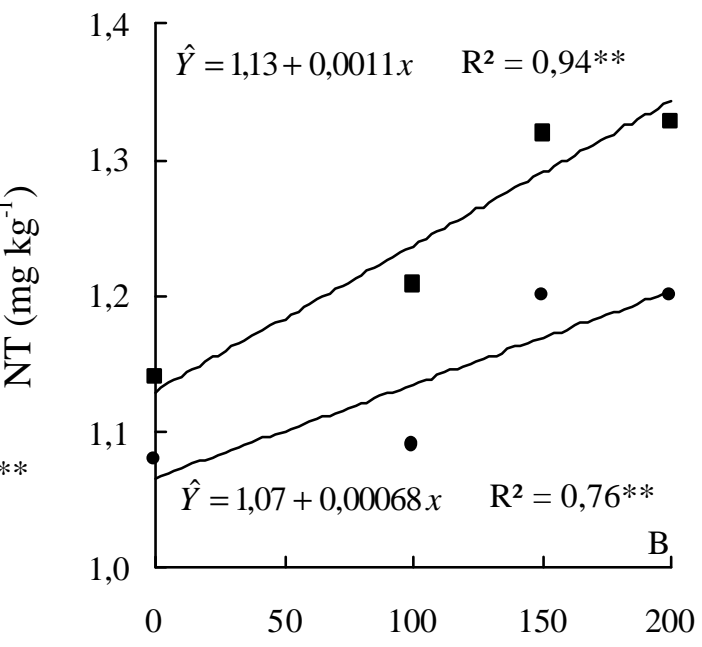

Efluente ( $\mathrm{mL} \mathrm{semana}{ }^{-1} \mathrm{~kg}^{-1}$ de terra)

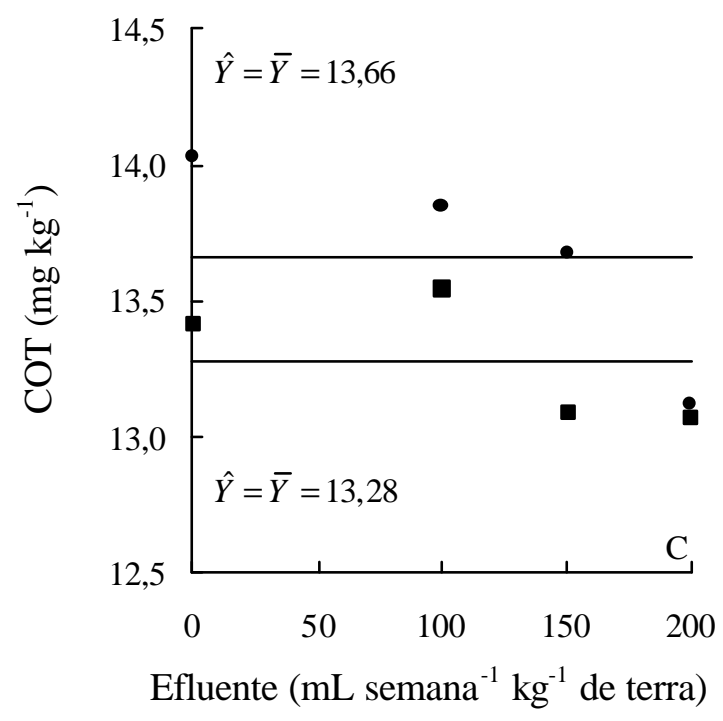

Figura 3 - Efeitos da aplicação de efluente secundário de esgoto tratado no (A) $\mathrm{pH}$ e (B) nos teores de nitrogênio total (NT) e (C) carbono orgânico total (COT) das amostras de terra, no início (• - tempo 0 de incubação) e no final (• - 70 dias de incubação. Pontos são médias de quatro repetições. ** Significativo $p<0,01$.

$\mathrm{Na}$ ausência do efluente, o teor de COT (Figura 3C) e o pH (Figura 3A) das amostras de terra foram maiores no início do experimento, quando comparados com os valores obtidos após 70 dias de incubação. Isso evidencia que as condições de 
temperatura, umidade e aeração foram adequadas à mineralização da matéria orgânica (Stanford \& Smith, 1972), produzindo $\mathrm{CO}_{2}, \mathrm{H}_{2} \mathrm{O}$, ácidos orgânicos e compostos inorgânicos (Bouwer \& Chaney, 1974). Assim, a produção de $\mathrm{CO}_{2}$ pelos microrganismos pode ter influenciado o $\mathrm{pH}$ das amostras de terra, uma vez que a dissolução do $\mathrm{CO}_{2}$ para a forma de ácido carbônico $\left(\mathrm{H}_{2} \mathrm{CO}_{3}\right)$ e a síntese e dissociação do $\mathrm{H}_{2} \mathrm{CO}_{3}$ (eq. 2) são as duas principais fontes de íons $\mathrm{H}^{+}$durante o ciclo do $\mathrm{C}$ (Bolan et al., 1991).

$$
\mathrm{CO}_{2}+2 \mathrm{H}_{2} \mathrm{O} \rightleftarrows \mathrm{H}_{3} \mathrm{O}^{+}+\mathrm{HCO}_{3}^{-}
$$

A adição de efluente às amostras de terra ocasionou ligeiro aumento no valor de $\mathrm{pH}$ no início e mais pronunciadamente, no final do período experimental, após a aplicação semanal de 1000, 1500 e $2000 \mathrm{~mL}$ de ESET $\mathrm{kg}^{-1}$ de terra, conforme o tratamento (Figura 3A). Esse fato contesta as afirmações de Bouwer \& Idelovitch (1987). Segundo esses autores, o pH da água de irrigação (incluindo o efluente) normalmente não afeta significativamente o $\mathrm{pH}$ do solo, por causa de seu poder tampão. Por outro lado, vários trabalhos também relataram aumentos de pequena magnitude (menor que uma unidade) no valor de $\mathrm{pH}$ do solo em diferentes sistemas irrigados com efluentes, tais como agrícolas (Johns \& McConchie, 1994a; AlNakshabandi et al.,1997), pastagens (Quin \& Woods, 1978) e florestas (Smith et al., 1996b; Falkiner \& Smith, 1997; Speir et al., 1999).

$\mathrm{O}$ aumento de $\mathrm{pH}$ do solo pelo uso de ESET tem sido atribuído a diversos fatores: (i) ao alto $\mathrm{pH}$ do efluente (Stewart et al., 1990); (ii) ao aumento da reserva alcalina; (iii) à adição de cátions trocáveis e de ânions oriundos do efluente (Falkiner \& Smith, 1997); (iv) ao aumento do processo de denitrificação do $\mathrm{NO}_{3}{ }^{-}$em solos irrigados com efluentes (Friedel et al., 2000), onde ocorre consumo de um mol de $\mathrm{H}^{+}$para cada mol de $\mathrm{NO}_{3}{ }^{-}$denitrificado a $\mathrm{N}_{2}$ (Bolan et al., 1991); (v) à adição de resíduos orgânicos no solo que, em função do processo de descarboxilação de ânions orgânicos e à desaminação dos aminoácidos, ocorre consumo de prótons (Yan et al., 1996). Provavelmente, todos esses fatores associados à baixa CTC da amostra de terra do experimento (Tabela 2) e ao aporte de alcalinidade pelos tratamentos com efluente (Tabela 7), contribuíram para o aumento no valor de $\mathrm{pH}$ das amostras de terra. Porém, 
estes efeitos nos solos ácidos, de baixa fertilidade natural (como o solo em questão), têm sido desprezíveis e de pouca importância prática com relação à disponibilidade de nutrientes (Speir et al., 1999).

\subsubsection{Nitrogênio mineral}

A concentração de $\mathrm{N}$-mineral $\left(\mathrm{N}-\mathrm{NH}_{4}{ }^{+}+\mathrm{N}^{-} \mathrm{NO}_{3}{ }^{-}\right)$nas amostras de terra aumentou em função da taxa e do período de aplicação do ESET (Figura 4). Esse incremento no teor $\mathrm{N}$-mineral foi devido à predominância do $\mathrm{N}$-efluente na forma mineral (Tabela 3) e à rápida mineralização da fração orgânica do N-efluente. Nos solos tratados com resíduos orgânicos, a mineralização do $\mathrm{N}$, além de ser altamente dependente da composição do resíduo e das características química e física do solo que receberá o resíduo (Chae \& Tabatabai, 1986), está diretamente relacionada à qualidade do material orgânico, bem como ao teor de N no substrato (Janssen, 1996) e à relação C/N (Mengel, 1996). Portanto, no presente estudo, admitiu-se que todo $\mathrm{N}$-orgânico adicionado às amostras de terra mediante a aplicação do ESET, foi mineralizado durante o período de tempo compreendido entre a última irrigação com efluente e a coleta das amostras para extração de N-mineral. Essa suposição foi baseada nos seguintes fatores:

a) N-orgânico e C-orgânico do efluente são admitidos como sendo algas mortas, com uma rápida velocidade de decomposiç ão (Snouw et al., 1999);

b) As condições ideais para mineralização da matéria orgânica, como umidade (Myers et al., 1982), temperatura (Artiola \& Pepper, 1992) e reabastecimento de $\mathrm{O}_{2}$ (Stanford \& Smith, 1972), foram mantidas adequadas;

c) A relação $\mathrm{C} / \mathrm{N}$ do ESET de Lins era de 1,2. A baixa relação $\mathrm{C} / \mathrm{N}$ tem sido comum nos efluentes (Bouwer \& Chaney, 1974), e isso tem indicado rápida mineralização do material orgânico (Mengel, 1996);

d) A concentração de COT não foi influenciada pelos tratamentos (Figura 3). Este fato evidenciou que o C-orgânico adicionado ao substrato via efluente era em quantidade muito pequena ou realmente o C-orgânico foi consumido em questão de poucos dias (provavelmente uma semana), ocorrendo mineralização líquida do $\mathrm{N}$. 


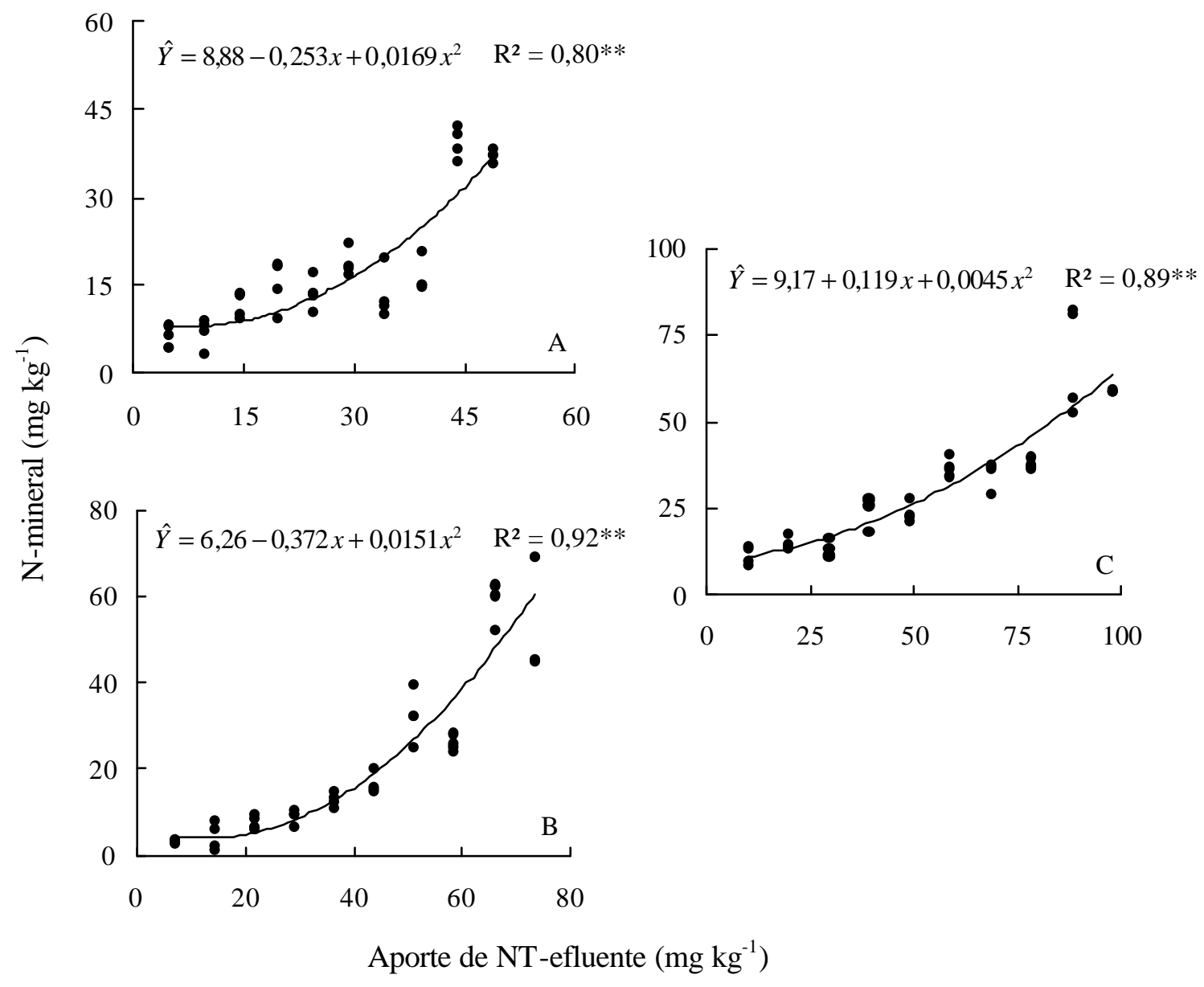

Figura 4 - Relações entre o aporte de nitrogênio total (NT) nas amostras de terra pela adição semanal de 100 (A), 150 (B) e $200 \mathrm{~mL}$ de efluente $\mathrm{kg}^{-1}$ de terra (C) e o teor de $\mathrm{N}$-mineral disponível $\left(\mathrm{N}-\mathrm{NH}_{4}{ }^{+}+\mathrm{N}^{-} \mathrm{NO}_{3}{ }^{-}\right)$, sete dias após a última aplicação de efluente. ** Significativo $p<0,01$.

Não somente a mineralização da fração orgânica do N-efluente foi rápida, mas também, a transformação do $\mathrm{N}^{-\mathrm{NH}_{4}}{ }^{+}$para $\mathrm{N}-\mathrm{NO}_{3}{ }_{3}$. O aumento no teor de $\mathrm{N}$-mineral nas amostras de terra, independentemente da taxa de aplicação do ESET, correlacionourse positivamente com o teor de $\mathrm{NO}_{3}{ }^{-}$nas amostras, mas não houve nenhuma relação significativa entre o teor de $\mathrm{NH}_{4}{ }^{+}$e o teor de $\mathrm{N}$-mineral nas amostras de terra (Tabela 8). $\mathrm{O}$ aumento no teor de $\mathrm{N}^{-} \mathrm{NO}_{3}{ }^{-}$pela disposição de efluentes ao solo tem sido comum como citado na literatura, em diferentes sistemas de manejo, cultivo, clima e solo (Hook, 1981; Bond, 1998), bem como em sistemas agrícolas (Feigin et al., 1978; Schalscha et 
al., 1979), pastagens (Quin \& Forsythe, 1978; Linden et al., 1981; Lund et al., 1981) e florestas (Hook \& Kardos, 1976; Polglase et al., 1995; Magesan et al., 1998; Smith \& Bond, 1999; Speir et al., 1999).

Tabela 8. Coeficientes de correlação entre o teor de nitrogênio mineral $\left(\mathrm{N}^{-\mathrm{NH}_{4}}{ }^{+}+\mathrm{N}-\right.$ $\mathrm{NO}_{3}{ }^{-}$) nas amostras de terra pela adição semanal de 100, 150 e $200 \mathrm{~mL}$ de efluente $\mathrm{kg}^{-1}$ de terra e os teores de $\mathrm{N}-\mathrm{NH}_{4}{ }^{+}$e $\mathrm{N}-\mathrm{NO}_{3}{ }^{-}$, sete dias após a última aplicação de efluente.

\begin{tabular}{|c|c|c|c|}
\hline \multirow[b]{2}{*}{ Parâmetro } & \multicolumn{3}{|c|}{ Taxa de aplicação semanal de efluente $\mathrm{kg}^{-1}$ de terra } \\
\hline & $100 \mathrm{~mL}$ & $150 \mathrm{~mL}$ & $200 \mathrm{~mL}$ \\
\hline $\mathrm{N}-\mathrm{NH}_{4}{ }^{+}$ & $-0,07$ & $-0,20$ & $-0,31$ \\
\hline $\mathrm{N}-\mathrm{NO}_{3}^{-}$ & $0,85 * *$ & $0,94 * *$ & $0,94 * *$ \\
\hline
\end{tabular}

** Significativo $p<0,01$

$\mathrm{O}$ predomínio de $\mathrm{N}$-mineral no efluente associado à rápida velocidade de mineralização da fração orgânica do N-efluente, tem indicado maior disponibilidade de $\mathrm{N}$ ao sistema solo-planta (Feigin et al., 1991). Por outro lado, a rápida transformação do $\mathrm{N}^{-\mathrm{NH}_{4}}{ }^{+}$a $\mathrm{N}^{-\mathrm{NO}_{3}}{ }^{-}$em condições aeróbias, como observado no presente experimento, associado à baixa retenção deste ânion no solo, tem aumentado o risco de contaminação de águas subterrânea com $\mathrm{N}-\mathrm{NO}_{3}{ }^{-}$nos locais receptores de efluentes (Schalscha et al., 1979; Bond, 1998; Smith \& Bond, 1999).

No presente trabalho não foram avaliadas perdas de N-efluente. Porém, baseando-se no possível aporte de NT pela adição de ESET (Tabela 7) e nos teores de Nmineral $\left(\mathrm{N}-\mathrm{NH}_{4}{ }^{+}+\mathrm{N}^{-\mathrm{NO}_{3}}{ }^{-}\right)$extraídos com solução $\mathrm{KCl} 2 \mathrm{~mol} \mathrm{~L} \mathrm{~L}^{-1}$ (Figura 4), calcularam-se o percentual de eficiência do N-efluente em aumentar o teor de N-mineral no solo. O percentual de NT do efluente que refletiu em incremento nos teores de N$\mathrm{NH}_{4}{ }^{+}+\mathrm{N}^{-\mathrm{NO}_{3}}{ }^{-}$nas amostras de terra, variou de 50 a $70 \%$ (média de $64 \%$ ). Isto evidenciou que cerca de 30 a $50 \%$ do N-efluente pode ter sido perdido por volatilização e/ou denitrificação.

Embora a volatilização de $\mathrm{NH}_{3}$ seja um fenômeno mais comum em solos alcalinos (o pH de equilíbrio entre $\mathrm{NH}_{4}{ }^{+}$e $\mathrm{NH}_{3}$ é de 9,5, segundo Bolan et al., 1991), há 
relatos na literatura evidenciando volatilização desse composto em solos ácidos irrigados com EET (Smith et al., 1996). A volatilização de $\mathrm{NH}_{3}$ pode ser um importante mecanismo de perda de $\mathrm{N}$ nos solos irrigados com água residuária. A concentração de $\mathrm{N}$-amoniacal no efluente, o pH da superfície do solo e a temperatura, são fatores que interferem diretamente no equilíbrio entre $\mathrm{NH}_{4}{ }^{+}$e $\mathrm{NH}_{3}$ na solução do solo e na quantidade potencial de $\mathrm{NH}_{3}$ a ser volatilizada (Smith et al., 1996a). Com base nessas considerações, provavelmente ocorreram perdas de $\mathrm{N}$ por volatilização de $\mathrm{NH}_{3}$ no presente estudo. Isso pode ser justificado pelo fato que a maior parte do Nefluente (87\%) encontrava-se como $\mathrm{N}^{-\mathrm{NH}_{4}}{ }^{+}$, o ESET era alcalino (Tabela 3) e também, devido ao fato do efluente ter sido aplicado na superfície das amostras de terra e estas foram incubadas à temperatura média de $31^{\circ} \mathrm{C}$, com circulação de ar.

A denitrificação não tem sido considerada o mecanismo mais importante de perda de $\mathrm{N}$ nos solos irrigados com efluente, pois raramente o solo irrigado adequadamente atinge o teor crítico de umidade para tornar a aeração limitante e as condições adequadas à denitrificação (Lund et al., 1981; Smith \& Bond, 1999). No entanto, outros trabalhos têm contestado as afirmações destes autores. No processo de denitrificação tem ocorrido uma estreita relação entre o teor de carbono orgânico do efluente (Bouwer \& Chaney, 1974; Schipper et al., 1996), a matéria orgânica disponível no solo (Feigin et al., 1991), o C solúvel pela decomposição de resíduos vegetais, o efeito da irrigação na diminuição do $\mathrm{O}_{2}$ no solo (Polglase et al., 1995) e o potencial de nitrificação (Polglase et al., 1995; Schipper et al., 1996). Todos esses mecanismos associados têm contribuído para que, nos solos irrigados com efluente, a taxa de denitrificação tenha aumentada de duas (Schipper et al., 1996) até mais de 50 vezes (Friedel et al., 2000). E ainda, pelo fato do ESET utilizado no presente estudo apresentar-se rico em Na (Tabela 3), certamente a aplicação do efluente ocasionou incremento nos teores deste elemento nas unidades experimentais. Então, pode ter ocorrido dispersão dos colóides nas amostras de terra, reduzindo as taxas de infiltração e aeração das mesmas, contribuindo para denitrificação do $\mathrm{NO}_{3}{ }^{-}$. Assim, todos esses mecanismos atuando conjuntamente, podem explicar a possível perda média de $36 \%$ do $\mathrm{N}$-efluente aplicado nas amostras de terra. 


\subsection{Alterações nas características químicas do solo, nutrição e produção de matéria seca do milho pela aplicação de efluente de esgoto tratado}

\subsubsection{Apresentação dos resultados}

\subsubsection{Qualidade do efluente e aporte de nutrientes pela irrigação}

Os valores de alguns constituintes importantes do ESET utilizado neste experimento (Tabela 5) foram comparados às diretrizes para interpretação da qualidade de água para irrigação (Ayers \& Westcot, 1985). Os metais pesados não se encontravam em teores limitantes à qualidade d'água para irrigação, conforme Ayers \& Westcot (1985). Todavia, o elemento mais problemático bi o Na, tanto no ESET (Tabela 9) como também na água servida à população de Lins, cujas características químicas são apresentadas na Tabela 10.

Tabela 9. Grau de restrição de uso do efluente secundário de esgoto tratado de Lins para irrigação por superfície.

\begin{tabular}{|c|c|c|}
\hline Parâmetro & ESET $^{(1)}$ & Grau de restrição de uso ${ }^{(2)}$ \\
\hline Boro, $\mathrm{mg} \mathrm{L}^{-1}$ & 0,15 & Nenhum $(<7,56)$ \\
\hline Cloro, $\mathrm{mg} \mathrm{L}^{-1}$ & 54 & Nenhum $(<142)$ \\
\hline Taxa de infiltração d'água no solo ${ }^{(3,2)}$ & - & Severo \\
\hline Razão de adsorção de sódio (RAS), mmol L ${ }^{-1}$ & 15,8 & Severo $(>9,0)$ \\
\hline 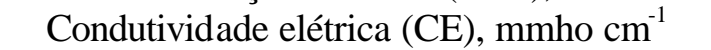 & 0,84 & Ligeiro a moderado $(0,70-3,0)$ \\
\hline
\end{tabular}

Tabela 10. Resultados de análise química da água consumida pela população de Lins/SP.

\begin{tabular}{|c|c|c|c|c|c|c|c|c|c|}
\hline $\mathrm{Ca}$ & $\overline{\mathrm{Mg}}$ & $\mathrm{Cl}$ & $\mathrm{Na}$ & $\bar{K}$ & $\mathrm{CO}_{3}{ }^{2-}$ & $\mathrm{HCO}_{3}{ }^{-}$ & $\mathrm{pH}$ & $\mathrm{CE}$ & $\overline{\mathrm{RAS}}$ \\
\hline ----- & & & $\operatorname{mg~L}$ & & . & ---------- & & 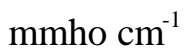 & $\mathrm{mmol} \mathrm{L}^{-1}$ \\
\hline 3,20 & 0,49 & 8,88 & 111,32 & 1,95 & 86,40 & 183,00 & 9,9 & 0,405 & 21,6 \\
\hline
\end{tabular}

A quantidade média de água deionizada aplicada aos tratamentos T1 e T2 durante o experimento foi de 29,6 e 40,0 L vaso ${ }^{-1}$, respectivamente. Já os tratamentos 
T3, T4 e T5, receberam, em média, 19,6; 34,9 e 42,0 $\mathrm{L}$ vaso ${ }^{-1}$ de ESET, respectivamente. A diferença entre a quantidade de água ou de ESET aplicado foi devido ao fato das plantas apresentarem crescimento diferenciado pelos tratamentos empregados e assim, as taxas de evapotranspiração foram diferentes. Admitindo-se as concentrações dos componentes do ESET apresentados na Tabela 5, calcularam-se o provável aporte de nutrientes e elementos tóxicos às unidades experimentais, mediante irrigação com o ESET de Lins (Tabela 11). Mesmo na maior taxa de irrigação (nas unidades experimentais que tiveram maior evapotranspiração), a quantidade de ESET aplicado adicionou menos da metade da dose de $\mathrm{N}$ preconizada para experimentos em vasos (Malavolta, 1980). Também, a disposição do efluente adicionou 4,67 vezes mais Na do que N (Tabela 11).

\subsubsection{Efeitos no solo}

Nos tratamentos irrigados com água ( $\mathrm{T} 1$ e $\mathrm{T} 2$ ), independentemente se receberam ou não fertilização nitrogenada mineral, a acidificação das amostras de terra foi mais intensa e com isso, os teores de $\mathrm{Al} \mathrm{e} \mathrm{H}+\mathrm{Al}$ aumentaram, notadamente no tratamento T2 (Tabela 12), a saturação por $\mathrm{Al}(\mathrm{m})$ foi mais elevada e a saturação por bases (V) e a $\mathrm{CTC}_{\mathrm{e}}$ diminuíram (Tabela 13). Todavia, em situações semelhantes de fertilização, as unidades experimentais irrigadas com efluente (T4 e T5) apresentaram pH mais elevado e menor acidez potencial e trocável, notadamente nas amostras não fertilizadas com $\mathrm{N}$ mineral (Tabela 12) e também, maior e menor $\mathrm{V}$ e $\mathrm{m}$, respectivamente (Tabela 13).

Os tratamentos não exerceram nenhuma influência nos teores de COT, NT (Tabela 12), B, Cd, Cr, Ni e Pb (Tabela 13). A disposição de ESET não alterou os teores de P, S, K (Tabela 12), Cu e Zn (Tabela 13) nas amostras de terra fertilizadas. Porém, mesmo recebendo irrigação com efluente, os tratamentos que não receberam adubação mineral (T3 e T4) tiveram menores teores desses nutrientes e de $\mathrm{Ca}$ e $\mathrm{Al}$ (Tabela 12) e ainda, menor $\mathrm{CTC}_{\mathrm{e}}$ e CTC (Tabela 13). Também, as amostras de terra do tratamento T3 apresentaram pH mais elevado (Tabela 12) e menor m (Tabela 13) que as amostras de terra dos tratamentos $\mathrm{T} 1 \mathrm{e}$ T2. 
O tratamento $\mathrm{T} 1$ foi o que apresentou maior teor de $\mathrm{K}$ disponível (Tabela 12), apesar de ter havido maior aporte desse nutriente nas amostras fertilizadas com $\mathrm{K}$ e irrigadas com efluente (Tabela 11).

Tabela 11. Provável aporte de matéria orgânica total, nutrientes e elementos tóxicos, adicionados às unidades experimentais (calculados a partir da Tabela 5) pela irrigação das plantas de milho com efluente secundário de esgoto tratado (ESET).

\begin{tabular}{cccc}
\hline & & & Tratamento $^{(1)}$ \\
\cline { 2 - 4 } Nutriente & $\mathrm{T}^{(2)}$ & $\mathrm{T}^{(3)}$ & $\mathrm{T}^{(4)}$ \\
\cline { 2 - 4 } Matéria orgânica total & 115,2 & $\mathrm{mg} \mathrm{kg}^{-1}$ & \\
N-total & 56,5 & 204,7 & 246,6 \\
P-total & 16,5 & 100,4 & 120,9 \\
$\mathrm{~K}$ & 21,3 & 29,3 & 35,3 \\
$\mathrm{Na}$ & 263,3 & 37,9 & 45,6 \\
$\mathrm{Ca}$ & 15,8 & 467,8 & 563,5 \\
$\mathrm{Mg}$ & 2,9 & 28,1 & 33,8 \\
$\mathrm{~S}$ & 20,0 & 5,2 & 6,3 \\
$\mathrm{Cl}$ & 106,1 & 35,6 & 42,9 \\
$\mathrm{~B}$ & 0,295 & 188,5 & 227,1 \\
$\mathrm{Fe}$ & 0,278 & 0,524 & 0,631 \\
$\mathrm{Mn}$ & 0,070 & 0,494 & 0,595 \\
$\mathrm{Cd}$ & 0,0001 & 0,124 & 0,149 \\
$\mathrm{Cr}$ & 0,0038 & 0,0002 & 0,0002 \\
$\mathrm{Cu}$ & 0,0033 & 0,0068 & 0,0082 \\
$\mathrm{Ni}$ & 0,0020 & 0,0059 & 0,0071 \\
$\mathrm{~Pb}$ & 0,0067 & 0,0035 & 0,0042 \\
$\mathrm{Zn}$ & 0,0088 & 0,0119 & 0,0143 \\
& & 0,0157 & 0,0189
\end{tabular}

(1) Foram aplicados 19,6; 34,9 e 42,0 L vaso ${ }^{-1}$ de ESET para os tratamentos T3, T4 e T5, respectivamente;

(2) T3 = somente irrigação com efluente, sem nenhuma adição de fertilizante mineral;

(3) T4 = irrigação com efluente e adubação mineral completa, exceto N;

(4) T5 = irrigação com efluente e adubação mineral completa.

A fertilização mineral ocasionou diminuição no teor de $\mathrm{Mg}$ trocável, independentemente da água de irrigação e aumentou a CE (Tabela 12). Este aumento na CE foi mais evidente nas unidades experimentais irrigadas com ESET. Desse modo, 
quanto mais fertilizantes e irrigação com ESET foram aplicados, maior foi a CE das unidades experimentais.

Tabela 12. Efeitos de fontes d'água para irrigação (efluente e água deionizada) e adubação no pH, condutividade elétrica (CE) e nos teores de $\mathrm{H}+\mathrm{Al}, \mathrm{Al}$, $\mathrm{Na}$, carbono orgânico total (COT), nitrogênio total (NT) e demais macronutrientes no solo, após o corte das plantas de milho.

\begin{tabular}{|c|c|c|c|c|c|c|}
\hline Tratamento & $\mathrm{pH}\left(\mathrm{CaCl}_{2}\right)$ & $\mathrm{CE}$ & COT & NT & $\mathrm{P}$ & $\mathrm{S}$ \\
\hline & & $\mathrm{mmho} \mathrm{cm}^{-1}$ & \multicolumn{2}{|c|}{-- $\mathrm{mg} \mathrm{kg}^{-1}$} & \multicolumn{2}{|c|}{-- $\mathrm{mg} \mathrm{dm}^{-3}$} \\
\hline $\mathrm{T} 1{ }^{(1)}$ & $4,8 \mathrm{bc} \mathrm{c}^{(7)}$ & $0,219 \mathrm{bc}$ & $8,4 \mathrm{a}$ & $0,65 \mathrm{a}$ & $70,8 \mathrm{a}$ & $106,6 \mathrm{a}$ \\
\hline $\mathrm{T} 2^{(2)}$ & $4,5 \mathrm{c}$ & $0,290 \mathrm{ab}$ & $9,2 \mathrm{a}$ & $0,73 \mathrm{a}$ & $68,4 \mathrm{a}$ & $121,0 \mathrm{a}$ \\
\hline $\mathrm{T} 3^{(3)}$ & $5,2 \mathrm{a}$ & $0,152 \mathrm{c}$ & $8,7 \mathrm{a}$ & $0,72 \mathrm{a}$ & $6,2 \mathrm{~b}$ & $21,6 \mathrm{~b}$ \\
\hline $\mathrm{T} 4{ }^{(4)}$ & $5,4 \mathrm{a}$ & $0,340 \mathrm{a}$ & $9,4 \mathrm{a}$ & $0,76 \mathrm{a}$ & $86,2 \mathrm{a}$ & $128,4 \mathrm{a}$ \\
\hline $\mathrm{T} 5^{(5)}$ & $5,0 \mathrm{ab}$ & $0,397 \mathrm{a}$ & $9,6 \mathrm{a}$ & $0,81 \mathrm{a}$ & $84,6 \mathrm{a}$ & $136,2 \mathrm{a}$ \\
\hline \multirow[t]{3}{*}{ C.V. $(\%)^{(6)}$} & 4,4 & 22,1 & 12,2 & 9,8 & 19,4 & 29,2 \\
\hline & $\mathrm{H}+\mathrm{Al}$ & Al & $\mathrm{Ca}$ & $\mathrm{Mg}$ & K & $\mathrm{Na}$ \\
\hline & & & & & & \\
\hline $\mathrm{T} 1$ & $17,0 \mathrm{~b}$ & $1,6 \mathrm{ab}$ & $18,2 \mathrm{~b}$ & $1,4 \mathrm{~b}$ & $0,7 \mathrm{a}$ & $0,7 \mathrm{c}$ \\
\hline $\mathrm{T} 2$ & $22,8 \mathrm{a}$ & $2,2 \mathrm{a}$ & $21,2 \mathrm{~b}$ & $2,0 \mathrm{~b}$ & $0,6 \mathrm{ab}$ & $0,8 \mathrm{c}$ \\
\hline $\mathrm{T} 3$ & $11,6 \mathrm{c}$ & $0,0 \mathrm{c}$ & $9,6 \mathrm{c}$ & $5,2 \mathrm{a}$ & $0,4 \mathrm{c}$ & $7,7 \mathrm{~b}$ \\
\hline $\mathrm{T} 4$ & $10,2 \mathrm{c}$ & $0,0 \mathrm{c}$ & $21,4 \mathrm{~b}$ & $2,0 \mathrm{~b}$ & $0,5 \mathrm{bc}$ & $9,5 \mathrm{ab}$ \\
\hline T5 & $14,6 \mathrm{bc}$ & $0,8 \mathrm{bc}$ & $25,8 \mathrm{a}$ & $1,6 \mathrm{~b}$ & $0,6 \mathrm{ab}$ & $10,8 \mathrm{a}$ \\
\hline C.V. (\%) & 18,0 & 52,7 & 10,0 & 32,8 & 10,1 & 17,4 \\
\hline \multicolumn{7}{|c|}{$\begin{array}{l}\text { (1) T1 =irrigação com água deionizada e adubação mineral completa, exceto N; } \\
\text { (2) T2 = irrigação com água deionizada e adubação mineral completa; } \\
\text { (3) } \mathrm{T} 3 \text { = somente irrigaçã̃o com efluente, sem nenhuma adição de fertilizante mineral; } \\
\text { (4) T4 = irrigação com efluente e adubação mineral completa, exceto N; } \\
\text { (5) T5 = irrigação com efluente e adubação mineral completa; } \\
\text { (6) C.V. = coeficiente de variação }\end{array}$} \\
\hline
\end{tabular}

Houve aumento no teor de $\mathrm{Na}$ (Tabela 12), no PST, na V e na $\mathrm{CTC}_{\mathrm{e}}$ (Tabela 13) mediante a disposição de efluente. Tais efeitos, com exceção do PST, foram mais evidentes nas unidades experimentais que receberam maiores taxas de irrigação com ESET. A CTC, assim como a CE, aumentou mediante a fertilização mineral e esse aumento foi incrementado ainda mais nas unidades experimentais que receberam maior quantidade de irrigação com efluente (Tabela 13). 
Tabela 13. Efeitos de fontes d'água para irrigação (efluente e água deionizada) e adubação na capacidade de troca catiônica (CTC) e na CTC efetiva $\left(\mathrm{CTC}_{\mathrm{e}}\right)$, saturação por bases (V) e por alumínio (m), percentual de sódio trocável (PST) e nos teores de micronutrientes e elementos tóxicos das amostras de terra.

\begin{tabular}{|c|c|c|c|c|c|c|c|}
\hline Tratamento & CTC & $\mathrm{CTC}_{\mathrm{e}}$ & $\mathrm{V}$ & $\mathrm{m}$ & PST & $\mathrm{B}$ & $\mathrm{Cu}$ \\
\hline & \multicolumn{2}{|c|}{----- $\mathrm{mmol}_{\mathrm{c}} \mathrm{dm}^{-3}$----- } & \multicolumn{3}{|c|}{------------------ $\%$----------------- } & \multicolumn{2}{|c|}{---- $\mathrm{mg} \mathrm{dm}^{-3}$} \\
\hline $\mathrm{T} 1{ }^{(1)}$ & $38,0 \mathrm{~cd}^{(7)}$ & $22,6 \mathrm{c}$ & $55,2 \mathrm{c}$ & $7,1 \mathrm{a}$ & $1,8 \mathrm{~b}$ & $0,20 \mathrm{a}$ & $1,2 \mathrm{a}$ \\
\hline $\mathrm{T} 2^{(2)}$ & $49,4 \mathrm{ab}$ & $26,8 \mathrm{c}$ & $51,7 \mathrm{c}$ & $8,2 \mathrm{a}$ & $1,7 \mathrm{~b}$ & $0,27 \mathrm{a}$ & $1,1 \mathrm{a}$ \\
\hline $\mathrm{T} 3^{(3)}$ & $34,6 \mathrm{~d}$ & $22,9 \mathrm{c}$ & $66,7 \mathrm{~b}$ & $0,0 \mathrm{~b}$ & $22,5 \mathrm{a}$ & $0,16 \mathrm{a}$ & $0,2 \mathrm{~b}$ \\
\hline $\mathrm{T} 4^{(4)}$ & $43,6 \mathrm{bc}$ & $33,4 \mathrm{~b}$ & $76,6 \mathrm{a}$ & $0,0 \mathrm{~b}$ & $21,7 \mathrm{a}$ & $0,27 \mathrm{a}$ & $1,0 \mathrm{a}$ \\
\hline $\mathrm{T} 5^{(5)}$ & $53,4 \mathrm{a}$ & 39,6 a & $73,1 \mathrm{ab}$ & $2,0 \mathrm{~b}$ & $20,3 \mathrm{a}$ & $0,30 \mathrm{a}$ & $1,1 \mathrm{a}$ \\
\hline \multirow[t]{2}{*}{ C.V. $(\%)^{(6)}$} & 8,3 & 8,9 & 6,7 & 41,5 & 15,5 & 42,2 & 15,3 \\
\hline & $\mathrm{Fe}$ & Mn & $\mathrm{Zn}$ & $\mathrm{Cd}$ & $\mathrm{Cr}$ & $\mathrm{Ni}$ & $\mathrm{Pb}$ \\
\hline T1 & $141,5 \mathrm{ab}$ & $4,1 \mathrm{bc}$ & $2,3 \mathrm{a}$ & $0,047 \mathrm{a}$ & $0,041 \mathrm{a}$ & $0,093 \mathrm{a}$ & $0,689 \mathrm{a}$ \\
\hline $\mathrm{T} 2$ & $167,6 \mathrm{a}$ & $6,4 \mathrm{a}$ & $2,8 \mathrm{a}$ & $0,045 \mathrm{a}$ & $0,042 \mathrm{a}$ & $0,096 \mathrm{a}$ & $0,710 \mathrm{a}$ \\
\hline $\mathrm{T} 3$ & $96,0 \mathrm{c}$ & $3,4 \mathrm{c}$ & $0,7 \mathrm{~b}$ & $0,037 \mathrm{a}$ & $0,038 \mathrm{a}$ & $0,071 \mathrm{a}$ & $0,699 a$ \\
\hline T4 & $95,0 \mathrm{c}$ & $3,5 \mathrm{c}$ & $2,6 \mathrm{a}$ & $0,041 \mathrm{a}$ & $0,041 \mathrm{a}$ & $0,082 \mathrm{a}$ & $0,689 \mathrm{a}$ \\
\hline T5 & $118,4 \mathrm{bc}$ & $5,4 a b$ & $2,4 \mathrm{a}$ & $0,044 \mathrm{a}$ & $0,041 \mathrm{a}$ & $0,062 \mathrm{a}$ & $0,710 \mathrm{a}$ \\
\hline C.V. (\%) & 14,8 & 16,5 & 14,7 & 23,7 & 31,5 & 34,6 & 15,1 \\
\hline \multicolumn{8}{|c|}{$\begin{array}{l}\text { (1) T1 = irrigação com água deionizada e adubação mineral completa, exceto N; } \\
\text { (2) T2 = irrigação com água deionizada e adubação mineral completa; } \\
\text { (3) T3 = somente irrigação com efluente, sem nenhuma adição de fertilizante mineral; } \\
\text { (4) } \mathrm{T} 4 \text { = irrigação com efluente e adubação mineral completa, exceto N; } \\
\text { (5) T5 = irrigação com efluente e adubação mineral completa; } \\
\text { (6) } \mathrm{C} \text {; V. = coeficiente de variação }\end{array}$} \\
\hline
\end{tabular}

A força iônica (I) da solução do solo é função da concentração e valência dos íons na solução do solo e tem tido alta correlação com a CE do solo, inclusive em solos com carga variável (Griffin \& Jurinak, 1973; Alva et al., 1991). A I pode ser obtida a partir da CE, conforme descrito na eq. (3) (Equação de Debye-Hückel, válida somente para $I<0,02 \mathrm{~mol} \mathrm{~L}^{-1}$ ).

$$
\log I=1,159+1,099 \log C E
$$


Desse modo, o aumento na CE das amostras de solo pela fertilização mineral e/ou irrigação com ESET, notadamente no tratamento T5, também ocasionou incremento na $I$ (Tabela 14).

Tabela 14. Efeitos de fontes d'água para irrigação (efluente e água deionizada) e adubação mineral na força iônica (I) da solução do solo, calculada a partir da condutividade elétrica $(\log I=1,159+1,099 \log C E)$.

\begin{tabular}{|c|c|c|c|c|c|}
\hline \multicolumn{5}{|c|}{ Tratamentos } & \multirow{2}{*}{$\begin{array}{l}\text { Coeficiente de } \\
\text { variação }\end{array}$} \\
\hline $\mathrm{T} 1^{(1)}$ & $\mathrm{T} 2^{(2)}$ & $\mathrm{T} 3^{(3)}$ & $\mathrm{T} 4^{(4)}$ & $\mathrm{T} 5^{(5)}$ & \\
\hline - & 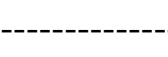 & $-\mathrm{mol} \mathrm{L}^{-1}$ & $\cdots$ & - & $\%$ \\
\hline $0,0027 b c^{(6)}$ & $0,0037 \mathrm{ab}$ & $0,0018 \mathrm{c}$ & $0,0044 \mathrm{ab}$ & $0,0052 \mathrm{a}$ & 24,6 \\
\hline
\end{tabular}

(1) T1 =irrigação com água deionizada e adubação mineral completa, exceto N;

(2) T2 = irrigação com água deionizada e adubação mineral completa;

(3) T3 = somente irrigação com efluente, sem nenhuma adição de fertilizante mineral;

(4) T4 = irrigação com efluente e adubação mineral completa, exceto N;

(5) T5 = irrigação com efluente e adubação mineral completa;

${ }^{(6)}$ Letras iguais nas colunas não diferem estatisticamente pelo teste de Tukey $(p<0,01)$.

Nas amostras fertilizadas adequadamente e irrigadas com maior quantidade de ESET (T5), houve aumento no teor de Ca (Tabela 12), na $\mathrm{CTC}_{\mathrm{e}}$ e CTC (Tabela 13). Nos tratamentos que receberam maiores taxas de aplicação de efluente (T4 e T5), que a velocidade de infiltração começou a diminuir (visualmente) aos 17 DAE. A partir desta data, o ESET infiltrava-se cada vez mais lentamente nas amostras de terra.

Menores teores de Fe e Mn foram observados nos tratamentos irrigados com efluente e que não receberam adubação nitrogenada ou nenhuma adubação mineral (Tabela 13). No entanto, maiores teores desses nutrientes foram observados nas unidades experimentais irrigadas com água e fertilizadas adequadamente (Tabela 13).

\subsubsection{Efeitos nas plantas}

$\mathrm{O}$ tratamento $\mathrm{T} 5$, apresentou, inicialmente, plantas mais vigorosas e isso contribuiu para que as plantas desse tratamento tivessem maior demanda por irrigação. Consequentemente elas cresceram mais (Figura 5) e tiveram maior evapotranspiração, 
demandando mais irrigação. Assim, as plantas que mais cresceram foram as que mais receberam os nutrientes contidos no ESET (Tabela 11).

As plantas de milho dos tratamentos T2 e T5 apresentaram desenvolvimento normal durante o experimento. Porém, aos 50 DAE surgiram alguns sintomas de toxicidade de $\mathrm{Na}$ nas plantas do tratamento $\mathrm{T} 5$, tais como queima das pontas e das margens das folhas (Figura 5).

Aos 11 DAE as plantas do tratamento T3 mostravam-se raquíticas, com coloração arroxeada próximo das margens das folhas mais velhas e também nos colmos, cujos sintomas são típicos de deficiência de P na cultura do milho. Aos 25 DAE as mesmas plantas apresentaram amarelecimento da ponta para o meio das folhas mais velhas, cujos sintomas são típicos de carência de $\mathrm{N}$.

Os teores de $\mathrm{Cd}, \mathrm{Cr}$ e Ni no extrato vegetal encontravam-se abaixo do limite de detecção $\left(0,002 \mathrm{mg} \mathrm{L}^{-1}\right.$, este valor corresponderia a uma concentração, na matéria seca, de aproximadamente $1 \mathrm{mg} \mathrm{kg}^{-1}$ ).

As plantas do tratamento T3, se comparadas às demais, apresentaram maior acúmulo de Na pelas folhas (Tabela 16). Por outro lado, tiveram menor conteúdo de $\mathrm{P}$, K, Ca (Tabela 15) e B (Tabela 16) pelas folhas, colmo e toda parte aérea, S (Tabela 15), Mn e Zn pelos colmos e toda parte aérea (Tabela 16). Já o conteúdo de $\mathrm{N}, \mathrm{Mg}, \mathrm{S}$ (Tabela 15) e metais pesados micronutrientes (Tabela 16) pelas folhas, $\mathrm{N}, \mathrm{Mg}$ (Tabela 15), $\mathrm{Cu}$ e Fe (Tabela 16) pelos colmos e por toda parte aérea, foram semelhantes, tanto nas plantas do tratamento $\mathrm{T} 1$ quanto nas do tratamento $\mathrm{T} 3$.

Comparando-se os tratamentos que receberam ESET (T3, T4 e T5), as plantas que foram fertilizadas adequadamente tiveram maior acúmulo de macronutrientes e de micronutrientes pelas folhas, colmos e por toda parte aérea (Tabelas 15 e 16). Com relação aos tratamentos que receberam fertilização mineral e irrigação com efluente (T4 e T5), quando as plantas não receberam adubação nitrogenada mineral, houve redução no conteúdo de macronutrientes (Tabela 15), Na, B, Cu, Mn e Zn (Tabela 16) pelas folhas, de N, P, Ca, Mg, S (Tabela 15), Na, B, Cu, Fe e Zn (Tabela 16) pelos colmos e de todos os nutrientes por toda parte aérea (Tabelas 15 e 16). Porém, foram iguais o acúmulo de Fe (Tabela 16) pelas folhas, K (Tabela 15) e Mn (Tabela 15) pelos colmos. 

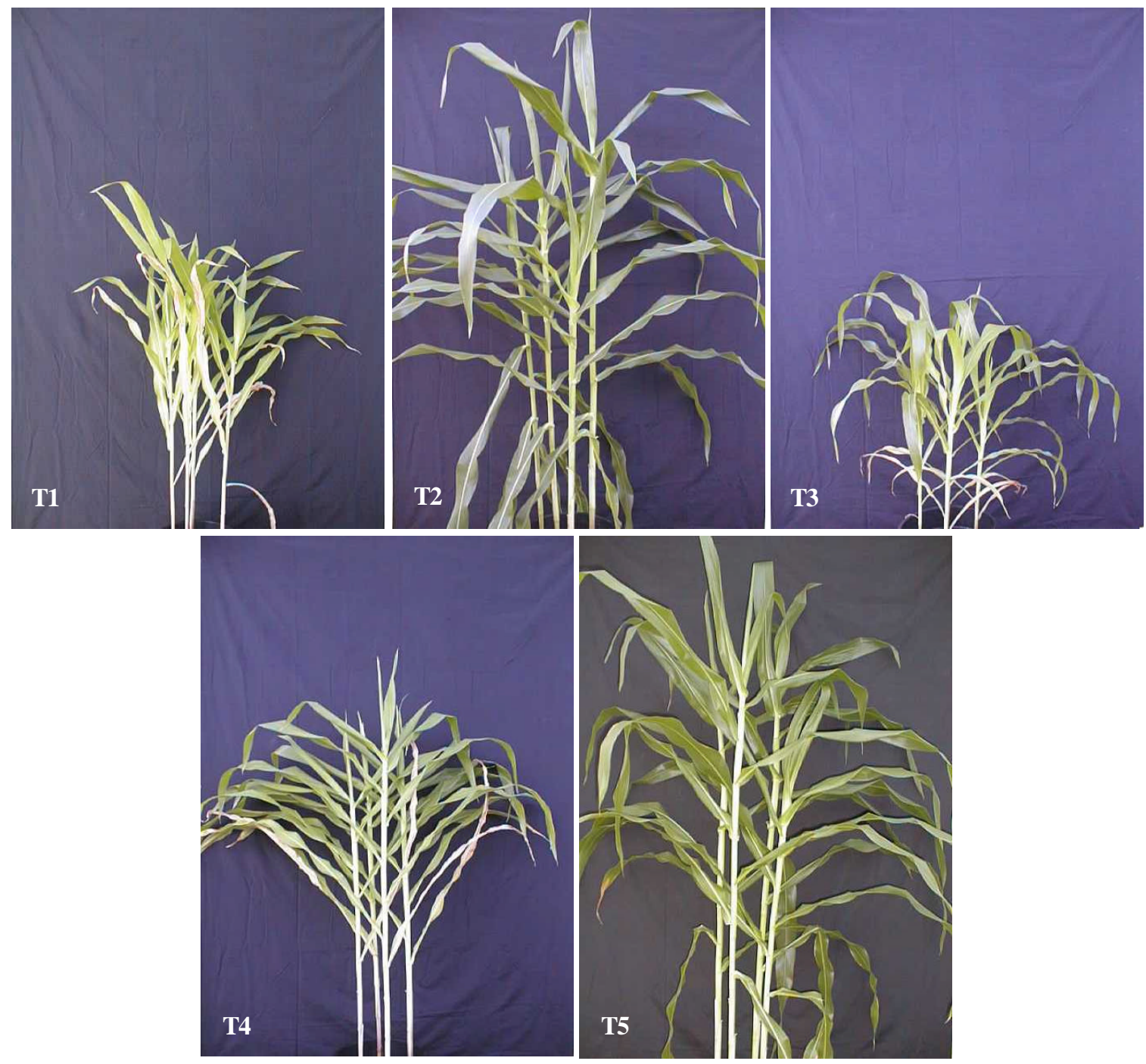

Figura 5 - Efeitos da aplicação do efluente secundário de esgoto tratado e/ou adubação nitrogenada nas plantas de milho, 58 dias após a emergência. T1 = irrigação com água deionizada e adubação mineral completa, exceto N; T2 = irrigação com água deionizada e adubação mineral completa; T3 = somente irrigação com efluente, sem nenhuma adição de fertilizante mineral; T4 = irrigação com efluente e adubação mineral completa, exceto $\mathrm{N}$; T5 = irrigação com efluente e adubação mineral completa. 
Tabela 15. Efeitos de fontes d'água para irrigação (efluente e água deionizada) e adubação no conteúdo de macronutrientes, pelas folhas, colmos e toda parte aérea das plantas de milho, 58 dias após a emergência.

\begin{tabular}{|c|c|c|c|c|c|c|}
\hline Tratamento & $\mathrm{N}$ & $\overline{\mathrm{P}}$ & $\mathrm{K}$ & $\mathrm{Ca}$ & $\mathrm{Mg}$ & $\bar{S}$ \\
\hline & \multicolumn{6}{|c|}{ Acúmulo pelas folhas, $\mathrm{mg} \mathrm{vaso}^{-1}$} \\
\hline $\mathrm{T} 1{ }^{(1)}$ & $210 c^{(7)}$ & $48,0 \mathrm{~d}$ & $443 d$ & $141,2 \mathrm{c}$ & $57,6 \mathrm{c}$ & $37,3 \mathrm{c}$ \\
\hline $\mathrm{T} 2^{(2)}$ & $1284 \mathrm{a}$ & $132,7 \mathrm{~b}$ & $938 \mathrm{~b}$ & $448,2 \mathrm{a}$ & $217,5 \mathrm{a}$ & $138,1 \mathrm{a}$ \\
\hline $\mathrm{T} 3^{(3)}$ & $268 \mathrm{bc}$ & $27,2 \mathrm{e}$ & $234 \mathrm{e}$ & $57,8 \mathrm{~d}$ & $78,4 \mathrm{bc}$ & $21,5 \mathrm{c}$ \\
\hline $\mathrm{T} 4^{(4)}$ & $490 \mathrm{~b}$ & $81,8 \mathrm{c}$ & $685 c$ & $163,3 \mathrm{c}$ & $96,4 \mathrm{~b}$ & $39,3 \mathrm{c}$ \\
\hline $\mathrm{T} 5^{(5)}$ & $1490 \mathrm{a}$ & $174,4 \mathrm{a}$ & $1145 \mathrm{a}$ & $310,0 \mathrm{~b}$ & $210,7 \mathrm{a}$ & $105,4 \mathrm{~b}$ \\
\hline \multirow[t]{2}{*}{ C.V. $(\%)^{(6)}$} & 15,7 & 10,9 & 10,4 & 13,9 & 13,8 & 14,0 \\
\hline & \multicolumn{6}{|c|}{ Acúmulo pelos colmos, mg vaso ${ }^{-1}$} \\
\hline $\mathrm{T} 1$ & $156 \mathrm{c}$ & $95,2 \mathrm{c}$ & $700 \mathrm{~b}$ & $64,2 \mathrm{c}$ & $50,9 \mathrm{c}$ & $12,5 \mathrm{~d}$ \\
\hline $\mathrm{T} 2$ & $892 \mathrm{a}$ & $152,6 \mathrm{~b}$ & $672 \mathrm{~b}$ & $148,4 \mathrm{a}$ & $175,5 \mathrm{a}$ & $66,8 \mathrm{~b}$ \\
\hline $\mathrm{T} 3$ & $74 \mathrm{c}$ & $16,1 \mathrm{~d}$ & $149 \mathrm{c}$ & $10,25 \mathrm{~d}$ & 36,2 c & $5,3 \mathrm{e}$ \\
\hline $\mathrm{T} 4$ & $412 b$ & $151,9 \mathrm{~b}$ & $1064 \mathrm{a}$ & $93,8 \mathrm{~b}$ & $118,4 \mathrm{~b}$ & $23,7 \mathrm{c}$ \\
\hline T5 & $956 \mathrm{a}$ & $183,3 \mathrm{a}$ & $905 \mathrm{a}$ & $134,2 \mathrm{a}$ & $179,1 \mathrm{a}$ & $83,3 \mathrm{a}$ \\
\hline \multirow[t]{2}{*}{ C.V. (\%) } & 14,0 & 9,7 & 13,3 & 16,3 & 14,8 & 8,1 \\
\hline & \multicolumn{6}{|c|}{ Acúmulo por toda parte aérea, mg vaso ${ }^{-1}$} \\
\hline $\mathrm{T} 1$ & $366 \mathrm{c}$ & $143,1 \mathrm{~d}$ & $1143 \mathrm{c}$ & $205,4 \mathrm{c}$ & $108,5 \mathrm{c}$ & $49,8 \mathrm{~b}$ \\
\hline $\mathrm{T} 2$ & $2176 \mathrm{a}$ & $285,3 \mathrm{~b}$ & $1610 \mathrm{~b}$ & 596,6 a & $393,0 \mathrm{a}$ & $204,9 \mathrm{a}$ \\
\hline $\mathrm{T} 3$ & $342 \mathrm{c}$ & $43,3 \mathrm{e}$ & $383 \mathrm{~d}$ & $68,0 \mathrm{~d}$ & $114,6 \mathrm{c}$ & $26,8 \mathrm{c}$ \\
\hline $\mathrm{T} 4$ & $902 b$ & $233,6 \mathrm{c}$ & $1749 \mathrm{~b}$ & $257,1 \mathrm{c}$ & $214,8 b$ & $63,0 \mathrm{~b}$ \\
\hline T5 & $2446 \mathrm{a}$ & $357,7 \mathrm{a}$ & $2050 \mathrm{a}$ & $444,2 \mathrm{~b}$ & 389,8 a & $188,7 \mathrm{a}$ \\
\hline C.V. $(\%)$ & 11,7 & 7,6 & 9,4 & 9,8 & 12,0 & 9,2 \\
\hline \multicolumn{7}{|c|}{ 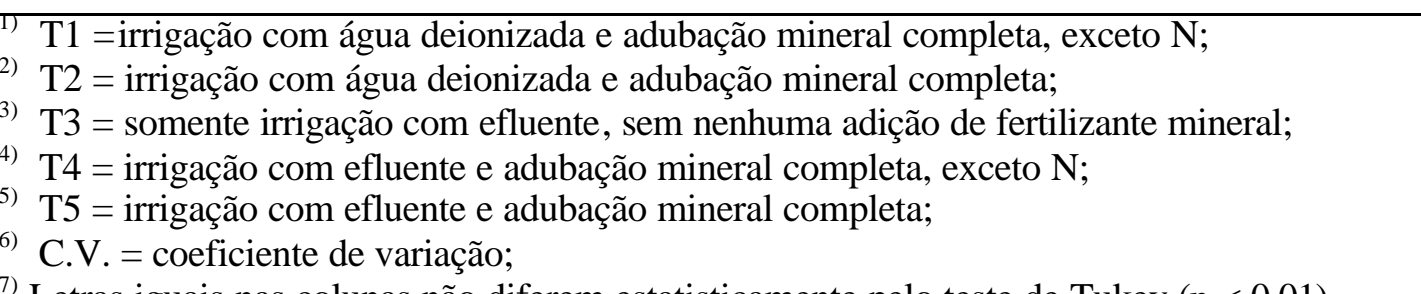 } \\
\hline
\end{tabular}

Foram iguais, nos tratamentos T3 e T4, o conteúdo de N, Mg, S (Tabela 15) e $\mathrm{Cu}$ (Tabela 16) pelas folhas e de Na (Tabela 16) por toda parte aérea. Para esses mesmos tratamentos, as plantas que receberam fertilização mineral (T4) tiveram maior acúmulo de P, K, Ca (Tabela 15), B, Fe, Mn e Zn (Tabela 16) pelas folhas, de todos os nutrientes 
pelos colmos (Tabelas 15 e 16) e de macronutrientes e micronutrientes por toda parte aérea, com exceção do $\mathrm{Na}$ (Tabelas 15 e 16).

Tabela 16. Efeitos de fontes d'água para irrigação (efluente e água deionizada) e adubação no conteúdo de $\mathrm{Na}$ e micronutrientes pelas folhas, colmos e toda parte aérea das plantas de milho, 58 dias após a emergência.

\begin{tabular}{|c|c|c|c|c|c|c|}
\hline Tratamento & $\mathrm{Na}$ & $\mathrm{B}$ & $\mathrm{Cu}$ & $\mathrm{Fe}$ & $\mathrm{Mn}$ & $\mathrm{Zn}$ \\
\hline & \multicolumn{6}{|c|}{ Acúmulo pelas folhas, $\mathrm{mg}$ vaso $^{-1}$} \\
\hline $\mathrm{T} 1{ }^{(1)}$ & $3,1 \mathrm{~d}^{(7)}$ & $1,04 \mathrm{c}$ & $0,08 \mathrm{~d}^{(6)}$ & $5,0 \mathrm{~cd}$ & $3,8 \mathrm{bc}$ & $0,37 \mathrm{bc}$ \\
\hline $\mathrm{T} 2^{(2)}$ & $8,9 \mathrm{~cd}$ & $1,55 \mathrm{ab}$ & $0,24 \mathrm{~b}$ & $13,9 \mathrm{a}$ & $12,8 \mathrm{a}$ & $1,85 \mathrm{a}$ \\
\hline $\mathrm{T} 3^{(3)}$ & $71,2 \mathrm{a}$ & $0,33 \mathrm{~d}$ & $0,12 \mathrm{~cd}$ & $2,5 \mathrm{~d}$ & $1,0 \mathrm{c}$ & $0,24 \mathrm{c}$ \\
\hline $\mathrm{T} 4^{(4)}$ & $19,0 \mathrm{c}$ & $1,28 \mathrm{bc}$ & $0,15 \mathrm{c}$ & $7,3 \mathrm{bc}$ & $6,1 \mathrm{~b}$ & $0,64 \mathrm{~b}$ \\
\hline $\mathrm{T} 5^{(5)}$ & $40,8 \mathrm{~b}$ & $1,77 \mathrm{a}$ & $0,30 \mathrm{a}$ & $10,4 \mathrm{ab}$ & $10,2 \mathrm{a}$ & $1,52 \mathrm{a}$ \\
\hline \multirow[t]{2}{*}{ C.V. $(\%)^{(6)}$} & 18,5 & 13,1 & 14,8 & 23,2 & 23,2 & 21,7 \\
\hline & \multicolumn{6}{|c|}{ Acúmulo pelos colmos, mg vaso ${ }^{-1}$} \\
\hline $\mathrm{T} 1$ & $2,0 \mathrm{~d}$ & $0,24 \mathrm{c}$ & $0,05 \mathrm{~d}$ & $0,8 \mathrm{~cd}$ & $3,8 \mathrm{ab}$ & $1,44 \mathrm{~b}$ \\
\hline $\mathrm{T} 2$ & $5,4 \mathrm{~d}$ & $0,92 \mathrm{a}$ & $0,29 \mathrm{a}$ & $3,4 \mathrm{~b}$ & $4,9 \mathrm{a}$ & $2,05 \mathrm{a}$ \\
\hline $\mathrm{T} 3$ & $147,2 \mathrm{c}$ & $0,10 \mathrm{~d}$ & $0,03 \mathrm{~d}$ & $0,3 \mathrm{~d}$ & $0,2 \mathrm{c}$ & $0,10 \mathrm{~d}$ \\
\hline $\mathrm{T} 4$ & $295,0 \mathrm{~b}$ & $0,68 \mathrm{~b}$ & $0,11 \mathrm{c}$ & $1,1 \mathrm{c}$ & $3,6 \mathrm{~b}$ & $0,85 \mathrm{c}$ \\
\hline T5 & 544,7 a & $0,85 \mathrm{a}$ & $0,23 \mathrm{~b}$ & $4,4 \mathrm{a}$ & $4,1 \mathrm{ab}$ & $1,21 \mathrm{~b}$ \\
\hline \multirow[t]{2}{*}{ C.V. (\%) } & 26,0 & 12,4 & 19,8 & 14,1 & 18,8 & 16,3 \\
\hline & \multicolumn{6}{|c|}{ Acúmulo por toda parte aérea, $\mathrm{mg}$ vaso $^{-1}$} \\
\hline $\mathrm{T} 1$ & $5,1 \mathrm{c}$ & $1,28 \mathrm{c}$ & $0,13 \mathrm{c}$ & $5,8 \mathrm{bc}$ & $7,6 \mathrm{~b}$ & $1,81 \mathrm{c}$ \\
\hline $\mathrm{T} 2$ & $14,3 \mathrm{c}$ & $2,47 \mathrm{a}$ & $0,52 \mathrm{a}$ & $17,3 \mathrm{a}$ & $17,7 \mathrm{a}$ & $3,90 \mathrm{a}$ \\
\hline T3 & $218,4 \mathrm{~b}$ & $0,42 \mathrm{~d}$ & $0,15 \mathrm{c}$ & $2,8 \mathrm{c}$ & $1,2 \mathrm{c}$ & $0,34 \mathrm{~d}$ \\
\hline $\mathrm{T} 4$ & $314,0 \mathrm{~b}$ & $1,96 \mathrm{~b}$ & $0,25 \mathrm{~b}$ & $8,4 \mathrm{~b}$ & $9,7 \mathrm{~b}$ & $1,49 \mathrm{c}$ \\
\hline $\mathrm{T} 5$ & 585,5 a & $2,62 \mathrm{a}$ & $0,53 \mathrm{a}$ & $14,8 \mathrm{a}$ & $14,3 \mathrm{a}$ & $2,73 \mathrm{~b}$ \\
\hline C.V. $(\%)$ & 23,3 & 11,2 & 13,4 & 19,0 & 19,0 & 13,4 \\
\hline \multicolumn{7}{|c|}{$\begin{array}{l}\text { 2) T1 = irrigação com água deionizada e adubação mineral completa, exceto N; } \\
\text { T2 = irrigação com água deionizada e adubação mineral completa; } \\
\text { T3 = somente irrigação com efluente, sem nenhuma adição de fertilizante mineral; } \\
\text { (4) } \text { T4 = irrigação com efluente e adubação mineral completa, exceto N; } \\
\text { 55 = irrigação com efluente e adubação mineral completa; } \\
\text { 6. } \text { C. = coeficiente de variação; }\end{array}$} \\
\hline
\end{tabular}


Os tratamentos fertilizados e irrigados com água (T1 e T2) tiveram menor acúmulo de K (Tabela 15) e Na (Tabela 16) pelos colmos do que os tratamentos fertilizados e irrigados com ESET.

Comparando-se os tratamentos irrigados com água (T1 e T2), as plantas que receberam fertilização nitrogenada mineral (T2) tiveram maior acúmulo de $\mathrm{N}, \mathrm{P}, \mathrm{Ca}$, Mg, S (Tabela 15) B, Cu, Fe e Zn (Tabela 16) pelos colmos, de macronutrientes (Tabela 15) e de micronutrientes (Tabela 16) pelas folhas e por toda parte aérea. No entanto, esses tratamentos acumularam a mesma quantidade de K (Tabela 15) e Mn pelos colmos (Tabela 16) e de $\mathrm{Na}$ (Tabela 16) pelas folhas, colmos e toda parte aérea.

Quando as plantas foram fertilizadas adequadamente (T2 e T5), as que receberam efluente tiveram maior acúmulo de $\mathrm{P}, \mathrm{K}$ (Tabela 15), $\mathrm{Na}$ e $\mathrm{Cu}$ (Tabela 16) pelas folhas, P, K, S (Tabela 15), Na e Fe (Tabela 16) pelos colmos e de P, K (Tabela 15) e Na (Tabela 16) por toda parte aérea. Para os mesmos tratamentos, quando as plantas receberam irrigação com ESET, elas tiveram menor conteúdo de Ca e $\mathrm{S}$ pelas folhas (Tabela 15), $\mathrm{Cu}$ e $\mathrm{Zn}$ pelos colmos (Tabela 16) e de Ca (Tabela 15) e Zn (Tabela 16) por toda parte aérea. Porém, foram iguais as absorções de $\mathrm{N}, \mathrm{Mg}$ (Tabela 15), Na, B, Fe, Mn e Zn (Tabela 16) pelas folhas, de N, Ca, Mg (Tabela 15), B e Mn (Tabela 16) pelos colmos e de N, Mg, S (Tabela 15) e micronutrientes, com exceção do Zn, por toda parte aérea (Tabela 16).

$\mathrm{O}$ acúmulo de Na pela parte aérea das plantas de milho, mediante a irrigação com ESET, aumentou de 15,3 até 40,1 vezes, principalmente nos colmos, comparandose àquelas plantas adubadas adequadamente e irrigadas com água deionizada. Esse aumento no conteúdo de $\mathrm{Na}$ foi até mais de 100 vezes nos colmos das plantas que receberam maior quantidade de irrigação com efluente (Tabela 15).

A fertilização nitrogenada mineral (T2 e T5), independentemente do tipo d'água de irrigação empregada neste experimento, foi a maior responsável pela produção de matéria seca pelas folhas, colmos e da parte aérea das plantas de milho como um todo (Tabela 17). Ainda, a fertilização nitrogenada mineral ocasionou maiores teores de clorofila (por medição indireta) e de N (Tabela 17). 
Comparando-se os tratamentos que não receberam fertilização nitrogenada mineral, a irrigação com efluente contribuiu para o aumento nos teores de $\mathrm{N}$ e de clorofila e ainda, incrementou a produção de matéria seca pelas plantas de milho na ausência de fertilização nitrogenada mineral quando os demais nutrientes encontravamse em teores adequados (Tabela 17).

Tabela 17. Efeitos de fontes d'água para irrigação (efluente e água deionizada) e adubação na concentração de nitrogênio e clorofila, medidas na terceira folha completamente expandida e na produção de matéria seca pelas folhas, colmos e toda parte aérea das plantas de milho, 58 dias após a emergência.

\begin{tabular}{|c|c|c|c|c|c|}
\hline \multirow[t]{2}{*}{ Tratamento } & \multirow{2}{*}{$\begin{array}{c}\text { Concentração de } \\
\mathrm{N}\end{array}$} & \multirow{2}{*}{$\begin{array}{l}\text { Unidades } \\
\text { SPAD }^{(1)}\end{array}$} & \multicolumn{3}{|c|}{ Produção de matéria seca } \\
\hline & & & Folhas & Colmos & Parte aérea \\
\hline & $\mathrm{g} \mathrm{kg}^{-1}$ & & & g $\operatorname{vaso}^{-1}$ & ---- \\
\hline $\mathrm{T} 1{ }^{(2)}$ & $8,0 \mathrm{~d}^{(8)}$ & $17,2 \mathrm{c}$ & $28,1 \mathrm{c}$ & $27,0 \mathrm{c}$ & $55,2 \mathrm{c}$ \\
\hline $\mathrm{T} 2^{(3)}$ & $20,6 \mathrm{a}$ & $39,5 \mathrm{a}$ & $61,0 \mathrm{a}$ & $67,7 \mathrm{a}$ & $128,7 \mathrm{a}$ \\
\hline $\mathrm{T} 3^{(4)}$ & $16,3 \mathrm{~b}$ & $26,4 \mathrm{~b}$ & $16,4 \mathrm{~d}$ & $6,7 \mathrm{~d}$ & $23,1 \mathrm{~d}$ \\
\hline $\mathrm{T} 4^{(5)}$ & $11,4 \mathrm{c}$ & $24,2 \mathrm{~b}$ & $42,7 \mathrm{~b}$ & $47,3 \mathrm{~b}$ & $90,0 \mathrm{~b}$ \\
\hline $\mathrm{T} 5^{(6)}$ & $19,7 \mathrm{a}$ & $40,4 \mathrm{a}$ & 66,0 a & $76,6 \mathrm{a}$ & $142,6 \mathrm{a}$ \\
\hline C.V. $(\%)^{(7)}$ & 8,7 & 7,3 & 9,6 & 11,4 & 9,5 \\
\hline
\end{tabular}

(1) Unidades SPAD dadas pela medição indireta da clorofila;

(2) T1 =irrigação com água deionizada e adubação mineral completa, exceto N;

(3) T2 = irrigação com água deionizada e adubação mineral completa;

(4) T3 = somente irrigação com efluente, sem nenhuma adição de fertilizante mineral;

(5) T4 = irrigação com efluente e adubação mineral completa, exceto N;

(6) T5 = irrigação com efluente e adubação mineral completa;

(7) C.V. = coeficiente de variação;

(8) Letras iguais nas colunas não diferem estatisticamente pelo teste de Tukey $(p<0,01)$.

As plantas que não receberam fertilização mineral, mas foram irrigadas com ESET (T3), tiveram maiores teores de $\mathrm{N}$ e de clorofila em relação às plantas que receberam fertilizantes minerais, exceto $\mathrm{N}$ e irrigação com água deionizada (Tabela 17). Todavia, na ausência total de fertilizantes minerais, ocorreu a menor produção de matéria seca pelas diferentes partes das plantas de milho (folhas, colmos e toda parte aérea). 


\subsubsection{Discussão dos resultados}

\subsubsection{Considerações sobre o efluente utilizado no experimento}

O ESET utilizado neste experimento (Tabela 5) apresenta uma composição em nutrientes e demais constituintes que acompanham as médias apresentadas na literatura (Feigin et al., 1991; Pescod, 1992). Os teores de metais pesados são bem inferiores aos limites apresentados em Ayers \& Westcot (1985), pelo fato desse efluente ser oriundo de uma cidade não industrializada.

Porém o Na, pelo fato de ter sido o elemento presente em maior concentração, foi o responsável pela elevada RAS do ESET, conduzindo este efluente a uma classe com severa restrição de uso para irrigação por superfície (Ayers \& Westcot, 1985). Pelo fato da qualidade da água consumida pela população estar diretamente relacionada à qualidade do efluente (Feigin et al., 1991), o elevado teor de Na na água de Lins (Tabela 10) pode ter sido o responsável pela alta concentração de Na no efluente. Salienta-se que até mesmo se a água consumida pela população de Lins (SP) fosse destinada à irrigação de culturas, ela apresentaria risco severo de permeabilidade do solo (Ayers \& Westcot, 1995).

Do ponto de vista nutricional das plantas, se o efluente for pobre em $\mathrm{K}$ e rico

em $\mathrm{Na}$, para que sua disposição no solo seja sustentável, torna-se necessário a suplementação potássica das plantas, sobretudo na cultura do milho, para manter adequada a absorção de nutrientes e a produtividade (Karlen et al., 1976). Todavia, a disposição sustentável do ESET de Lins no solo exigirá um manejo especial com relação ao Na para que o risco de sodicidade seja evitado.

\subsubsection{Acidez ativa, potencial e trocável}

Espera-se que nos experimentos em vasos, uma vez que não há lixiviação, a acidificação das amostras de terra tenha ocorrido, principalmente, pela absorção de nutrientes, mineralização da matéria orgânica e reação de nitrificação. Assim, quando as plantas absorvem um cátion monovalente, elas eliminam um íon $\mathrm{H}^{+}$, aumentando a acidez na rizosfera (Mengel \& Kirkby, 1987). Durante a mineralização da matéria 
orgânica, ocorre o desprendimento de $\mathrm{CO}_{2}$, cuja dissolução para a forma de ácido carbônico $\left(\mathrm{H}_{2} \mathrm{CO}_{3}\right)$ e a síntese e dissociação do $\mathrm{H}_{2} \mathrm{CO}_{3}$ (eq. 2), constituem-se nas duas principais fontes de íons $\mathrm{H}^{+}$durante o ciclo do C (Bolan et al., 1991). Durante o processo de nitrificação do $\mathrm{NH}_{4}{ }^{+}$(eq. 4) pelos microrganismos (Nitrosomonas e Nitrobacter), ocorre a liberação de prótons para o sistema (Bolan et al., 1991), contribuindo para diminuição do pH.

$$
\mathrm{NH}_{4}^{+}+2 \mathrm{O}_{2} \rightarrow \mathrm{NO}_{3}^{-}+\mathrm{H}_{2} \mathrm{O}+2 \mathrm{H}^{+}
$$

Possivelmente, todos esses processos descritos anteriormente ocorreram nas unidades experimentais. Todavia, o uso de ESET como fonte d'água para irrigação contribuiu para que a acidificação das amostras de solo fosse menos intensa, notadamente no tratamento T5 (Tabela 12), o qual recebeu adubação nitrogenada na forma de uréia (Tabela 6), cujo fertilizante tem poder acidificante (Raij, 1991).

Os resultados foram consistentes, pois a medida que o $\mathrm{pH}$ era mais elevado, a acidez trocável e potencial foram menores, mostrando o efeito do ESET como amenizador da acidez do solo (Tabela 12). Também, esse incremento de $\mathrm{pH}$ foi menor que uma unidade, condizente com os resultados encontrados na literatura (Quin \& Woods, 1978; Johns \& McConchie, 1994a; Smith et al., 1996b; AlNakshabandi et al., 1997; Speir et al., 1999). Falkiner \& Smith (1997) não somente observaram aumento no pH pela adição de ESET, mas também redução no teor de Al.

Apesar de normalmente não haver grandes mudanças no $\mathrm{pH}$ do solo por influência do pH da água de irrigação (Bouwer \& Idelovitch, 1987), neste experimento, vários fatores podem ter corroborados para a alteração do $\mathrm{pH}$ das amostras de solo que receberam ESET, independentemente se foram ou não fertilizadas com adubo nitrogenado mineral (Tabela 12). Esse aumento de $\mathrm{pH}$ certamente ocorreu devido à baixa CTC da amostra de terra (Tabela 4) utilizada no experimento (baixo poder tampão); menor absorção e acúmulo de nutrientes nas amostras com maior valor de $\mathrm{pH}$ (Tabelas 15 e 16); aporte de $\mathrm{HCO}_{3}{ }^{-}$nas unidades experimentais pelo emprego de ESET (Tabela 11), bem como do pH alto do mesmo (Stewart et al., 1990) associado às altas concentrações de $\mathrm{Na}^{+}$e $\mathrm{CO}_{3}{ }^{2-}$ (Bouwer \& Idelovitch, 1987); adição de cátions trocáveis e de ânions oriundos do efluente (Falkiner \& Smith, 1997); possível descarboxilação de 
ânions orgânicos e desaminação de aminoácidos (Yan et al., 1996) da fração orgânica do efluente, dominada por algas mortas (Snow et al., 1999); e à denitrificação de $\mathrm{NO}_{3}{ }^{-}$ (Bolan et al., 1991), cujo processo tem sido incrementado nos solos irrigados com efluentes (Schipper et al., 1996; Friedel et al., 2000).

\subsubsection{Carbono, fósforo e enxofre}

Os teores de COT não foram influenciados pelos tratamentos (Tabela 12), provavelmente pelo curto período de duração deste experimento ou pela rápida decomposição da matéria orgânica do efluente adicionada às unidades experimentais, uma vez que as condições de umidade, temperatura (Figura 2) e oxigenação do ambiente, associadas à baixa relação $\mathrm{C} / \mathrm{N}$ do efluente (Tabela 5), corroboraram para rápida degradação do material orgânico. Somente tem sido verificado alterações na dinâmica do $\mathrm{C}$ em solos irrigados com efluente por mais de dois anos, conforme observado nos experimentos realizados por Quin \& Woods (1978), Latterell et al. (1982), Polglase et al. (1995), Falkiner \& Smith (1997) e Friedel et al. (2000). Também, é possível que o aporte de MOT pelo emprego de ESET tenha sido tão pequeno (Tabela 11) que o método analítico utilizado não foi capaz de detectar.

$\mathrm{O}$ fertilizante fosfatado foi o responsável pelo aumento nos teores de $\mathrm{P}$ nas amostras de solo (Tabela 12) e foi o maior limitante na produção de matéria seca pelas plantas de milho na ausência de fertilização mineral, cuja carência nutricional surgiu aos 11 DAE. Destaca-se que o efluente, apesar de ter ocasionado maior acúmulo deste nutriente pelas folhas, colmos e toda parte aérea das plantas de milho do tratamento T5 (Tabela 15), não alterou o teor deste nutriente no solo (Tabela 12). Vazquez-Montiel et al. (1996) também verificaram maior absorção de P pelas plantas de milho fertilizadas e irrigadas com efluente e Al-Jaloud et al. (1995) observaram aumento na concentração de $\mathrm{P}$ nas folhas de milho pelo emprego de efluente, cujo fato foi atribuído à presença deste nutriente na água residuária.

Nas unidades experimentais não fertilizadas com $\mathrm{P}$, apesar de exibirem menor teor de P-disponível (Tabela 12), apresentaram maior teor de $\mathrm{P}$ no final do experimento do que na amostragem inicial (Tabela 4), anterior à calagem e ao cultivo das plantas. 
Certamente, os pequenos incrementos na disponibilidade de $\mathrm{P}$ provocados pelo aumento de pH devido à calagem, a qual libera fosfatos adsorvidos (Raij, 1991) e o aporte de Pefluente (Tabela 11), foram importantes para o crescimento das plantas de milho, apesar delas terem tido baixa produção de matéria seca (Tabela 17). Evidentemente, não se espera que o efluente venha substituir a adubação mineral, notadamente em solos com baixo teores de $\mathrm{P}$, como o do presente experimento, cuja composição mineralógica predominante é quartzo, caulinita, hematita e goethita. Assim, além do baixo teor Pdisponível natural desse solo, os óxidos de Fe presentes certamente contribuíram para maior fixação deste nutriente, afetando sua disponibilidade às plantas (Fassbender \& Bornemisza, 1987).

Embora vários trabalhos da literatura internacional relatam o fato do efluente ter nutrido adequadamente as plantas com P (Day \& Tucker, 1959; Day et al., 1962; Day et al., 1974; Day et al., 1975; Day \& Tucker, 1977), nenhum desses experimentos foram realizados em solo tropical ácido e de baixa fertilidade natural, como o do presente estudo, mas sim, em solos de região semi-árida e de alta fertilidade natural.

$\mathrm{O}$ aumento no teor de $\mathrm{P}$ mediante a adição de efluente, assim como o de $\mathrm{C}$, tem sido comum em solos que vêm recebendo este material por vários anos (Quin \& Woods, 1978; Hook, 1981; Goh \& Condron, 1989), notadamente aumento de P-orgânico (Latterell et al., 1982). Todavia, torna-se necessário estudos de campo, por longo período, para melhor compreender os processo que controlam a dinâmica do P-efluente no solo (Bond, 1998), mais precisamente nos solos com carga variável, os quais têm sido assumido que a sua capacidade em reter $\mathrm{P}$ contribui para evitar a lixiviação deste nutriente abaixo da zona radicular (Falkiner \& Polglase, 1997).

Embora Johns \& McConchie (1994b) verificaram aumento no teor de S no solo pelo emprego de efluente, tal fato não ocorreu no presente estudo (Tabela 12). Todavia, as unidades experimentais não fertilizadas (T3), semelhantemente ao P, tiveram menor teor de S (Tabela 12) devido ao fato da fonte fosfatada empregada ter sido o superfosfato simples, o qual contém em média 10-12\% de S (Raij, 1991). Assim, as plantas que cresceram nessas unidades experimentais acumularam menos $\mathrm{S}$ (Tabela 15), ao passo que as plantas fertilizadas adequadamente (T2 e T5), independentemente 
da fonte d'água, acumularam mais S pelos colmos e por toda parte aérea (Tabela 15), levando à ocorrência de maior produção de matéria seca (Tabela 17).

Assim como no caso do P, a amostra inicial (antes da calagem e instalação do experimento) apresentou menor teor de S (Tabela 4) do que após a colheita do experimento (Tabela 12). Esse fato indicou que a calagem, certamente pelo aumento de pH e liberação de sulfatos adsorvidos (Raij 1991), juntamente ao aporte de S-efluente (Tabela 11), constituíram-se numa fonte de $\mathrm{S}$ às plantas. Todavia, o fator $\mathrm{P}$ foi mais limitante (Figura 5), uma vez que não houve sintomas de deficiência de S nas plantas de milho. Salienta-se que o $\mathrm{S}$ tem sido pouco estudado nos solos utilizados para propósito de disposição de efluentes, com algumas exceções, como no trabalho de Johns \& McConchie (1994b), os quais avaliaram a dinâmica deste nutriente no sistema soloplanta-efluente.

\subsubsection{Nitrogênio e clorofila}

Os teores de NT nas amostras de solo não foram influenciados pela aplicação de efluente e nem pela fertilização mineral (Tabela 12). Esse fato indicou que todo $\mathrm{N}$ adicionado, ou foi absorvido pelas plantas, ou foi perdido do sistema e também, que a fração orgânica do N-efluente foi rapidamente disponibilizada. Assim, admite-se que tão logo o N-efluente atingiu o sistema solo-planta, ele passou a fazer parte do ciclo do $\mathrm{N}$ solo (Feigin et al., 1991). Aumentos nos teores de NT e N-mineral $\left(\mathrm{N}^{-\mathrm{NH}_{4}}{ }^{+}+\mathrm{N}^{-\mathrm{NO}_{3}}{ }^{-}\right)$ no solo pela irrigação com ESET, assim como no caso do COT e P, têm sido comum em locais que vem recebendo efluentes por longo período (Quin \& Woods, 1978; Latterell et al., 1982).

$\mathrm{O}$ efluente foi efetivo em aumentar o teor foliar de $\mathrm{N}$ e de clorofila (Tabela 17), o conteúdo de $\mathrm{N}$ (Tabela 15) e a produção de matéria seca pelas folhas, colmos e por toda parte aérea (Tabela 17), quando os demais nutrientes não eram limitantes. No entanto, esses incrementos não foram iguais ao efeito da fertilização nitrogenada mineral (Tabela 17), concordando com as observações de Feigin et al. (1981). Esses autores observaram que, em estudo com água deionizada, EET e solução mineral simulando a concentração de nutrientes contidos no efluente, o acúmulo de $\mathrm{N}$ pelo milho não foi 
afetado pela qualidade da água da irrigação e também, a disponibilidade de N-efluente foi menor que o $\mathrm{N}$ oriundo dos fertilizantes nitrogenados.

A menor eficiência do efluente como fertilizante nitroge nado pode ser devido, principalmente, a dois fatores. Primeiro, a demanda das plantas por água e $\mathrm{N}$ não terem sido paralelas. O requerimento por esse nutriente, pela maioria das culturas, é maior durante o período de crescimento ativo e menor durante os estádios iniciais e próximo ao período de colheita, enquanto a exigência de água é exatamente o contrário (Bouwer \& Idelovitch, 1987). Segundo, as perdas de $\mathrm{N}$ por volatilização, notadamente de $\mathrm{NH}_{3}$ (Smith et al.,1996a), em solos irrigados com efluente, têm sido consideravelmente altas (Polglase et al., 1995), pelo fato de os nutrientes serem deixados na superfície do solo (Feigin et al., 1981); secundariamente esta perda de N pode ocorrer por lixiviação de N$\mathrm{NO}_{3}{ }^{-}$(Hook \& Kardos, 1976; Polglase et al., 1995); e por denitrificação, uma vez que esse processo tem sido incrementado mediante a disposição de EET no solo (Schipper et al., 1996; Friedel et al., 2000)

$\mathrm{O}$ fato das plantas do tratamento T3 apresentarem maiores concentrações de $\mathrm{N}$ e de clorofila (medição indireta) que as plantas do tratamento T1 (Tabela 17), pode ser devido a três fatores. Primeiro, o teor de $\mathrm{N}$ no tecido foliar afetou diretamente a concentração de clorofila, pois houve uma correlação positiva altamente significativa entre teor de $\mathrm{N}$ e clorofila $(r=0,93 * *)$. Tal fato tem sido relatado na literatura (Malavolta et al., 1997). Segundo, o aporte de N-efluente no tratamento T3 foi, provavelmente, maior que a quantidade de $\mathrm{N}$ mineralizada nas amostras de terra. Isso pode ser inferido pois as plantas do tratamento T3, apesar de terem produzido menor quantidade de matéria seca que as plantas do tratamento T1 (Tabela 17), acumularam a mesma quantidade de $\mathrm{N}$ (Tabela 15). E finalmente, pelo fato das plantas do tratamento T3 terem acumulado 42,8 vezes mais $\mathrm{Na}$, principalmente pelas folhas (Tabela 16), é possível que os efeitos da sodicidade/salinidade, tais como, folhas mais espessas e com coloração verde escuro, pelo fato de haver maior quantidade de células por superfície (Feigin et al., 1991), possam ter cont ribuído para esse resultado.

Todavia, a curto prazo e em condições de casa-de-vegetação, as unidades experimentais fertilizadas adequadamente e irrigadas com ESET não apresentaram 
aumento no teor de NT no solo (Tabela 12) e nenhum efeito de excesso deste nutriente nos tecidos vegetais (Tabela 15), como relatado em Bielorai et al. (1984) e Feigin et al. (1984). Porém, torna-se necessário estudos mais aprofundados, principalmente conduzidos a campo, para averiguar o potencial do ESET em incrementar os teores de $\mathrm{N}$-mineral, notadamente de $\mathrm{N}-\mathrm{NO}_{3}{ }^{-}$no solo e na solução do solo.

\subsubsection{Cálcio, magnésio, potássio e sódio}

O tratamento T3 apresentou menor teor de Ca pelo fato de não ter recebido fertilização mineral (Tabela 12), uma vez que a fonte de $\mathrm{P}$ (superfosfato simples) empregada nos demais tratamentos, possuía gesso (Raij, 1991). O gesso $\left(\mathrm{CaSO}_{4} \cdot 2 \mathrm{H}_{2} \mathrm{O}\right)$ constitui-se numa importante fonte de Ca e S para o solo (Raij, 1988).

As unidades experimentais fertilizadas adequadamente e irrigadas com ESET (T5), apresentaram maior teor de Ca trocável (Tabela 12). Esse fato foi devido ao aporte de Ca pelo efluente (Falkiner \& Smith, 1997) e ao menor conteúdo deste nutriente encontrado nas folhas, colmos e toda parte aérea das plantas de milho (Tabela 15). Incrementos nos teores de Ca trocável foram relatados por Cromer et al. (1984), Speir et al. (1999) e Stewart et al. (1990) em solos florestais, Quin \& Woods (1978) em pastagem e Johns \& McConchie (1994b) em solos cultivados com bananeira. O menor conteúdo de Ca pelas plantas de milho pode ter sido devido ao aumento no acúmulo de $\mathrm{Na}$ pela adição de efluente. Apesar do Na poder substituir parcialmente o K em plantas $\mathrm{C}_{4}$ (como o milho), notadamente em funções não específicas (Malavolta et al., 1997), o aumento excessivo deste nutriente pode ocasionar diminuição no teor de Ca e até mesmo levar à deficiência (Tisdale et al., 1985).

A fertilização mineral ocasionou diminuição no teor de $\mathrm{Mg}$ trocável nas amostras de solo, independentemente do tipo d'água de irrigação (Tabela 12). Essa redução do $\mathrm{Mg}$ pode ser explicado pelo fato das plantas, mediante a fertilização mineral, terem maior crescimento, produzirem mais matéria seca (Tabela 17) e acumularem maior quantidade deste nutriente (Tabela 15). Assim, uma vez que as plantas foram fertilizadas adequadamente, o efluente não alterou os teores de Mg no solo (Tabela 12). Esse fato contrasta com os dados obtidos por Stewart et al. (1990) e Falkiner \& Smith 
(1997), os quais observaram aumento no teor de Mg pela disposição de EET no solo; porém, concorda com o trabalho de Johns \& McConchie (1994b), os quais verificaram aumento nos teores de $\mathrm{Ca}$ e $\mathrm{Na}$ no solo e nenhuma interferência na concentração de $\mathrm{Mg}$ trocável, pelo emprego de efluente na irrigação de plantas.

Aumento no teor de $\mathrm{K}$ trocável pela disposição de efluente no solo tem sido verificado por Cromer et al.(1984), Al-Nakshabandi et al. (1997) e Falkiner \& Smith (1997). Neste experimento ocorreu redução do teor de K na ausência de fertilização mineral (Tabela 12). Quando as unidades experimentais foram adequadamente fertilizadas, independentemente do tipo d'água de irrigação, os teores de $\mathrm{K}$ permaneceram iguais. Esse fato concorda com o trabalho de Johns \& McConchie (1994b), que verificaram que os teores de $\mathrm{K}$, assim como também os de $\mathrm{Mg}$, não foram alterados pela disposição de efluente no solo. Todavia, nas unidades experimentais que não receberam fertilização nitrogenada mineral, houve maior e menor teor de $\mathrm{K}$ no solo (Tabela 1) e acúmulo deste nutriente pelas plantas (Tabela 15), respectivamente. Isso pode ser explicado pelo fato de que as plantas, quando mal nutridas, cresceram menos, produziram menor quantidade de matéria seca, tiveram a absorção e o acúmulo de nutrientes prejudicados.

$\mathrm{O}$ efluente alterou a nutrição de $\mathrm{K}$ nas plantas (Tabela 15). Assim, nas unidades experimentais que receberam maior quantidade de ESET, houve, evidentemente maior acúmulo de K pelas plantas. AlJaloud et al. (1995) verificaram, também na cultura do milho, que a concentração de K nas folhas aumentou mediante a irrigação das plantas e tal efeito foi atribuído ao aporte deste nutriente pelo efluente.

$\mathrm{O}$ efeito interiônico entre $\mathrm{K}^{+}$e $\mathrm{Na}^{+}$, normalmente tem ocasionado aumento da concentração de Na no tecido vegetal em detrimento do K (Tisdale et al., 1985). Por outro lado, a alta concentração externa de $\mathrm{Na}^{+}$pode substituir o $\mathrm{Ca}^{2+}$ nos sítios de troca na superfície externa da membrana plasmática das células das raízes do milho (Lynch et al., 1987). AlJaloud et al. (1995) verificaram que o emprego de efluente na irrigação ocasionou, nas folhas de sorgo, aumento e diminuição nos teores de $\mathrm{Na}$ e K, respectivamente. Gadallah (1994) verificou efeito semelhante, porém nas folhas de beringela. Todavia, no presente estudo, o aumento no conteúdo de Na pelas folhas, 
colmos e toda parte aérea do milho, foi acompanhado de incremento no acúmulo de $\mathrm{K}$, com exceção das unidades experimentais que não receberam fertilização mineral (Tabela 15). Assim, uma vez que as plantas foram bem adubadas, o Na-efluente não afetou a produção de matéria seca pelas diferentes partes do milho (Tabela 17), apesar da quantidade acumulada deste nutriente ter sido aumentada em mais de 40 vezes.

$\mathrm{O}$ teor de $\mathrm{Na}$ nas amostras de terra aumentou mediante a adição de efluente e isso ocasionou aumento no conteúdo deste nutriente pela parte aérea. Isso pode ser atribuído ao fato do ESET ser rico em Na (Tabela 5). Todavia, tem sido comum na literatura o efeito do efluente em incrementar o teor de Na trocável no solo e/ou o PST (Quin \& Woods, 1978; Falkiner \& Smith, 1997; Bond, 1998; Balks et al., 1998).

A disposição de efluente no solo ocasionou aumento de até 15,4 vezes no teor de Na trocável (Tabela 12) e de até 13,2 vezes no PST, ou seja, o Na chegou a ocupar até 22,5\% da CTC (Tabela 13). Esses dados concordam com as informações existentes na literatura. Latterell et al. (1982) verificaram aumento no teor de $\mathrm{Na}$ de 3,5 a 25 vezes, em função da taxa de aplicação do efluente. O PST aumentou de 3,2 para 9,8\% no trabalho de Stewart et al. (1990) e de 2 para $25 \%$ no experimento realizado por Balks et al. (1998). Obviamente, os maiores valores de PST encontrados no presente estudo foram nas unidades experimentais que não receberam adubação mineral (Tabela 13). Assim, devido a baixa CTC deste solo, qualquer aporte de nutriente, bem como de Na, tem uma representatividade muito maior se comparado aos solos esmectíticos (elevada CTC) de Israel ou de outros locais onde o EET tem sido comumente utilizado na irrigação de plantas.

O aumento expressivo de Na trocável certamente foi o maior responsável pelo aumento da saturação por bases, cujo incremento se deu mediante a fertilização mineral e pronunciadamente nas unidades experimentais que receberam maior quantidade de irrigação com ESET (Tabela 13). Falkiner \& Smith (1997) observaram aumento no teor de cátions trocáveis $(\mathrm{Ca}, \mathrm{Mg}, \mathrm{K}$ e $\mathrm{Na})$, obviamente, aumento na saturação por bases, pelo uso de efluentes.

$\mathrm{O} \mathrm{Na}$ tem se mostrado mais efetivo na redução da $\mathrm{CH}$ (condutividade hidráulica) em solo ácido (Martin et al., 1964) e o risco de sodicidade do solo pela 
disposição de efluente tem sido bastante discutido (Feigin et al., 1991; Cameron et al., 1997; Bond, 1998). A elevada RAS e alta concentração de Na no ESET de Lins (Tabela 5) tem indicado para que o manejo deste elemento no solo deverá ser o principal obstáculo para a disposição sustentável deste ESET no sistema solo-planta (Tabela 9). Isso pelo fato de que águas (efluentes) com elevada RAS podem ocasionar deslocamento progressivo do $\mathrm{Ca}$ e $\mathrm{Mg}$ adsorvidos na superfície dos colóide levando a precipitação do $\mathrm{Ca}^{2+} \mathrm{e} \mathrm{Mg}^{2+}$ na forma de $\mathrm{CaCO}_{3}$ e $\mathrm{MgCO}_{3}$. Durante este processo, o $\mathrm{Na}^{+}$não se precipita e permanece solúvel, aumentando o PST, assim como a concentração dos íons $\mathrm{HCO}_{3}{ }^{-}$e $\mathrm{CO}_{3}{ }^{2-}$, levando ao incremento no valor de $\mathrm{pH}$ do solo (Ayers \& Westcot, 1985). Porém, para medir este risco de sodicidade, torna-se necessário experimentos de campo de longa duração, a campo e com diferentes culturas, empregando-se diferentes taxas de adição do efluente.

\subsubsection{Condutividade elétrica}

Tanto o uso de ESET quanto o de fertilizantes minerais ocasionaram aumento na CE (a qual está diretamente relacionada à concentração de sais) das amostras de solo, notadamente nas amostras que receberam adubação completa e maior quantidade de irrigação com ESET (Tabela 12). Os fertilizantes têm aumentado a concentração de sais na solução do solo (Tisdale et al., 1985) e este fato tem merecido bastante atenção (Raij, 1991). O aumento da CE do solo pelo uso de efluente tem sido amplamente relatado na literatura (Hortenstine, 1976; Latterell et al., 1982; Cromer et al., 1984; Johns \& McConchie, 1994b; Smith et al., 1996b; Al-Nakshabandi et al., 1997; Falkiner \& Smith, 1997; Speir et al.,1999). Em determinadas situações, esse aumento na salinidade do solo pode afetar a absorção d'água pelas plantas, devido a presença de uma maior concentração dos íons $\mathrm{Na}^{+}, \mathrm{Cl}$ e $\mathrm{HCO}_{3}{ }^{-}$na solução do solo (Bielorai et al., 1984).

Por outro lado, o uso de efluente têm diminuído a CE do solo em regiões semi-áridas, conforme verificado por Day et al. (1979), ou através da lixiviação e/ou absorção de sais pelas plantas mediante irrigação com efluente (Stewart, 1990). 


\subsubsection{Capacidade de troca catiônica efetiva e potencial}

Quanto maior foi a quantidade de irrigação aplicada às unidades experimentais, maior foi o valor da $\mathrm{CTC}_{\mathrm{e}}$ (Tabela 13). Esse fato pode ser explicado pelo aporte de $\mathrm{Ca}, \mathrm{Mg}$, $\mathrm{K}$ e principalmente, de $\mathrm{Na}$ mediante a disposição do ESET. Falkiner \& Smith (1997) também verificaram aumento desses cátions trocáveis no solo pelo emprego de efluente na irrigação de florestas. Os mesmo autores também observaram que houve aumento na $\mathrm{CTC}_{\mathrm{e}} \mathrm{e}$ tal fato foi atribuído a substituição de íons $\mathrm{H}^{+}$na superfície das argilas devido a adição de $\mathrm{Ca}, \mathrm{Mg}, \mathrm{K}, \mathrm{Na}$ e $\mathrm{HCO}_{3}{ }^{-}$pelo efluente.

No presente estudo foi verificado que a CTC do solo variou mediante a adubação mineral, principalmente quando a fertilização ocorreu associada à irrigação das unidades experimentais com ESET (Tabela 13). A fração argila da amostra de terra utilizada neste experimento era dominada por caulinita, hematita e goethita, ou seja, minerais com carga variável. Nos solos de carga variável, o desenvolvimento de cargas na superfície dos colóides depende do $\mathrm{pH}$, da força iônica (I) da solução do solo e de reações com ânions e cátions (Bolan et al., 1999). Desse modo, o aumento da CE (Tabela 12) e consequentemente da I (Tabela 14), pode ter ocasionado diminuição na espessura da dupla camada elétrica difusa (Bolan et al., 1999). De acordo com a teoria da dupla camada, aumentando-se a concentração salina, diminui-se o cancelamento mútuo das cargas positivas e negativas das duplas camadas elétricas entre si, já que a extensão da influência da carga elétrica da dupla camada no interior da fase líquida diminui com o aumento da concentração da solução (Raij, 1973). Também, é possível que, devido ao fato de não ter havido lixiviação nas amostras de terra (nos vasos), nem todos os cátions trocáveis (contra-íons) estavam adsorvidos ao complexo de troca. Alguns contra-íons $\left(\mathrm{Ca}^{2+}, \mathrm{Mg}^{2+}, \mathrm{K}^{+}, \mathrm{Na}^{+}\right.$e outros cátions trocáveis) poderiam estar

ligados aos co-íons ( $\mathrm{SO}_{4}{ }^{2-}, \mathrm{NO}_{3}{ }^{-}, \mathrm{Cl}^{-}$e outros ânions) na solução do solo e, mediante a extração pela resina, esses contra-íons são determinados como sendo cátions trocáveis. Mas na verdade, não estavam ocupando as cargas negativas no complexo argilo-húmico. 


\subsubsection{Micronutrientes e elementos tóxicos}

Apesar dos tratamentos não terem influenciado o teor de B nas amostras de solo (Tabela 13), maior conteúdo desse micronutriente foi verificado nas unidades experimentais que receberam adequada fertilização mineral, independentemente do tipo d'água de irrigação empregada (Tabela 16). Johns \& McConchie (1994a) verificaram que a bananeira absorveu $81 \%$ mais B quando esta recebeu irrigação com EET. Feigin et al. (1991) relataram que devido ao fato de o B-efluente ser oriundo basicamente de sabões e detergentes, este nutriente pode facilmente ter sua concentração na água residuária maior que $0,1-1,0 \mathrm{mg} \mathrm{L}^{-1}$, levando as plantas a apresentarem toxicidade. Todavia, no presente estudo, o aporte de B pelo efluente não ocasionou nenhum efeito no sistema solo-planta (Tabelas 13 e 16).

Os metais pesados $(\mathrm{Cd}, \mathrm{Cr}, \mathrm{Cu}, \mathrm{Ni}, \mathrm{Pb}$ e $\mathrm{Zn})$ não tiveram suas respectivas concentrações alteradas nas amostras de terra fertilizadas, independentemente se irrigadas com água ou ESET (Tabela 13). Esses resultados concordam com as observações realizadas por Inglés et al. (1992) para $\mathrm{Cd}$, Ni e Pb extraíveis em DTPA, Johns \& McConchie (1994a e 1994b) para Cd, Ni e Pb, Al-Jaloud et al. (1995) para Ni e Smith et al. (1996b) para $\mathrm{Cr}, \mathrm{Ni}, \mathrm{Pb}$ e $\mathrm{Zn}$ extraíveis em EDTA. Este fato pode ser explicado porque o ESET normalmente tem sido pobre em metais pesados (Bouwer \& Chaney, 1974; Feigin et al., 1991; Inglés et al., 1993; Johns \& McConchie, 1994a); a cidade de Lins não apresenta indústrias poluidoras com metais pesados, consequentemente, o ESET tem sido pobre em poluentes e também, o presente estudo teve curta duração.

Todavia, as informações do presente estudo discordam com alguns dados obtidos por Quin \& Syers (1978), Al-Jaloud et al. (1995) e Al-Nashabandi et al. (1997). No trabalho realizado por Al-Jaloud et al. (1995) o emprego de efluente na irrigação das plantas de milho diminuiu os teores de $\mathrm{Cu}, \mathrm{Fe}, \mathrm{Mn}$ e Zn. Porém, Quin \& Syers (1978) verificaram ligeiro aumento nos teores de $\mathrm{Co}, \mathrm{Cu}, \mathrm{Mn}$ e $\mathrm{Zn}$ em pastagens irrigadas por 16 anos com efluente e Al-Nakshabandi et al. (1997) verificaram aumento nos teores de $\mathrm{Cd}, \mathrm{Cu}, \mathrm{Fe}, \mathrm{Mn}, \mathrm{Pb}$ e $\mathrm{Zn}$ em solos cultivados com beringela e irrigados com EET. 
Menores teores de Fe e Mn foram observado nas unidades experimentais que não receberam fertilização mineral e/ou apenas fertilizante mineral nitrogenado (Tabela 13). Consequentemente, maiores teores de Fe e Mn foram observados na presença de fertilização mineral e/ou adubação nitrogenada, inclusive nas parcelas que receberam adição de ESET (T5). Isso pode ser explicado pela diminuição no valor de pH do solo, principalmente nas parcelas que receberam fertilização nitrogenada mineral (T2 e T5), uma vez que houve correlação negativa entre $\mathrm{pH}$ e $\mathrm{Fe}(r=-0,82 * *)$ e $\mathrm{Mn}(r=-0,54$ **). Assim, o aumento na absorção de Fe e Mn pelas plantas (Tabela 17) pode ser explicado pela maior disponibilidade desses micronutrientes nas amostras de terra com menor valor de pH (Tabelas 12 e 13). A solubilidade do Fe na solução do solo depende acima de tudo do $\mathrm{pH}$, pois para cada aumento de uma unidade de $\mathrm{pH}$, ocorre diminuição de 1000 e de 100 vezes na atividade das formas $\mathrm{Fe}^{3+}$ e $\mathrm{Fe}^{2+}$, respectivamente (Tisdale et al., 1985). O Mn, assim como o Fe, tem sido grandemente influenciado pelo $\mathrm{pH}$. Em condição aeróbia, a atividade de $\mathrm{Mn}^{2+}$ na solução do solo decresce, teoricamente, em 100 vezes para cada aumento de uma unidade de $\mathrm{pH}$ (Borkert, 1991). Johns \& McConchie (1994b) verificaram que a adição de efluente ao solo ocasionou diminuição no teor de Fe, principalmente próximo à superfície do solo; no entanto, esses mesmos autores também verificaram leve incremento no $\mathrm{pH}$ do solo pela disposição de efluente. Falkiner \& Smith (1997) verificaram que o aumento nos teores de $\mathrm{Ca}, \mathrm{Mg}, \mathrm{K}$ e $\mathrm{Na}$ e de alcalinidade, pela adição de EET, ocasionaram aumento no valor de $\mathrm{pH}$ do solo e consequentemente, diminuiu disponibilidade de Mn.

O menor conteúdo de metais pesados micronutrientes nas plantas do tratamento T3 pode ser explicado pelo fato delas não terem recebido fertilização mineral e o efluente ser pobre em metais pesados (Tabela 5), não nutrindo adequadamente as plantas com Cu, Fe, Mn e Zn (Tabela 16). Porém, AlJaloud et al. (1995) verificaram aumento nas concentrações foliares de $\mathrm{Cu}, \mathrm{Mn}$, Mo e $\mathrm{Zn}$ no milho, devido a presença desses nutrientes na água de irrigação (efluente). Desse modo, a pobreza em metais pesado do ESET de Lins, utilizado no presente estudo, constitui-se em um aspecto desejável para sustentabilidade da disposição deste resíduo no solo. 
Quando a fertilização nitrogenada mineral foi omitida, as plantas irrigadas com ESET tiveram acúmulo de $\mathrm{Cu}$ ligeiramente maior (Tabela 16). Todavia, este fato pode ser explicado pela seguinte hipótese: o efluente constituiu-se numa fonte parcial de $\mathrm{N}$; assim, quando as plantas receberam a irrigação com ESET, ela s tiraram proveito do $\mathrm{N}$-efluente, crescendo mais e consequentemente acumulando maior quantidade de matéria seca (Tabela 17) e de nutrientes (Tabelas 15 e 16), inclusive de Cu. Porém, é provável que este fato não tenha ocorrido devido a adição de ESET, uma vez que as plantas adubadas adequadamente acumularam a mesma quantidade de metais pesados micronutrientes pela parte aérea, independentemente se irrigadas com água ou efluente (Tabela 15).

O ESET de Lins não se mostrou problemático com relação aos metais pesados pelo menos a partir de ensaio de curta duração. Isso porque o emprego deste efluente na irrigação das plantas de milho não alterou a disponibilidade dos metais pesados (extraíveis em DTPA) e as concentrações de $\mathrm{Cd}, \mathrm{Cr}$ e $\mathrm{Ni}$ nos tecidos vegetais encontravam-se abaixo do limite de detecção.

\subsubsection{Produção de matéria seca}

Sem fertilizante nitrogenado mineral, as plantas que receberam ESET aproveitaram-se do $\mathrm{N}$ contido no efluente, produzindo maior quantidade de matéria seca (Tabela 17) e acumulando maior quantidade de nutrientes, quando comparadas às plantas irrigadas com água (Tabelas 15 e 16). Destaca-se que neste caso, embora a irrigação com efluente tenha adicionado $\mathrm{N}$ às unidades experimentais, a produção de matéria seca ficou muito aquém dos tratamentos que receberam fertilização nitrogenada mineral (T2 e T5). Esses dados concordam com os obtidos por Feigin et al. (1981), os quais observaram que, em estudo com água deionizada, efluente de esgoto e solução mineral simulando a concentração de nutrientes contidos no efluente, a absorção de N pelo milho não foi afetada pela qualidade da água da irrigação. Todavia, o aproveitamento do N-efluente foi um tanto menor que o $\mathrm{N}$ oriundo dos fertilizantes nitrogenados incorporados no solo (Feigin et al., 1981), certamente devido a maiores 
perdas por volatilização (Smith et al., 1996a) e/ou denitrificação (Schipper et al., 1996; Friedel et al., 2000).

As perdas de $\mathrm{N}$ podem ser altas nos resíduos orgânicos e $\mathrm{pH}$ alto, inclusive por volatilização de $\mathrm{NH}_{3}$, notadamente nos solos de baixa CTC (Stevenson, 1985). Isso certamente ocorreu no presente estudo, uma vez que o efluente não deixa de ser um resíduo orgânico líquido e alcalino (Tabela 5) e a amostra de terra utilizada neste experimento apresentava apenas $150 \mathrm{~g} \mathrm{~kg}^{-1}$ de argila (Tabela 4), com predomínio de caulinita. Também, as condições experimentais provavelmente favoreceram a ocorrência de denitrificação por vários motivos: (i) cerca de 21 DAE das plantas a taxa de infiltração do efluente nas amostras de solo que receberam maior quantidade de irrigação começou a diminuir e isso evidenciou menor aeração das amostras de terra; (ii) a temperatura média da casa-de-vegetação normalmente foi maior que a $25^{\circ} \mathrm{C}$ (Figura 2), acima da qual a denitrificação começa a tomar lugar; (iii) o pH das amostras de solo foi aumentado tanto pela calagem prévia à instalação do experimento como também pela própria adição do ESET (Tabela 12) e pH acima de 5,0 favorece a denitrificação; (iv) a adição de efluente às amostras de terra certamente ocasionou porte de C-solúvel, prontamente decomponível (Bouwer \& Chaney, 1974). Essas condições acima, segundo Stevenson (1985) levam a ocorrência de perdas gasosas de $\mathrm{N}$ por denitrificação biológica.

Uma vez que as plantas foram adequadamente fertilizadas, mesmo com aumento exagerado no teor de Na no solo (Tabela 12) e aumento expressivo no acúmulo deste elemento pelas plantas (Tabela 16), a produção de matéria seca não foi influenciada pela irrigação com efluente (Tabela 17). Certamente, a presença de outros elementos nutrientes no efluente neutralizaram o efeito indesejável da alta concentração de Na no ESET. Por outro lado, esse acréscimo de nutrientes devido a adição de ESET não foi suficiente para aumentar os teores de clorofila e nem a produção de matéria seca do milho (Tabela 17).

Assim, o EET foi efetivo apenas como fonte parcial de $\mathrm{N}$ (na omissão da adubação mineral desse nutriente) e substituiu adequadamente a água de irrigação. A substituição efetiva da água convencional pelo EET na irrigação tem apresentado 
sucesso não somente na cultura do milho (Karlen et al., 1976; Overman, 1981; AlJaloud et al., 1995; Vazquez-Montiel et al., 1996; Oron et al., 1999), mas também em outras culturas agrícolas, como por exemplo canola, cevada, sorgo, trigo, tomate (Day et al., 1962, 1974, 1975 e 1979; Bouwer \& Chaney, 1974; Day \& Tucker, 1977; Bielorai et al., 1984; Feigin et al., 1984 e 1991; Pescod, 1992; Al-Jaloud et al., 1996; Hussain et al., 1996; Hussain \& AlJaloud, 1998).

O fato do ESET não substituir completamente a fertilização mineral (Tabela 17) certamente foi devido à amostra de terra utilizada no presente estudo possuir baixa fertilidade natural, baixa CTC e ser paupérrima em P (Tabela 4). Desse modo, apenas a irrigação com ESET levou às plantas a apresentarem deficiência nutricional (Figura 5), comprometendo a produção de matéria seca (Tabela 17). Este fato concorda com os dados obtidos por Inglés et al. (1992) e Maurer \& Davies (1993), os quais verificaram que os EET são ricos em minerais, mas não podem ser a única fonte de nutriente às plantas, tornando-se necessário a suplementação via fertilizante, para se ter um balanço nutricional adequado às plantas, inclusive na cultura do milho (Overman et al., 1995). 


\section{CONCLUSÕES}

A adição de ESET aumentou a disponibilidade de $\mathrm{N}$-mineral nas amostras de terra, principalmente de $\mathrm{N}-\mathrm{NO}_{3}{ }^{-}$, cujo aumento se correlacionou linearmente com a taxa de aplicação do efluente. Porém, cerca de 30 a 50\% (média de 36\%) do Nefluente aplicado não foi recuperado, indicando possíveis perdas por volatilização de $\mathrm{NH}_{3}$ e/ou denitrificação.

O efluente foi efetivo em reduzir a capacidade de acidificação do solo pelo uso de fertilizante mineral nitrogenado e ainda aumentou a CE e a $\mathrm{CTC}_{\mathrm{e}}$.

O ESET não conseguiu substituir completamente a adubação mineral nitrogenada, apesar de ter ocasionado maior acúmulo de $\mathrm{N}$ e de matéria seca na omissão do fertilizante nitrogenado mineral, quando comparado em mesma situação de fertilização, mas irrigação com água.

Os teores de metais pesados no sistema solo-planta não foram influenciados pelo uso de ESET, uma vez que o efluente era pobre em metais pesados. Porém, o Na foi o constituinte do ESET mais problemático, pois o teor deste elemento nas amostras de terra e a seu conteúdo nas plantas aumentaram mais de 15 e 100 vezes, respectivamente.

O ESET não foi capaz de nutrir adequadamente as plantas com $\mathrm{P}$ na ausência de fertilização mineral. Para as plantas que receberam adubação completa, o efluente mostrou-se eficaz em substituir a água de irrigação, sem nenhum efeito negativo na produção de matéria seca e ainda, proporcionou maior acúmulo de K, P, Na.

Não é recomendável importar dados de pesquisas do exterior, cujas condições edafoclimáticas são completemente diferentes da situação brasileira e sobretudo, do Estado de São Paulo. São necessários estudos a campo, de longa duração, para avaliar o 
comportamento do sistema solo-planta-efluente, bem como o monitoramento de $\mathrm{N}^{-\mathrm{NO}_{3}}{ }^{-}$, $\mathrm{Na}$ e metais pesados. 


\section{REFERÊNCIAS BIBLIOGRÁFICAS}

ABREU, C.A.; ABREU, M.F. E ANDRADE, J.C. Determinação de cobre, ferro, manganês, zinco, cádmio, cromo, níquel e chumbo usando a solução de DTPA em pH 7,3. In: RAIJ, B.van; ANDRADE, J.C.; CANTARELLA, H.; QUAGGIO, J.A. (Ed.) Análise química para avaliação da fertilidade de solos tropicais. Campinas: Instituto Agronômico, 2001. p.240-250.

AL-JALOUD, A.A.; HUSSAIN, G.; AL-SAATI, A.J.; KARIMULLA, S. Effect of wastewater irrigation on mineral composition of corn and sorghum plants in a pot experiment. Journal of Plant Nutrition, v.18, p.1677-1692, 1995.

AL-JALOUD, A.A.; HUSSAIN, G.; KARIMULLA, S.; AL-HAMIDI, A.H. Effect of irrigation and nitrogen on yield and yield components of two rapeseed cultivars. Agricultural Water Management, v.30, p.57-68, 1996.

AL-NAKSHABANDI, G.A.; SAQQAR, M.M.; SHATANAWI, M.R.; FAYYAD, M.; AL-HORANI, H. Some environmental problems associated with the use of treated wastewater for irrigation in Jordan. Agricultural Water Management, v.34, p.8194, 1997.

ALLHANDS, M.N.; OVERMAN, A.R. Forage grass response to harvest interval and reclaimed water. Journal of Plant Nutrition, v.18, p.2723-2737, 1995.

ALVA, A.K.; SUMNER, M.E.; MILLER, W.P. Relationship between ionic strength and electrical conductivity for soil solutions. Soil Science, v.152, p.239-242, 1991.

AMERICAN PUBLIC HEALTH ASSOCIATION. Standard methods for the examination for water and wastewater. 18.ed. Washington, 1992. 70p.

ARAÚJO, W.F.; SAMPAIO, R.A.; MEDEIROS, R.D. Irrigação e adubação nitrogenada em milho. Scientia Agricola, v.56, p.909-914, 1999. 
ARTIOLA, J.F.; PEPPER, I.L. Longterm influence of liquid sewage sludge on the organic carbon and nitrogen content of a furrow-irrigated desert soil. Biology and Fertility of Soils, v.14, p.30-36, 1992.

AYERS, R.S.; WESTCOT, D.S. Water quality for agriculture. Rome: FAO, 1985. 174p. (Irrigation and Drainage Paper, 29).

BANZATTO, D.A.; KRONKA, S.N. Experimentação agrícola. Jaboticabal: FUNEP, 1989. $247 \mathrm{p}$.

BALKS, M.R.; BOND, W.J.; SMITH, C.J. Effects of sodium accumulation on soil physical properties under an effluent-irrigated plantation. Australian Journal of Soil Research, v.36, p.821-830, 1998.

BIELORAI, H.; VAISMAN, I.; FEIGIN, A. Drip irrigation of cotton with treated municipal effluents: I. Yield response. Journal of Environmental Quality, v.13, p.231-234, 1984.

BIGERIEGO, M.; HAUCK, R.D.; OLSON, R.A. Uptake, translocation and utilization of ${ }^{15} \mathrm{~N}$-depleted fertilizer in irrigated corn. Soil Science Society of America Journal, v.43, p.528-533, 1979.

BOLAN, N.S; HEDLEY, M.J.; WHITE, R.E. Processes of soil acidification during nitrogen cycling with emphasis on legume based pastures. Plant and Soil, v.134, p.53-63, 1991.

BOLAN, N.S; NAIDU, R.; SYERS, J.K.; TILLMAN, R.W. Surface charge and solute interactions in soils. Advances in Agronomy, v.67, p.87-140, 1999.

BOLE, J.B.; BELL, R.G. Land application of municipal sewage waste water: yield and chemical composition of forage crops. Journal of Environmental Quality, v.7, p.222-226, 1978.

BOND, W.J. Effluent irrigation - an environmental challenge for soil science. Australian Journal of Soil Research, v.36, p.543-555, 1998.

BORKERT, C.M. Manganês. In: FERREIRA, M.E.; CRUZ, M.C.P. (Ed.) Micronutrientes na agricultura. Piracicaba: Potafos/CNPq, 1991. p.173-190.

BOUWER, H. Integrated water management: emerging issues and challenges. Agricultural Water Management, v.45, p.217-228, 2000. 
BOUWER, H.; CHANEY, R.L. Land treatment of wastewater. Advances in Agronomy, v.26, p.133-176, 1974.

BOUWER, H.; IDELOVITCH, E. Quality requirements for irrigation with sewage water. Journal of Irrigation and Drainage Engineering, v.113, p.516-535, 1987.

BURAU, R.G.; SHEIKH, B.; CORT, R.P.; COOPER, R.C.; RIRIE, D. Reclaimed water for irrigation of vegetables eaten raw. California Agriculture, v.41, p.4-7, 1987.

CAMARGO, O.A.; MONIZ, A.C.; JORGE, J.A.; VALADARES, J.M.A.S. Métodos de análise química, mineralógica e física de solos do Instituto Agronômico de Campinas. Campinas: Instituto Agronômico, 1986. 94p. (Boletim Técnico, 106).

CAMERON, K.C.; DI, H.J.; McLAREN, R.G. Is soil an appropriate dumping ground for our wastes? Australian Journal of Soil Research, v.35, p.995-1035, 1997.

CHAE, Y.M.; TABATABAI, M.A. Mineralization of nitrogen in soils amended with organic wastes. Journal of Environmental Quality, v.15, p.193-198, 1986.

COMPANHIA ESTADUAL DE TECNOLOGIA DE SANEAMENTO AMBIENTAL. Aplicação de lodos de sistemas de tratamento biológico em áreas agrícolas critérios para projeto e operação: manual técnico. São Paulo, 1999. 32p.

CROMER, R.N.; TOMPKINS, D.; BARR, N.J.; HOPMANS, P. Irrigation of Monterey pine with wastewater: effect on soil chemistry and groundwater composition. Journal of Environmental Quality, v.13, p.539-542, 1984.

DARWISH, M.R.; EL-AWAR, F.A.; SHARARA, M.; HAMDAR, B. Economicenvironmental approach for optimum wastewater utilization in irrigation: a case study in Lebanon. Applied Engineering in Agriculture, v.15, p.41-48, 1999.

DAY, A.D.; TUCKER, T.C. Production of small grains pasture forage using sewage effluent as a source of irrigation water and plant nutrients. Agronomy Journal, v.51, p.569-572, 1959.

DAY, A.D.; TUCKER, T.C. Hay production of small grains utilizing city sewage effluent. Agronomy Journal, v.52, p.238-239, 1960.

DAY, A.D.; TUCKER, T.C. Effects of treated municipal waste water on growth, fiber, protein, and amino acid content of sorghum grain. Journal of Environmental Quality, v.6, p.325-327, 1977. 
DAY, A.D.; DICKSON, A.D.; TUCKER, T.C. Effect of city sewage effluent on grain yield and grain and malt quality of fall-sown, irrigated barley. Agronomy Journal, v.55, p.317-318, 1963.

DAY, A.D.; MCFADYEN, J.A.; TUCKER,T.C.; CLUFF, C.B. Commercial production of wheat grain irrigated with municipal waste water and pump water. Journal of Environmental Quality, v.8, p.403-406, 1979.

DAY, A.D.; McFADYEN, J.A.; TUCKER,T.C.; CLUFF, C.B. Effects of municipal waste water on the yield and quality of cotton. Journal of Environmental Quality, v.10, p.47-49, 1981.

DAY, A.D.; RAHMAN, A., KATTERMAN, F.R.H.; JENSEN, V. Effects of treated municipal wastewater and commercial fertilizer on growth, fiber, acid-soluble nucleotides, protein, and amino acid content in wheat hay. Journal of Environmental Quality, v.3, p.17-19, 1974.

DAY, A.D.; SWINGLE, R.S.; TUCKER, T.C.; CLUFF, C.B. Alfalfa hay grown with municipal waste water and pump water. Journal of Environmental Quality, v.11, p.23-24, 1982.

DAY, A.D. TAHER, F.A.; KATTERMAN, F.R.H. Influence of treated municipal waste water on growth, fiber, acid-soluble nucleotides, protein, and amino acid content in wheat grain. Journal of Environmental Quality, v.4, p.167-169, 1975.

DAY, A.D.; TUCKER, T.C.; VAVICH, M.G. Effect of city sewage effluent on the yield and quality of grain from barley, oats, and wheat. Agronomy Journal, v.54, p.133-135, 1962.

DORICH, R.A.; NELSON, D.W.; SOMMERS, L.E. Algal availability of phosphorus in suspended stream sediments of varying particle size. Journal of Environmental Quality, v.13, p.82-86, 1984.

EMPRESA BRASILEIRA DE PESQUISA AGROPECUÁRIA. Manual de métodos de análise de solo. 2.ed. Rio de Janeiro: CNPS, 1997. 212p.

FALKINER, R.A.; POLGLASE, P.J. Transport of phosphorus through soil in an effluent-irrigated tree plantation. Australian Journal of Soil Research, v.35, p.385-397, 1997. 
FALKINER, R.A.; SMITH, C.J. Changes in soil chemistry in effluent-irrigated Pinus radiata and Eucalyptus grandis. Australian Journal of Soil Research, v.35, p.131-147, 1997.

FASSBENDER, H.W.; BORNEMISZA, E. Química de suelos con énfasis en suelos de América Latina. 2.ed. San José: IICA, 1987. 420p.

FEIGIN, A.; FEIGENBAUM, S.; LIMONI, H. Utilization efficiency of nitrogen from sewage effluent and fertilizer applied to corn plants growing in a clay soil. Journal of Environmental Quality, v.10, p.284-287, 1981.

FEIGIN, A.; RAVINA, I.; SHALHEVET, J. Irrigation with treated sewage effluent: management for environmental protection. Berlin: Springer-Verlag, 1991. 224p.

FEIGIN, A.; VAISMAN, I.; BIELORAI, H. Drip irrigation of cotton with treated municipal effluents: II. Nutrient availability in soil. Journal of Environmental Quality, v.13, p.234-238, 1984.

FEIGIN, A.; BIELORAI, H.; DAG, Y.; KIPNIS, T.; GISKIN, M. The nitrogen factor in the management of effluent-irrigated soils. Soil Science, v.125, p.248-254, 1978.

FITZPATRICK, G.; DONSELMAN, H.; CARTER, N.S. Interactive effects of sewage effluent irrigation and supplemental fertilization on container-grown trees. HortScience, v.21, p.92-93, 1986.

FLORES TENA, F.J.; MUÑOZ SALAS, E.M.; MORQUECHO BUENDÍA, O. Absorcion de cromo y plomo por alfalfa y pasto ovillo. Agrociencia, v.33, p.381388, 1999.

FRIEDEL, J.K.; LANGER, T.; SIEBE, C.; STAHR, K. Effects of long-term waste water irrigation on soil organic matter, soil microbial biomass and its activities in central Mexico. Biology and Fertility Soils, v.31, p.414-421, 2000.

GADALLAH, M.A.A. Effects of industrial and sewage waste water on the concentration of soluble carbon, nitrogen, and some mineral elements in sunflower plants. Journal of Plant Nutrition, v.17, p.1369-1384, 1994.

GOH, K.M.; CONDRON, L.M. Plant availability of phosphorus accumulated from long-term applications of superphosphate and effluent to irrigated pastures. New Zealand of Agricultural Research, v.32, p.45-51, 1989. 
GONÇALVES, J.L.M.; STAPE, J.L.; BENEDETTI, V.; FESSEL, V.A.G.; GAVA, J.L. Reflexos do cultivo mínimo e intensivo do solo em sua fertilidade e na nutrição das árvores. In: GONÇALVES, J.L.M.; BENEDETTI, V. (Ed.) Nutrição e fertilização florestal. Piracicaba: IPEF, 2000. p.1-57.

GRIFFIN, R.A.; JURINAK, J.J. Estimation of activity coefficients from the electrical conductivity of natural aquatic systems and soil extracts. Soil Science, v.152, p.2630, 1973.

HALL, S.J.; MATSON, P.A. Nitrogen oxide emissions after additions in tropical forests. Nature, v.400, p.152-155, 1999.

HOOK, J.E. Movement of phosphorus and nitrogen in soil following application of municipal wastewater. In: NELSON, D.W.; ELRICK, D.E.; TANJI, K.K. (Ed.) Chemical mobility and reactivity in soil systems. Madison: Soil Science Society of America, 1981. p.241-255.

HOOK, J.E.; KARDOS, L.T. Nitrate leaching during long-term spray irrigation for treatment of secondary sewage effluent on woodland sites. Journal of Environmental Quality, v.7, p.30-34, 1978.

HORTENSTINE, C.C. Chemical changes in the soil solution from a Spodosol irrigated with secondary-treated sewage effluent. Journal of Environmental Quality, v.5, p.335-338, 1976.

HUSSAIN, G.; AL-JALOUD, A.A. Effect of irrigation and nitrogen on yield, yield components and water use efficiency of barley in Saudi Arabia. Agricultural Water Management, v.36, p.55-70, 1998.

HUSSAIN, G.; AL-JALOUD, A.A.; KARIMULLA, S. Effect of treated effluent irrigation and nitrogen on yield and nitrogen use efficiency of wheat. Agricultural Water Management, v.30, p.175-184, 1996.

INGLÉS, A.; GÓMEZ, M.; NOGALES, R. Efecto del riego con aguas residuales urbanas depuradas sobre la disponibilidad de metales pesados para la planta. Suelo y Planta, v.2, p.703-712, 1992.

JANSSEN, B.H. Nitrogen mineralization in relation to $\mathrm{C}: \mathrm{N}$ ratio and decomposability of organic materials. Plant and Soil, v.181, p.39-45, 1996. 
JEYARAMAN, S. Influence of $\mathrm{N}$ levels of crude protein yield of hybrid napier under sewage effluent irrigation. Indian Journal of Agronomy, v.33, p.326-327, 1988.

JOHNS, G.G.; McCONCHIE, D.M. Irrigation of bananas with secondary treated sewage effluent. I. Field evaluation of effect on plant nutrients and additional elements in leaf, pulp and soil. Australian Journal of Agricultural Research, v.45, p.1601-1617, 1994a.

JOHNS, G.G.; McCONCHIE, D.M. Irrigation of bananas with secondary treated sewage effluent. II. Effect on plant nutrients, additional elements and pesticide residues in plants, soil and leachate using drainage lysimeters. Australian Journal of Agricultural Research, v.45, p.1619-1638, 1994b.

JORDAN, M.J.; NADELHOFFER, K.J.; FRY, B. Nitrogen cycling in forest and grass ecosystems irrigated with ${ }^{15} \mathrm{~N}$-enriched wastewater. Ecological Applications, v.7, p.864-881, 1997.

KARDOS, L.T.; HOOK, J.E. Phosphorus balance in sewage effluent treated soils. Journal of Environmental Quality, v.5, p.87-90, 1976.

KARLEN, D.L.; VITOSH, M.L.; KUNZE, R.J. Irrigation of corn with simulated municipal sewage effluent. Journal of Environmental Quality, v.5, p.269-273, 1976.

KIEHL, E.J. Fertilizantes orgânicos. São Paulo: Agronômica Ceres, 1985. 492p.

LATTERELL, J.J.; DOWDY, R.H.; CLAPP, C.E.; LARSON, W.E.; LINDEN, D.R. Distribution of phosphorus in soils irrigated with municipal waste-water effluent: a 5-year study. Journal of Environmental Quality, v.11, p.124-128, 1982.

LÉON SUEMATSU, G.; MOSCOSO CAVALLINI, J. Tratamento e uso de águas residuárias. Campina Grande: UFPA, 1999. 109p.

LINDEN, D.R.; CLAPP, C.E.; GILLEY, J.R. Effects of scheduling municipal wastewater effluent irrigation of reed canarygrass on nitrogen renovation and grass production. Journal of Environmental Quality, v.10, p.507-510, 1981.

LUND, L.J. Nitrogen balance in a pond system receiving tertiary effluent. Journal of Environmental Quality, v.28, p.1258-1263, 1999. 
LUND, L.J.; PAGE, A.L.; NELSON, C.O.; ELLIOTT, R.A. Nitrogen balances for an effluent irrigation area. Journal of Environmental Quality, v.10, p.349-352, 1981.

LURIE, S.; ZILKAH, S.; DAVID, I.; LAPSKER, Z.; ARIE, R.B. Quality of "Flamekist" nectarine fruits from on orchard irrigated with reclaimed sewage water. Journal of Horticultural Science, v.71, p.313-319, 1996.

LYNCH, J.; CRAMER, G.R.; LÄUCHLI, A. Salinity reduces membrane-associated calcium in corn root protoplasts. Plant Physiology, v.83, p.390-394, 1987.

MAGESAN, G.N.; MCLAY, C.D.A.; LAL, V.V. Nitrate leaching from a free-draining volcanic soil irrigated with municipal sewage effluent in New Zealand. Agriculture, Ecosystems and Environment, v.70, p.181-187, 1998.

MALAVOLTA, E. Elementos da nutrição mineral de plantas. São Paulo: Ceres, 1980. 251p.

MALAVOLTA, E.; VITTI, G.C.; OLIVEIRA, S.A. Avaliação do estado nutricional das plantas: princípios e aplicações. 2.ed. Piracicaba: Potafos, 1997. 319p.

MARTIN, J.P.; RICHARDS, S.J.; PRATT, P.F. Relationship of exchangeable Na percentage at different soil $\mathrm{pH}$ levels to hydraulic conductivity. Soil Science Society America of Proceedings, v.28, p.620-622, 1964.

MATSON, P.A.; NAYLOR, R.; ORTIZ-MONASTERIO, I. Integration of environmental, agronomic, and economic aspects of fertilizer management. Science, v.280, p.112-115, 1998.

MAURER, M.A.; DAVIES, F.S. Microsprinkler irrigation of young "Redblush" grapefruit trees using reclaimed water. HortScience, v. 28, p.1157-1161, 1993.

McBRIDE, M.B. Reactions controlling heavy metal solubility in soils. Advances in Soil Science, v.10, p.1-57, 1989.

MELFI, A.J.; PEDRO, G. Estudo geoquímico dos solos e formações superficiais do Brasil. Parte I. Caracterização e repartição dos principais tipos de evolução pedogeoquímica. Revista Brasileira de Geociências, v.7, p.271-286, 1977. 
MELFI, A.J.; PEDRO, G. Estudo geoquímico dos solos e formações superficiais do Brasil. Parte II. Considerações sobre os mecanismos geoquímicos envolvidos na alteração superficial e sua repartição no Brasil. Revista Brasileira de Geociências, v.8, p.11-22, 1978.

MELFI, A.J.; PEDRO, G.; VOLKOFF, B. Natureza e distribuição dos compostos ferríferos nos solos do Brasil. Revista Brasileira de Ciência do Solo, v.3, p.47-54, 1979.

MENGEL, K. Turnover of organic nitrogen in soils and its availability to crops. Plant and Soil, v.181, p.83-93, 1996.

MENGEL, K.; KIRKBY, E.A. Principles of plant nutrition. 4.ed. Bern: International Potash Institute, 1987. 687p.

MYERS, R.J.K.; CAMPBELL, C.A.; WEIER, K.L. Quantitative relationship between net nitrogen mineralization and moisture content of soils. Canadian Journal of Soil Science, v.62, p.111-124, 1982.

MUJERIEGO, R.; SALA, L.; CARBÓ, M.; TURET, J. Agronomic and public health assessment of reclaimed water quality for landscape irrigation. Water Science $\&$ Technology, v.33, p.335-344, 1996.

OLMOS, J.L.J.; CAMARGO, M.N. Ocorrência de alumínio tóxico nos solos do Brasil, sua caracterização e distribuição. Ciência e Cultura, v.28, p.171-180, 1979.

ORON, G.; CAMPOS, C.; GILLERMAN, L.; SALGOT, M. Wastewater treatment, renovation and reuse for agricultural irrigation in small communities. Agricultural Water Management, v.38, p.223-234, 1999.

OVERMAN, A.R. Irrigation of corn with municipal effluent. Transactions of the American Society of Agricultural Engineers, v.24, p.74-80, 1981.

OVERMAN, A.R.; NGUY, A. Growth response and nutrient uptake by forage crops under effluent irrigation. Communication in Soil Science and Plant Analysis, v.6, p.81-93, 1975.

OVERMAN, A.R.; WILSON, D.M.; VIDAK, W.; ALLHANDS, M.N.; PERRY JR., T.C. Model for partitioning of dry matter and nutrients in corn. Journal of Plant Nutrition, v.18, p.959-968, 1995. 
PAGANINI, W.S. Disposição de esgotos no solo: escoamento à superfície. 2.ed. São Paulo: Fundo Editorial da AESABESP, 1997. 232p.

PESCOD, M.B. Wastewater treatment and use in agriculture. Rome: FAO, 1992. 125p. (Irrigation and Drainage Paper, 47).

POLGLASE, P.J.; TOMPKINS, D.; STEWART, L.G.; FALKINER, R.A. Mineralization and leaching of nitrogen in an effluent-irrigated pine plantation. Journal of Environmental Quality, v.24, p.911-920, 1995.

PÖTTKER, D.; TEDESCO, M.J. Efeito do tipo e tempo de incubação sobre a mineralização da matéria orgânica e nitrogênio total em solos do Rio Grande do Sul. Revista Brasileira de Ciência do Solo, v.3, p.20-24, 1979.

QUIN, B.F. Irrigation with sewage effluent. New Zealand Journal of Agriculture, v.5, p.30-32, 1978.

QUIN, B.F.; FORSYTHE, L.J. Surface irrigation of pasture with treated sewage effluent. II. Drainage losses of nitrate and other nutrients. New Zealand Journal of Agricultural Research, v.21, p.427-434, 1978.

QUIN, B.F.; SYERS, J.K. Surface irrigation of pasture with treated sewage effluent. III. Heavy metal content of sewage effluent, sludge, soil, and pasture. New Zealand Journal of Agricultural Research, v.21, p.435-442, 1978.

QUIN, B.F.; WOODS, P.H. Surface irrigation of pasture with treated sewage effluent. I. Nutrient status of soil and pastures. New Zealand Journal of Agricultural Research, v.21, p.419-426, 1978.

RAIJ, B.van. Determinação de cargas elétricas em solos. Bragantia, v.32, p.171-183, 1973.

RAIJ, B.van. Gesso agrícola na melhoria do ambiente radicular no subsolo. São Paulo: ANDA, 1988. 88p.

RAIJ, B.van. Fertilidade do solo e adubação. Piracicaba: Potafos, 1991. 343p.

RAIJ, B.van; CANTARELlA, H.; QUAGGIO, J.A.; FURLANI, A.M.C. (Ed.). Recomendações de adubação e calagem para o Estado de São Paulo. 2.ed. Campinas: Instituto Agronômico, 1996. 285p. (Boletim Técnico, 100). 
RUZICKA, J.; HANSEN, E.H. Flow injection analysis. Part I. The concept of a new, simple, ultrafast continuous flow analyzer. Analytical Chemistry Acta, v.78, p.145-157, 1975.

SCHALSCHA, E.B.; VERGARA, I; SCHIRADO, T.; MORALES, M. Nitrate movement in a Chilean agricultural area irrigated with untreated sewage water. Journal of Environmental Quality, v.8, p.27-30, 1979.

SCHIPPER, L.A.; WILLIAMSON, J.C.; KETTLES, H.A; SPEIR, T.W. Impact of landapplied tertiary-treated effluent on soil biochemical properties. Journal of Environmental Quality, v.25, p.1073-1077, 1996.

SEGARRA, E.; DARWISH, M.R.; ETHRIDGE, D.E. Returns to municipalities from integrating crop production with wastewater disposal. Resources, Conservation \& Recycling, v.17, p.97-107, 1996.

SHUVAL, H.L.; ADIN, A.; FATTAL, B.; RAWITZ, E.; YEKUTIEL, P. Wastewater irrigation in developing countries: health effects and technical solutions. Washington: The Wold Bank, 1986.

SIMS, R.E.H. Utilization of waste organic matter. Agriculture, Ecosystems and Environment, v.58, p.91-95, 1996.

SMITH, C.J.; BOND, W.J. Losses of nitrogen from an effluent-irrigated plantation. Australian Journal of Soil Research, v.37, p.371-389, 1999.

SMITH, C.J.; FRENEY, J.R.; BOND, W.J. Ammonia volatilization from soil irrigated with urban sewage effluent. Australian Journal of Soil Research, v.34, p.789802, 1996a.

SMITH, C.J.; HOPMANS, P.; COOK, F.J. Accumulation of $\mathrm{Cr}, \mathrm{Pb}, \mathrm{Cu}, \mathrm{Ni}, \mathrm{Zn}$ and $\mathrm{Cd}$ in soil following irrigation with treated urban effluent in Australia. Environmental Pollution, v.94, p.317-323, 1996 b.

SNOW, V.O.; SMITH, C.J.; POLGLASE, P.J.; PROBERT, M.E. Nitrogen dynamics in a eucalypt plantation irrigated with sewage effluent or bore water. Australian Journal of Soil Research, v.37, p.527-544, 1999. 
SPEIR, T.W.; VAN SCHAIK, A.P.; KETTLES, H.A.; VICENT, K.W.; CAMPBELL, D.J. Soil and stream-water impacts of sewage effluent irrigation onto steeply sloping land. Journal of Environmental Quality, v.28, p.1105-1114, 1999.

STANFORD, G.; EPSTEIN, E. Nitrogen mineralization-water relations in soils. Soil Science Society of America Proceedings, v.38, p.99-102, 1974.

STANFORD, G.; SMITH, S.J. Nitrogen mineralization potentials of soils. Soil Science Society of America Proceedings, v.36, p.465-472, 1972.

STEVENSON, F.J. Origin and distribution of nitrogen in soil. In: STEVENSON, F.J. (Ed.) Nitrogen in agricultural soils. 2.ed. Madison: ASA, CSSA, SSSA, 1985. p.1-42.

STEWART, H.T.L.; HOPMANS, P.; FLINN, D.W. Nutrient accumulation in trees and soil following irrigation with municipal effluent in Australia. Environmental Pollution, v.63, p.155-177, 1990.

TANJI, K.K. Irrigation with marginal quality waters: issues. Journal of Irrigation and Drainage Engineering, v.123, p.165-169, 1997.

TISDALE, S.L.; NELSON, W.L.; BEATON, J.D. Soil fertility and fertilizers. 4.ed. New York: Macmillan, 1985. 754p.

VAISMAN, I.; SHALHEVET, J.; KIPNIS, T.; FEIGIN, A. Reducing ground-water pollution from municipal waste-water irrigation of Rhodes grass grown on sand dunes. Journal of Environmental Quality, v.10, p.434-439, 1981.

VAN ENGERS, L. Mineralization of organic matter in the subsoil of a waste disposal site: a laboratory experiment. Soil Science, v.126, p.22-28, 1978.

VAZQUEZ-MONTIEL, O.; HORAN, N.J.; MARA, D.D. Management of domestic wastewater for reuse in irrigation. Water Science \& Technology, v.33, p.355-362, 1996.

YAN, F.; SCHUBERT, S.; MENGEL, K. Soil pH increase due to biological descarboxilation of organic anions. Soil Biology \& Biochemistry, v.28, p.617-624, 1996. 